\title{
Aukcióelmélet előadások
}

„Ha eladsz vagy veszel ...,

ne csapd be testvéredet." (Lev 25,14)

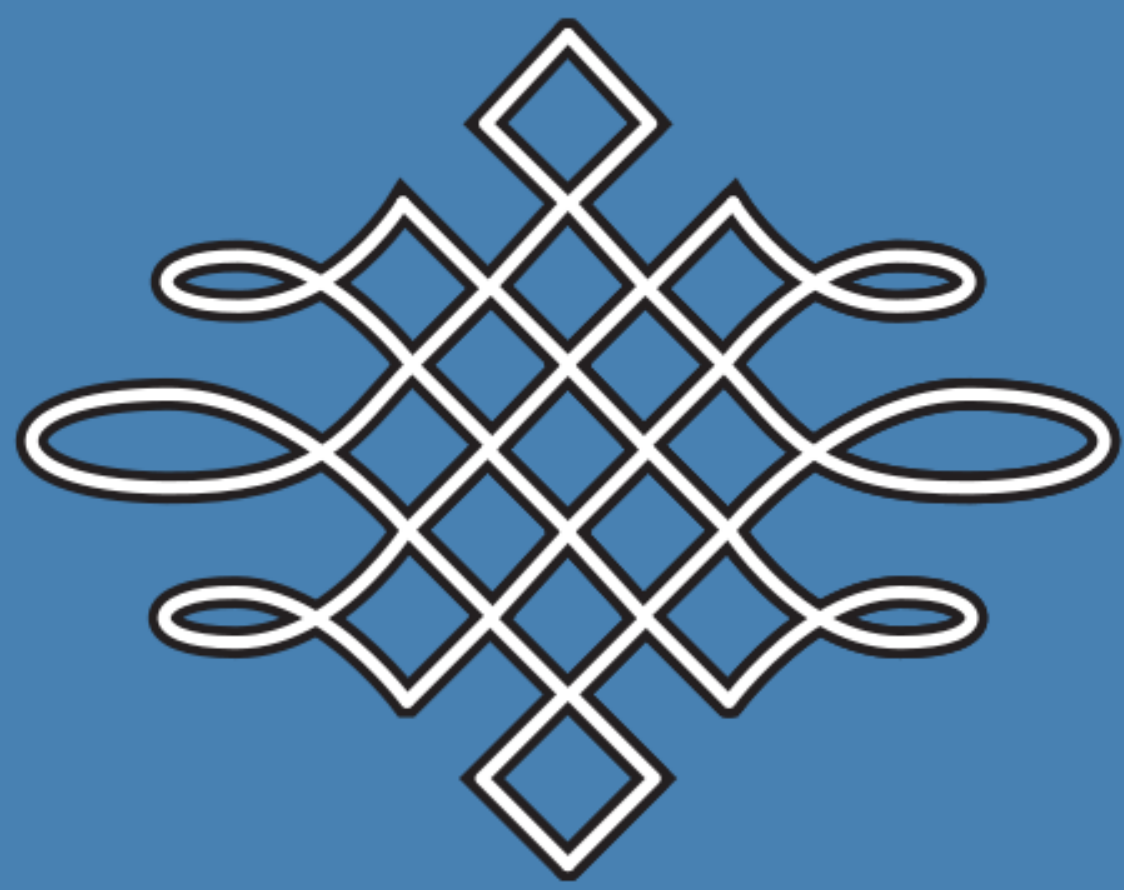

Szerző: MAGYARKUTI GYULA

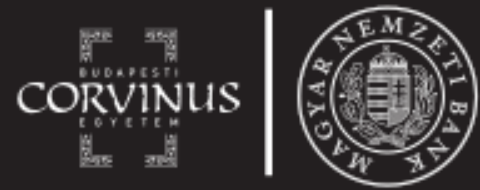




\section{Aukcióelmélet előadások}

Budapest I 2018. 



\section{Magyarkuti Gyula}

\section{Aukcióelmélet előadások}

Közgazdaságtudományi Kar

Matematika Tanszék 
Budapesti Corvinus Egyetem

Közgazdaságtudományi Kar

Matematika Tanszék

Cím:

Aukcióelmélet előadások

Szerzó:

(C) Magyarkuti Gyula

\section{Kiadó:}

Budapesti Corvinus Egyetem I 1093, Budapest, Fővám tér 8.

\section{Nyomdai kivitelezés:}

Komáromi Nyomda

ISBN 978-963-503-705-6, 978-963-503-709-4 (ebook)

DOI $10.14267 / \mathrm{cb} .2018 \mathrm{k} 02$

Budapest I 2018.

„A Budapesti Corvinus Egyetem és a Magyar Nemzeti Bank együttmúködési megállapodása keretében támogatott mú.”
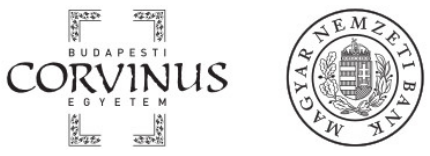


\section{TARTALOM}

\begin{tabular}{ll}
\hline Elószó & 7
\end{tabular}

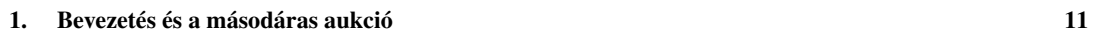

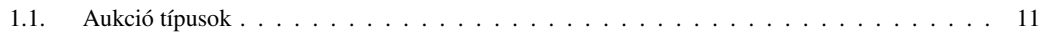

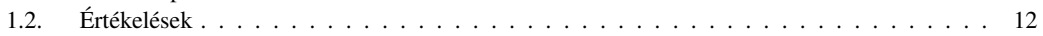

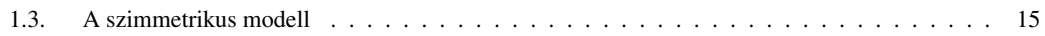

$1.4 . \quad$ Másodáras aukció $\ldots \ldots \ldots \ldots \ldots$. . . . . . . . . . . . . . . . . . . 19

\begin{tabular}{lr}
\hline 2. Elsóáras aukció & 25
\end{tabular}

\begin{tabular}{|lr}
\hline 3. Elsố- és másodáras aukció rezervációs árral & 33 \\
\hline
\end{tabular}

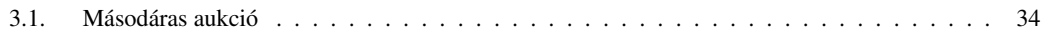

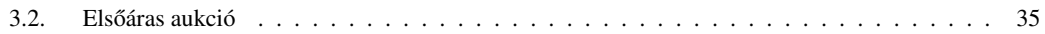

\begin{tabular}{lll}
\hline $4 . \quad$ Virtuális értékelés & 41
\end{tabular}

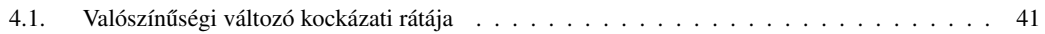

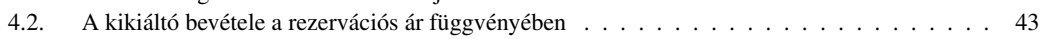

$4.3 . \quad$ A kikiáltó mint monopolista $\ldots \ldots \ldots \ldots$. . . . . . . . . . . . . . . . . 46

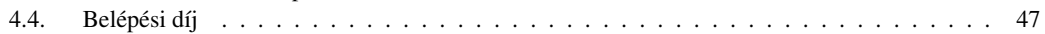

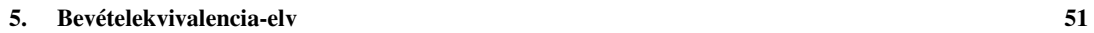

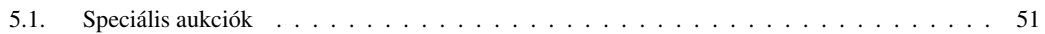

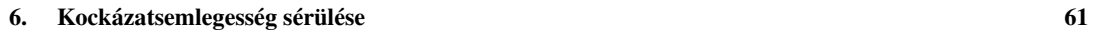

\begin{tabular}{lll}
\hline 7. A szimmetrikus értékelés sérülése & 67
\end{tabular}

7.1. Egyenletes eloszlások esete . . . . . . . . . . . . . . . . . . . . . . . 69

7.2. Első- és másodáras bevételek összehasonlítása $\ldots \ldots \ldots \ldots \ldots$. . . . . . . . 73

\begin{tabular}{lcr}
\hline 8. & Erốszakos licitáló & 77
\end{tabular}

\begin{tabular}{llr|}
\hline 9. Aukció mint mechanizmus & 83
\end{tabular}

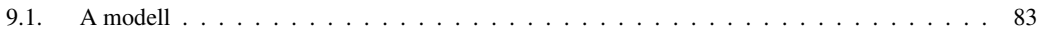

$9.2 . \quad$ Mechanizmus . . . . . . . . . . . . . . . . . . . . . . 84

9.3. Revelációs elv . . . . . . . . . . . . . . . . . . . . . . . . . . . . . . . . . . 87

10. Ösztönzố mechanizmus 91

10.1. Az ösztönző mechanizmus definíciója. . . . . . . . . . . . . . . . . . . . . . . 91 
10.2. Kapcsolat a bevételekvivalencia-elvvel . . . . . . . . . . . . . . . . . . . 92

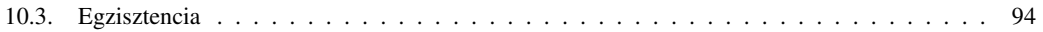

10.4. A kikiáltó bevétele . . . . . . . . . . . . . . . . . . . . . . . . 96

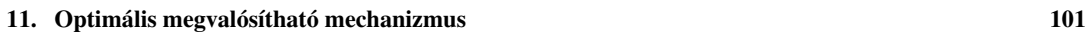

11.1. Megvalósítható direkt-mechanizmus . . . . . . . . . . . . . . . . . . . 101

11.2. Példa a kikiáltó számára maximális bevételt adó megvalósítható mechanizmusra . . . . . . . 102

11.3. Az optimális megvalósítható mechanizmus interpretációi _ . . . . . . . . . . . . . 105

12. VCG-mechanizmus 109

12.1. Hatékony allokáció . . . . . . . . . . . . . . . . . . . . . . . . 109

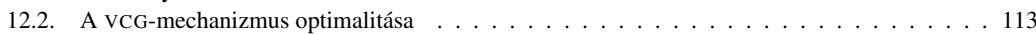

12.3. A vCG-befizetési szabály értelmezése . . . . . . . . . . . . . . . . . . . . . . . . 117

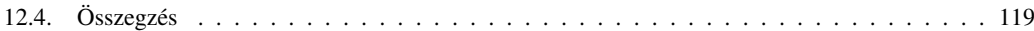

\begin{tabular}{|rr}
\hline Függelék & 121
\end{tabular}

\begin{tabular}{|l|l|l|l}
\hline A. Valós konvex függvények & 125 \\
\hline
\end{tabular}

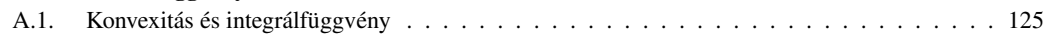

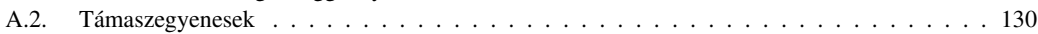

\begin{tabular}{ll}
\hline Irodalomjegyzék & 135
\end{tabular}

$\begin{array}{ll}\text { Tárgymutató } & 139\end{array}$ 


\section{Előszó}

AZ ELŐADÁSJEGYZET A Budapesti Corvinus Egyetem Matematika Tanszékének Aukcióelmélet címû kurzusához készült. A jegyzet alapja Vijay Krishna Auction Theory címú könyve [19]. Azért választottam ezt a múvet az előadásaim alapjául, mert olyan bevezető jellegú könyvet kerestem, amely

a) rigorózus matematikai megközelítést használ,

b) de naiv valószínúségszámítási ismeretekkel is feldolgozható,

c) ugyanekkor illeszkedik az Aukcióelmélet oktatásának nemzetközi standardjához.

E könyv pontosan tükrözi az általam tartott Aukcióelmélet címú tárgy tanmenetét. Egy szemeszterben 12 hetet feltételezve, az itteni 12 fejezet a szemeszter egy-egy hetének feleltethetố meg, szigorúan a fejezetek sorrendjében haladva.

Az anyag megértéséhez szükséges előismeretek a következők: Analízis, a szokásos integrál- és differenciálszámítás (pl.: [5]); Valószínűségszámítás, de elegendő a Mértékelmélet nélküli, ú.n. naív tárgyalás (pl.:[27]); Mikroökonómia, itt is elegendô a belépő szint (pl.:[41]), de különösen fontos a Nash-egyensúly koncepciójának pontos értelmezése. Az anyag mélyebb megértéséhez nélkülözhetetlen a Mértékelméleti megalapozás (pl.:[23]), és a haladó Mikroökonómiai tárgyalás (pl.:[4],[25]), de ezek nélkül is belevághatunk az aukcióelmélet rejtelmeinek megismerésébe, itt értem ezalatt: e könyv olvasásába. Ez esetben e könyv szolgáltat majd motivációt a fenti diszciplínákkal való ismerkedésre.

Egyéni tanulásra, a kutatások megkezdésére, esetlegesen szakdolgozathoz vagy TDK munkához itt szeretnék további dolgozatokat ajánlani. Fejezetenkénti bontásban tehát:

1-4. fejezetekhez: [39], [2], [3], [8], [6],[40], [30].

5. fejezethez: [22], [1].

6-8. fejezetekhez: [9], [10], [12], [13], [17], [37].

9-12. fejezetkehez: [7], [11], [32], [33], [36], [31], [24].

Köszönetemet fejezem ki Pálvölgyi Dénes tanár úrnak, aki idejét nem kímélve, majd egy szemeszteren keresztül, hosszan diszkutálta velem az anyag jelentős részét. Azok a 
hibák, amik ennek ellenére a könyvben maradtak egyedül engem terhelnek. Az oktatás során felszínre kerülő félreértéseket, elírásokat, hibákat igyekszem kijavítani a könyv elektronikus verziójában. Örömmel fogadom az olvasó által talált hibákat. Az elektronikus verzió a honlapomról (http://web.uni-corvinus.hu/magyarkuti) elérhető. Ajánlom az ottani példány használatát.

Köszönettel tartozom Vijay Krishnának a személyes segítségért, és az ELSEVIER kiadónak, hogy támogatta a könyv megjelenését. Köszönöm a kar és az egyetem vezetésének a tankönyv megírásához nyújtott anyagi támogatást. Köszönettel gondolok a Matematika tanszék tagjaira, akik hosszú távon támogatták munkámat. Különösen is szeretném megköszönni a péntek délutáni tanszéki szemináriumok résztvevőinek idejét, kitartását, türelmét, figyelmét és fegyelmét, az évek óta tartó sokoldalú személyes támogatását.

Végül szeretettel ajánlom e könyvet volt és leendő hallgatóimnak, abban bízva, hogy ugyanolyan örömmel olvassák majd, ahogyan én írtam.

Budapest, 2018. nyarán

Magyarkuti Gyula 


\section{BEVEZETÉS ÉS A MÁSODÁRAS AUKCIÓ}



AZ AUKCIÓK LEBONYOLÍTÁSI formáinak közös jellemzője, hogy összesen két dolgot garantálnak:

1. Kiválasztják a résztvevőł 1 közül azt a játékost, aki elnyeri az aukció tárgyát. Ez a játékos az aukció nyertese.

2. Megadják a résztvevők fizetési kötelezettségét. Miután kiderült, hogy ki a fenti pont szerinti nyertes, résztvevőnként külön-külön meghatározzák a fizetési kötelezettségeket ${ }^{2}$

A játékosok az aukcióban való részvételükkel elfogadják, hogy az előttük előre ismert lebonyolítási rend majd a lejátszás után kiválasztja közülük a nyertest, és azt is elfogadják, hogy a lejátszás után befizetik a lebonyolítási rendben definiált, a lejátszásból adódó fizetési kötelezettségüket. Az aukció tárgya oszthatatlan, csak az egyik játékos birtokolhatja, a fizetési kötelezettség elől nem lehet kitérni.

Bármilyen típusú aukcióról is van szó, annak lehet egy rezervációs árat használó variánsa is. A rezervációs ár használata annyit tesz, hogy az aukció eredménytelen, ergo nincs nyertes, ha a fizetési kötelezettség nem éri el az előre meghatározott rezervációs árat. Ilyenkor senki nem nyeri el az aukciót tárgyát.

\subsection{Aukció típusok}

A matematikai formalizmus bevezetése felé haladva először összefoglaljuk a közismert aukció lebonyolítási formákat.

Angol aukció. A legismertebb és a legrégebben használt forma. Maga az aukció szó a köznyelvben sokszor az angol aukciót jelenti. Ennek oka, hogy a latin tô, az augere (emelkedô) is erre céloz. A kikiáltó bemond egy alacsony árat, ami mellett várhatóan több mint ketten megveszik a terméket, majd jellemzően kis lépésekben emeli az árat. Mindaddig emel az áron, amíg az árat elfogadó vevők száma nem kisebb mint 2. Ha egyetlen vevő marad, akkor övé a termék, azon az áron, amit a kikiáltó az utolsó alkalommal bemondott.

Az angol aukciót a következóképpen modellezhetjük: A teremben mindenki tudja, hogy mi az árverés tárgya. A potenciális vevők látják a pillanatnyi árat és kézfenntartással jelzik, ha azon az áron ők megvennék. Tegyük fel, hogy a kikiáltási ár 0-ról indul és folytonosan emelkedik. A kezdő pillanatban mindenkinek fent van a keze. Amint az ár olyan magas, hogy az aukció tárgyát a vevő azon az áron már nem venné meg, akkor leengedi a kezét. A játék addig folyik, amíg legalább két kéz van a magasban. Az aukciónak abban a pillanatban van vége, amikor egy kéz van csak felemelve, és az utolsó kéz tulajdonosa a nyertes. A nyertesnek az ebben a pillanatban érvényes árat

\footnotetext{
${ }^{1} \mathrm{~A}$ továbbiakban az aukció résztvevóje, a játékos, a licitáló egymás szinonimái.

${ }^{2}$ Ami persze - sokszor, de nem feltétlenül - nulla egy nem nyertes játékos esetén.
} 
kell megfizetnie. Az ár tehát a második legtöbbet ajánló résztvevő által éppen már nem elfogadott ár.

Holland aukció. Az angol aukcióval ellentétben az ár kis lépésekkel lefelé halad, olyan nagy összegrôl indulva, amit senki nem fogad el. A játék akkor ér véget, amikor az első érdeklődő jelzi vételi szándékát. Övé a termék, az éppen aktuális áron.

Zárt-ajánlatú elsőáras aukció. A résztvevők egymás ajánlatait nem ismerve ajánlatot tesznek a termékre. Mondjuk egy lezárt borítékban adják be az aukciót lebonyolítónak az ajánlatukat. Az nyeri az aukciót, aki a legmagasabb ajánlatot adja, az általa megajánlott áron.

Zárt-ajánlatú másodáras aukció. A résztvevők most is egymás ajánlatait nem ismerve tesznek ajánlatot a termékre. Az nyeri az aukciót, aki a legmagasabb ajánlatot adja, de nem az általa ajánlott, hanem a második legmagasabb ajánlott áron.

\section{2. Értékelések}

Ha elfogadjuk azt az alapfeltevést, hogy az általunk vizsgált jelenségeket nem a puszta véletlen, a vakszerencse hajtja, hanem a résztvevők gondolkodó lények és cselekedeteiket valamilyen fajta racionalitás vezérli, akkor az aukció résztvevőjének nyilvánvalóan kell valamilyen értékeléssel rendelkezni az aukció tárgyát illetően. Valami oka ugyanis van annak, hogy ott van a teremben, azaz részt vesz az aukcióban.

Az értékelés nehezen definiálható fogalom, de az intuitív tartalom szerint olyasmit fejezi ki, hogy a tárgy megszerzése a játékos számára mekkora többletet jelent. Hogy ez a többlet miben van kifejezve - egy érzelem teljesülése, esetleg egy pénzmennyiség, vagy egy szükséglet kielégítése - az a tárgyalásunk szintjén érdektelen. Az egyszerűség kedvéért képzelhetjük úgy, hogy ez az értékelés megadható egy számmal. Mintha a tárgy birtoklása a játékos számára $x$ bevételt jelentene, amikor is éppen $x$ az értékelése.

Fontos különbséget tennünk az értékelés és a licitálás közt. A licit az értékelésen alapul, de nem feltétlenül azonos avval. A licit mindig az az ár, amit az aukció lejátszása során a játékos a kikiáltóval közöl. Hogy a játékos az értékeléséból hogyan képzi a licitjét, az az ő dolga, és nagyon sok mindentől függ. Világos, hogy elsődlegesen az értékelésétôl, de függ például az aukció lebonyolítási formájától is. Emiatt mindig feltesszük, hogy az aukcióban résztvevő játékosok előtt tökéletesen ismert az aukció lebonyolítási módja, és az a tény is, hogy minden más résztvevő is rendelkezik evvel a tudással. Jegyzetünkben

$$
x \mapsto \beta(x)=b
$$

módon fejezzük ki az értékelés és a licitálás közti kapcsolatot. Ez azt jelenti, hogy ha egy bizonyos típusú aukcióban résztvevő játékosnak $x$ az értékelése, akkor ő ehhez az értékeléshez a $b=\beta(x)$ licitet társítja. A játékosok racionalitása azt jelenti, hogy a 
játékosok törekednek arra, hogy megtalálják azt a $\beta$ licitfüggvényt, ami az ô igényeiket a legjobban kielégíti. Hogy mit jelent ezen igények kielégítése, azt később pontosan formalizáljuk. (Nash-egyensúly.)

A holland aukcióban például mindenkinek van egy értékelése, ez alapján egy licitje, és akkor emeli fel a kezét, amikor az ő licitje a kijelzőn megjelenik. Az angol aukcióban akkor veszi le a kezét, amikor az ô általa még befizethető összeg eltűnik a kijelzőrôl. Ez volt az ô licitje. A zárt-ajánlatú elsô- vagy másodáras aukciókban a résztvevő́k ajánlatait gondolhatjuk az aukcióban résztvevők licitjeinek.

Az aukciónak éppen az az értelme, hogy amikor a kikiáltónak nincs elképzelése a játékosok értékeléséről, és jellemzően az aukció tárgyának értékéről sem, akkor valamilyen algoritmust adjon arra, hogy a tárgyat a kikiáltó valamilyen egyezség keretében, előre tisztázott szabályok közt, korrekt, hiteles módon tudja értékesíteni. A kikiáltónak nyilván a legnagyobb bevétel az érdeke. Ha tudná kinek a legmagasabb az értékelése, akkor egyszerúen az ezt képviselővel kötne üzletet. Hasonlóan, ha a kikiáltó biztosan tudná, hogy mekkora értékkel bír az árverés tárgya, nem kockáztatná az esetleg sokkal alacsonyabb árat. Gondoljunk például egy olajmező aukciójára. A gond éppen az, hogy senki nem tudja pontosan mennyi olajat rejt a föld, és rendkívül drága erről valami nagyon keveset is, de tudni. Ha a kikiáltó ezt tudná, semmi értelme nem lenne számára az olajmezô eladásának, egyszerúen ki tudná termelni, vagy éppen le tudna róla mondani.

A kérdés az, hogy mit teszünk fel ezen értékelések kialakulásáról. Mitôl függnek ezek az értékelések? Csak az árverés tárgyától, vagy esetleg függnek a játék többi résztvevôjének értékelésétől, mások véleményétől is?

\section{Magán értékelés}

Ha minden résztvevő a többiek befolyásától függetlenül tudja, hogy a termék számára mennyit ér az ajánlattevés pillanatában, akkor ezt az aukciót magán értékelésú aukciónak mondjuk. Implicit feltesszük, hogy senki nem tudja teljes bizonyossággal a másik résztvevő értékelését, mi több: ez senkit nem is érdekel. Ha az egyik résztvevő megtud valamit a másik értékelésérôl, az az ô értékelésére semmilyen hatással nincs, azaz a másik értékelésének ismerete nincs hatással a tárgy értékelésére.

Tipikusan magán értékelésú egy aukció, ha az eladandó objektum hasznossága pusztán annak elfogyasztásából ered. Például, ha bútorra vagy bélyegre gondolunk, akkor a magán értékelés azt tükrözi, hogy milyen hasznossága van számunkra a bútor bútorkénti, vagy a bélyeg bélyegkénti felhasználásának. Fontos látni, hogy ilyenkor is lehet ez az érték ajánlattevőnként nagyon különböző. Nem mindegy ugyanis, hogy mennyire fontos nekem a bélyeg felhasználása, azaz egy levél feladása. De gondolhatunk például arra is, hogy vizet árverezünk egy sivatagban szomjas emberek között. Ilyenkor a magán értékelés csak attól függ, hogy a játékos mennyire szomjas.

A fenti példánál sokkal életszerúbb, ezért sokkal szebb is, ha mobiltelefon szolgáltatók számára kiírt frekvencia aukciókra gondolunk. Viszonylag pontosan kiszámolható, 
hogy mondjuk a 800MHz-es frekvencia sáv kizárólagos birtoklása a szolgáltatási területen belül mekkora 4G adatforgalmat tesz lehetôvé az adott szolgáltató technikai felszereltségét figyelembe véve. Ezt az adott internet szolgáltató ismeri. Sốt csak ô ismeri. Összeveti a keresletre vonatkozó piaci kutatási eredményekkel, és így elég pontosan képes megbecsülni, hogy számára a 800MHz-es sáv birtoklása mekkora profittal járhat. Ez nagyjából független attól, hogy a konkurens szolgáltató mit gondol a dologról. Itt is teljesül tehát, hogy az aukció tárgyának hasznossága, annak „elfogyasztásából” ered, emiatt tekinthető a frekvencia aukció is egy magán értékelésű aukciónak.

Ha viszont a résztvevők értékelése nem csak a tárgytól, hanem mondjuk a tárgy másodlagos piacától is függ, olyan módon, hogy a vevő a tárgyat valamilyen befektetésnek tekinti, akkor az értékelés azonnal függ mások jövőbeni értékelésétől is, ami azt jelenti, hogy sérül a magán értékelés feltevése.

\section{Összefüggő értékelés}

Nagyon sok esetben az árverezendő objektum megnyerésének hasznossága teljesen ismeretlen, sốt megismerhetetlen az ajánlattevők számára. Természetesen lehetnek erről egyenkénti becsléseik, ezen becslések kialakítása azonban nagy erőfeszítésekbe kerülhet, tehát az információ a játék többi résztvevőjének értékeléséről hatással van az értékelések kialakítására.

Ugyanez a helyzet, ha a terméket másodlagos piacra szánjuk, hiszen ebben az esetben az én értékelésem mások jövőbeni értékelésének függvénye. Amikor az értékelés kialakítása függ az aukció többi résztvevőjének értékelésétől, akkor az aukciót összefüggó értékelésü aukciónak nevezzük.

Tipikusan összefüggő értékelésû aukció egy múalkotás aukciója, államkötvények aukciója, vagy egy olyan földterület árverése olajkitermelés céljából, amelyben a ténylegesen kitermelhető olaj mennyisége a résztvevő felek előtt ismeretlen.

\section{Ekvivalencia}

Képzeljük el, hogy egy magán értékelésű holland aukció előtt a résztvevők az általuk előre eldöntött árat egy lezárt borítékban küldik el a kikiáltónak. Világos, hogy a holland aukciót ugyanaz a személy nyeri és pontosan annyit fizet, mintha zárt-ajánlatú elsőáras aukciót játszanának le. Hasonlóképpen egy zárt-ajánlatú elsőáras aukciót lejátszhatunk holland aukcióként is. A nyertes személye és az árverés végső összege mindkét esetben azonos.

Azt azonban, hogy a két aukció lejátszási formája teljesen azonos lenne nem mondhatjuk ki. Ha holland aukcióként játsszuk le, akkor, amíg az aukció tart, mindenki tudja, hogy mindenkinek a licitje az aktuális árnál kisebb. Amikor véget ér a játék, akkor mindenki tudja kinek volt a legmagasabb a licitje. A kikiáltó számára csak az derül ki, hogy kié volt legnagyobb a licit. A többi licit pontos értéke a játék összes résztvevője előtt rejtve marad. 
Ha ugyanerre a jelenségre zárt-ajánlatú elsőáras aukcióként tekintünk, akkor majd az eredményhirdetés után derül ki kinek volt a legmagasabb a licitje. A kikiáltó számára minden licit kiderül. Ha magán értékelésrôl van szó, akkor a két lejátszásban rejlő információ különbség nem számít, hiszen ekkor az egyes játékosok értékelésére nincs hatással a másik értékelése.

Hasonló párhuzam vonható az angol aukció és a zárt-ajánlatú másodáras aukció között. Ha minden résztvevő előre eldönti, hogy milyen licitet alkalmaz, akkor nincs különbség annak tekintetében, hogy zárt-ajánlatú másodáras módon vagy angol aukció módon játszanak. Mindkét esetben a legnagyobb ajánlatot tevő játékos nyer, ő fizeti be a második legnagyobb ajánlatot, és a többiek nem fizetnek semmit.

Ha a játékban rejlő információ tartalomra is figyelünk, akkor különbségek vannak. Az angol aukció lejátszása közben az aukcióból kiálló játékosok sorra nyilvánítják ki licitjüket, végül csak a nyertes licitjét nem ismerjük meg.

Ha ugyanezt, zárt-ajánlatú másodáras aukcióként értelmezzük, akkor az eredmény kihirdetése után csak a nyertes, tehát a legnagyobb licitet adó személye és a második legnagyobb licit értéke derül ki.

A bevezető jellegû előadás során szükséges egyszerűsítéseket tennünk ahhoz, hogy a legalapvetőbb elveket megérthessük. Ilyen egyszerúsítés, hogy az egész könyvben kizárólag a magán értékelések esetére szorítkozunk. A magán értékelés feltevése mellett a két-két lejátszás okozta információ különbség a mi tárgyalásunk szempontjából nem releváns, emiatt a továbbiakban nem teszünk különbséget az angol aukció, és a zártajánlatú másodáras aukció közt, hasonlóan a holland aukció és a zárt-ajánlatú elsőáras aukció között sem. Ezután egyszerúen elsőáras vagy másodáras aukciókra hivatkozunk.

\subsection{A szimmetrikus modell}

Az aukció nyertese az a játékos, aki az árverés tárgyát kézhez kapja. Egy aukciót standard aukciónak mondunk, ha az aukció konkrét lejátszási szabályai a nyertes játékost, mint a legnagyobb licitet leadó játékost definiálják.

Nem standard aukcióra a legegyszerúbb példa a lottó, vagy valamilyen rezervációs árat használó aukció. Standard aukcióra a legegyszerúbb példák az elsőáras és a másodáras aukciók. E fejezetben először a másodáras aukcióval foglalkozunk, mert mint később látni fogjuk, ez a fajta lejátszás nagyon sok szempontból a legegyszerűbb, a legkézenfekvőbb és a legigazságosabb.

Az eddig tárgyalt aukció lebonyolítások mind olyanok voltak, hogy csak a nyertes számára írnak elő fizetési kötelezettséget. Ez nem feltétlen van mindig így. Például a lottóban minden résztvevő fizet, de még olyan aukció is elképzelhető, hogy egyedül a nyertes nem fizet. Ilyen egzotikus aukciókat is vizsgálunk majd az 5 fejezetben. A modell építésére visszatérve szét kell választanunk tehát a fizetés eseményét és a nyerés eseményét. Amikor e két esemény egybeesik, akkor az aukciót nyertes fizet típusú aukciónak mondjuk. 
Egyetlen terméket szeretnénk árverezni $N$ számú potenciális vevő között. Az $i$-edik licitáló a többiektôl függetlenül ismeri az árverezendő objektum $x_{i}$ értékét. Az $i$-edik licitáló természetesen nem ismeri a $j$-edik játékos $x_{j}$ értékelését, az számára egy $X_{j}$ valószínúségi változó realizációja. Ugyanígy $X_{i}$ az összes többi számára egy valószínúségi változó. Feltesszük, hogy az így kapott

$$
X_{1}, X_{2}, \cdots, X_{N}
$$

valószínűségi változók függetlenek; azonos eloszlásúak; folytonosan differenciálható eloszlásfüggvényük $F$; amelynek a deriváltja a sûrúségfüggvény, tehát $F^{\prime}=f$. A modellt azért nevezzük szimmetrikusnak, mert mindegyik $X_{i}$ értékelés eloszlása ugyanaz.

Minden aukció formában az $i$-edik játékos stratégia- vagy licitfüggvénye

$$
\beta_{i}:[0, \omega] \rightarrow \mathbb{R}
$$

A $\beta_{i}(x)=b$ azt fejezi ki, hogy az $i$-edik játékos az $x$ értékelés esetén $b$ licitet tesz. A játék kifizetési függvénye persze függ a konkrét aukció konkrét formájától. Az egyes játékosok úgy alakítják ki a stratégiájukat, hogy a kifizetési (,,pay off”) függvényük várható értékét maximalizálják. Ez alatt azt értem, hogy a játékos az adott $x$ értékelése mellett olyan $b$ licitet keres, amellyel a

$$
P(\{b \text {-vel nyer }\}) \cdot E(x \mid\{b \text {-vel nyer }\})-P(\{b \text {-vel fizet }\}) \cdot E(C \mid\{b \text {-vel fizet }\})
$$

kifejezést maximalizálja. Minden egyes játékos számára a bevétel az aukció tárgyának megszerzése, ami számára nem valószínúségi változó, hiszen $x$ a tárgy értéke a játékos számára. A $C$ a nyertes fizetési kötelezettsége, amely a konkrét aukció formától függ. Azt kaptuk tehát, hogy a várható profit maximalizálása azt jelenti, hogy rögzített $x$ értékeléshez a játékos olyan $b$ licitet keres, amely a $b \mapsto \Pi(b, x)$ függvényt maximalizálja, ahol

$$
\Pi(b, x)=P(\{b \text {-vel nyer }\}) x-P(\{b \text {-vel fizet }\}) \cdot E(C \mid\{b \text {-vel fizet }\}) .
$$

A fenti formula nem csak a szóban forgó játékos $x$ értékelésétől és $b$ licitjétől függ, hiszen a $C$ valószínúségi változó értéke függ vagy függhet a többi játékos licitjeitől.

Ha az $i$-edik játékos a $\beta_{i}$ licitfüggvényt használja, akkor a $\left(\beta_{1}, \ldots, \beta_{N}\right)$ licit $N$-es Nash-egyensúlyi helyzetet reprezentál, ha minden $i=1, \ldots, N$ mellett és minden $x \in$ $[0, \omega]$ értékelésre

$$
\Pi\left(\beta_{i}(x), x\right) \geq \Pi(b, x)
$$

minden $b$ licit mellett. Feltéve, hogy az összes többi játékos is a $\beta_{j}$ licitfüggvényt használja. A Nash-egyensúlyi $\left(\beta_{1}, \ldots, \beta_{N}\right)$ licitrendszert szimmetrikusnak mondjuk, ha valamennyi licitfüggvény azonos, azaz $\beta=\beta_{i}$ minden $i$ játékosra.

Még a fenti szimmetrikus modellben is előfordulhat nem szimmetrikus Nashegyensúly, amint például azt a 20 oldalon látjuk, egy két szereplős másodáras aukció keretében. Egy lényeges egyszerúsítés, hogy az első szakaszokban első- és másodáras aukció szimmetrikus Nash-egyensúlyát keressük. 
A várható befizetés (,expected payment”) konkrét alakja függ a konkrét aukció konkrét definíciójától. Az intuitív értelmezés az, hogy amennyiben mindenki a $\beta$ licitfüggvénnyel játszik 3 akkor a játékos számára a játék lefolyását csak az értékelése határozza meg. Ha $x$ a játékos értékelése, akkor az aukcióban való részvétel várhatóan $m(x)$ összeg befizetésével jár a játékos részérôl. Kicsit pontosabban

$$
m(x)=P(\{\beta(x) \text {-el fizetés }\}) E(\{\text { befizetés }\} \mid\{\beta(x) \text {-el fizetés }\}) .
$$

Így a játékos maximalizálandó profit függvényére a

$$
\Pi(b, x)=P(\{b \text {-vel nyer }\}) x-m\left(\beta^{-1}(b)\right)
$$

formulát kapjuk.

1.1. lemma. Legyenek $X_{1}, X_{2}, \ldots, X_{n}$ független, azonos eloszlású valószínúségi változók a közös $F$ eloszlásfüggvénnyel. Jelölje $Y_{1}^{(N-1)}=\max _{j>1} X_{j}$, ezek közül $N-1$ darab maximumát jelölő valószínüségi változót. Legyen $G$ az $Y_{1}^{(N-1)}$ valószínüségi változó eloszlásfüggvénye, míg g a sürüségfüggvénye. Ekkor

$$
G=F^{N-1}, \quad \text { és } \quad g=(N-1) F^{N-2} f .
$$

Bizonyítás. Világos, hogy $Y_{1}^{(N-1)}<r$ akkor és csak akkor, ha $X_{i}<r$ minden szóba jövő $i=2, \ldots, N$ mellett. Így a függetlenség szerint $G(r)=P\left(Y_{1}^{(N-1)}<r\right)=P\left(X_{2}<\right.$ $r) \cdot, \ldots, P\left(X_{n}<r\right)=F^{N-1}(r)$.

1.2. lemma. Legyen g a fenti $Y_{1}^{(N-1)}$ valószínüségi változó sürüségfüggvénye. Jelölje $Y_{2}^{(N)}=\max 2_{i=1, \ldots, N} X_{i}$ ezen $N$ valószínüségi változó második maximumát jelölô valószínüségi változót. Ennek $F_{2}$ sürüség-és $f_{2}$ eloszlásfüggvényére:

$$
F_{2}=N F^{N-1}-(N-1) F^{N} \quad \text { és } f_{2}=N(1-F) g .
$$

Bizonyítás. Először írjuk fel $Y_{2}^{(N)}$ eloszlásfüggvényét. Látható, hogy az $\left(Y_{2} \leq x\right)$ esemény vagy úgy teljesül, hogy minden $\left(X_{i} \leq x\right)$ fennáll, vagy úgy teljesül, hogy $n-1$ darab $i$ mellett $\left(X_{i} \leq x\right)$ teljesül, és egyetlen darab $i$-re nem teljesül. Ez utóbbi $N$ különbözőképpen lehetséges, ezért

$$
\begin{aligned}
F_{2}(x)=F(x)^{N}+N F(x)^{N-1}(1-F(x))=F(x)^{N}+ & N F(x)^{N-1}-N F(x)^{N}= \\
& N F(x)^{N-1}-(N-1) F(x)^{N} .
\end{aligned}
$$

Ennek deriváltja persze a sûrúségfüggvény, tehát

$$
\begin{aligned}
f_{2}(x)=N(N-1) F(x)^{N-2} f(x)-(N-1) N F(x)^{N-1} f(x) & = \\
N(1-F(x))(N-1) F(x)^{N-2} f(x) & =N(1-F(x)) g(x) .
\end{aligned}
$$

Ezt kellett belátni.

\footnotetext{
${ }^{3}$ Például azért, mert a játékosok elôtt ismert a szimmetrikus Nash-egyensúly.
} 
A bevezetett $G$ függvény jelentősége abban áll, hogy a $G(x)$ annak a valószínúsége, hogy az $N-1$ értékelés mindegyike $x$ értékelés alatt marad.

1.3. állítás. Tegyük fel, hogy a szimmetrikus modellben lejátszott standard aukciónál a $\beta$ szigorúan monoton növó licitfüggvénnyel játszanak a játékosok. Ha az 1 játékos b licitet ad le az $x_{1}$ értékelése mellett, míg a többiek a $\beta$ licitfüggvénnyel adják a licitjeiket, akkor $G\left(\beta^{-1}(b)\right)$ az 1 játékos nyerésének valószínüsége.

Ennek következményeképpen a játékos várható profit függvénye:

$$
\Pi(b, x)=G\left(\beta^{-1}(b)\right) x-m\left(\beta^{-1}(b)\right)
$$

Ha tehát, ha 1 játékos is $x$ értékeléséhez $\beta(x)$ licitet társít, akkor az x értékeléssel való nyerés valószínüsége $G(x)$.

Egy nyertes fizet típusú aukcióban ezért a várható befizetési függvény:

$$
m(x)=G(x) E\left(C \mid Y_{1}^{(N-1)}<x\right)
$$

alakú, ahol C a konkrét aukcióban a nyeréssel együtt járó befizetési kötelezettség.

Bizonyítás. A $\beta$ függvény a legnagyobb helyen veszi fel legnagyobb értékét, ergo a

$$
\max \left\{\beta\left(X_{2}\right), \beta\left(X_{3}\right), \ldots, \beta\left(X_{N}\right)\right\}=\beta\left(Y_{1}^{(N-1)}\right)
$$

valószínúségi változók azonosak. Így $b$ pontosan akkor a legnagyobb licit, ha

$$
\left(\beta\left(Y_{1}^{(N-1)}\right)<b\right)=\left(Y_{1}^{(N-1)}<\beta^{-1}(b)\right)
$$

esemény fennáll. Ez az esemény éppen a $b$ licittel való nyerés eseménye, hiszen standard aukcióban nyerni annyit tesz, mint a legnagyobb licitet adni. Ennek valószínúsége éppen $G\left(\beta^{-1}(b)\right)$.

Speciálisan a $b=\beta\left(x_{1}\right)$ esetben $G\left(x_{1}\right)$.

Nash-egyensúlyi helyzetben egyetlen játékos várható profitja sem nô az egyensúlyi licittől való eltéréssel. Formálisan minden $b$ licit mellett

$$
\Pi(\beta(x), x) \geq \Pi(b, x),
$$

ahol $\Pi(b, x)$ jelöli az $i$-edik játékos profitjának várható értékét. Világos, hogy standard, nyertes fizet szerkesztésú aukcióban ez a függvény

$$
\Pi(b, x)=G\left(\beta^{-1}(b)\right) x-G\left(\beta^{-1}(b)\right) \cdot E\left(C \mid Y_{1}^{(N-1)}<\beta^{-1}(b)\right)
$$

feltéve, hogy a többi játékos is a $\beta$ licitfüggvényt használja. 


\subsection{Másodáras aukció}

Írjuk fel az $i$-edik játékos kifizetési függvényét. Persze a profit nem más, mint a bevétel és a költség különbsége. Ha a játékos nem nyeri az aukciót, akkor sem bevétele sem költsége nincs. Ha a játékos nyeri az aukciót, akkor a bevétele a tárgynak a számára definiált $x_{i}$ értékelése és a kiadása az ezért az objektumért befizetett összeg. Tehát, ha $b_{i}$ jelöli az $i$-edik játékos licitjét, akkor másodáras aukció esetén a kifizetési függvény a következő:

$$
\Pi_{i}= \begin{cases}x_{i}-\max _{j \neq i} b_{j} & , \text { ha } b_{i}>\max _{i \neq j} b_{j}, \\ 0 & , \text { egyébként. }\end{cases}
$$

Ez azt jelenti, hogy a másodáras aukció egy olyan standard aukció, amit a $C=$ $\beta\left(Y_{1}^{(N-1)}\right)$ befizetés definiál. Ennek megfelelóen, a $\Pi$ speciális eseteként, a másodáras aukcióban szereplő játékosok Nash-egyensúlyban a

$$
\Pi(b, x)=G\left(\beta^{-1}(b)\right) x-G\left(\beta^{-1}(b)\right) E\left(\beta\left(Y_{1}^{(N-1)}\right) \mid Y_{1}^{(N-1)}<\beta^{-1}(b)\right)
$$

függvényt maximalizálják.

1.4. állítás. A másodáras aukciónak a $\beta=\mathrm{id}$ függvény Nash-egyensúlyi licitfüggvénye.

Bizonyítás. Azt kell ellenőriznünk, hogy a $\Pi(\beta(x), x) \geq \Pi(b, x)$ egyenlőség minden $x$ értékelés és $b$ licit mellett fennáll. Ebben a speciális esetben ez a

$$
G(x) x-G(x) E\left(Y_{1}^{(N-1)} \mid Y_{1}^{(N-1)}<x\right) \geq G(b) x-G(b) E\left(Y_{1}^{(N-1)} \mid Y_{1}^{(N-1)}<b\right)
$$

egyenlőtlenséggel ekvivalens. Mivel $g$ az $Y_{1}^{(N-1)}$ valószínúségi változó sûrűségfüggvénye, és a feltételes várható értéket az

$$
E\left(Y_{1}^{(N-1)} \mid Y_{1}^{(N-1)}<x\right)=\frac{1}{G(x)} \int_{0}^{x} t g(t) d t
$$

formula adja, ezért átrendezés után a fenti egyenlőtlenség ekvivalens alakja

$$
x(G(x)-G(b)) \geq \int_{b}^{x} \operatorname{tg}(t) d t,
$$

ami az integrálás triviális becsléséből $t$-re, majd a Newton-Leibnitz-tételből adódik tetszőleges $b$ licit és $x$ értékelés mellett.

Azt kaptuk tehát, hogy az igazmondás egy Nash-egyensúlyi stratégia. A jegyzetben a továbbiakban is a Nash-egyensúlyi koncepciót használjuk, és amikor egyensúlyról van szó, az alatt mindig azt értjük.

A fenti játék egy kis módosításával látjuk, hogy az identitás nem az egyedüli Nashegyensúly. Tegyük fel, hogy $\omega$ egy véges szám, $N=2$, és a játék definícióját annyiban 
módosítjuk, hogy foglalkozunk az egyenlo licitek esetével is: Ha a legmagasabb licitet egyszerre adja a két játékos, akkor valamilyen $p$ valószínúséggel nyeri az egyik és $1-p$ valószínűséggel a másik. A nyertes viszi a kikiáltás tárgyát és fizeti a vesztes licitjét, ergo a közös licitet. Látható, hogy a $\left(\beta_{1}, \beta_{2}\right)$ pár Nash-egyensúlyi stratégia, amennyiben $\beta_{1}(x)=\omega, \beta_{2}(x)=0$ minden $x$ értékelés mellett.

Valóban 1 játékos mindig nyer, és mindig 0-t fizet, ergo várható profitja az $x$ értékelése.

Világos, hogy az ettől eltérő licittel ez a profit nem változik, míg a 2 játékos zérus licitet ad le. Kivétel, mikor 1 is zérust licitál, de ekkor 1 nyerhet $p$ valószínúséggel, tehát várható profitja $p x \leq x$. A 2 játékos veszt és várható profitja zérus. Amíg 1 játékos a maximális licitet adja, addig a 0 licittől való eltérés ugyanígy 0 várható profitot eredményez egyetlen kivétellel, amikor a 2 játékos licitje is $\omega$, ekkor viszont $(1-p)(x-\omega) \leq 0$ a várható profit. Mindkét játékosra meggondoltuk, hogy a várható profitja nem növelhetô a $\beta_{1}$ illetve $\beta_{2}$ licitfüggvényektől való eltéréssel. A $\left(\beta_{1}, \beta_{2}\right)$ pár Nash-egyensúlyt definiál.

Érdemes viszont látni, hogy a másodáras aukció olyan speciális, hogy nem csak Nash-egyensúlyi stratégia az igazmondás, de még domináns egyensúlyi stratégia is. Ez azt jelenti, hogy bármelyik játékos a többitôl függetlenül, ha az identikus licitfüggvénytôl eltér, akkor a várható profitja nem nagyobb, mintha ennek a stratégiának a használata mellett maradt volna, bármit is tesznek a többiek.

1.5. állítás. Magán értékelésú másodáras aukció esetén a $\beta=$ id függvény egy domináns egyensúlyi stratégia.

Bizonyitás. A jelöléseket egyszerúsítve tegyük fel, hogy az 1 játékos stratégiájáról van szó. Tegyük fel - indirekt - , hogy van olyan $x_{1}$, hogy $z_{1}=\beta_{1}\left(x_{1}\right) \neq x_{1}$. Jelölje $p_{1}=$ $\max _{j>1} b_{j}$. Nézzük először, ha $z_{1}<x_{1}$. Persze ezen belül három eset van:

1. $p_{1} \leq z_{1}<x_{1}$. Ekkor játékosunk nyer, és profitja $x_{1}-p_{1}$, ugyanúgy, mintha $x_{1}=$ $z_{1}$ lett volna.

2. $z_{1}<x_{1}<p_{1}$. Ekkor játékosunk veszít, profitja 0 , ugyanúgy, mintha $x_{1}=z_{1}$ lett volna.

3. $z_{1}<p_{1} \leq x_{1}$. Ekkor játékosunk veszít, profitja tehát 0 , de ha $z_{1}=x_{1}$ lett volna, akkor nyert volna a pozitív $x_{1}-p_{1}$ profit mellett. Ez azt jelenti, hogy ebben az esetben játékosunk rosszabbul járt a $z_{1}<x_{1}$ licittel.

Most nézzük az $x_{1}<z_{1}$ esetet:

1. $x_{1}<z_{1} \leq p_{1}$. Ekkor játékosunk veszít, profitja 0 , ugyanúgy, mintha $x_{1}=z_{1}$ lett volna.

2. $p_{1} \leq x_{1}<z_{1}$. Ekkor játékosunk nyer, és profitja $x_{1}-p_{1}$, ugyanúgy, mintha $x_{1}=$ $z_{1}$ lett volna.

3. $x_{1}<p_{1}<z_{1}$. Ekkor játékosunk nyer, de a negatív $x_{1}-p_{1}$ profittal, míg ha $z_{1}=x_{1}$ lett volna, akkor vesztesként 0 profittal jobban járt volna. 
Összességében azt találtuk, hogy bizonyos esetekben ugyanazt a profitot realizálná a játékos, mint az igazmondással, de bizonyos esetekben rosszabbul jár. Ezt kellett belátni.

Vegyük észre, hogy a fenti állítás igaz marad akkor is, ha

a) az egyes játékosok értékelései más-más eloszlás szerint alakulnak, azaz a nem szimmetrikus esetben is, vagy ha

b) a játékosok nem semlegesek a kockázatokkal szemben, azaz a (II) definícióban $\Pi$ helyett a játékos feladata az $u \circ \Pi$ függvény maximalizálása, ahol $u(0)=0$ és $u$ szigorúan monoton növő.

1.6. állítás (várható befizetés (,„expected payment”), a kikiáltó várható bevétele). Egyéni értékelésü, szimmetrikus, másodáras aukció esetén az egyes játékosok várható befizetései az x értékelés mellett:

$$
m(x)=G(x) E\left(Y_{1}^{(N-1)} \mid Y_{1}^{(N-1)}<x\right)=\int_{0}^{x} y g(y) d y .
$$

A kikiáltó várható bevétele pedig

$$
E\left(Y_{2}^{(N)}\right)=N \int_{0}^{\omega} y(1-F(y)) g(y) d y .
$$

Bizonyítás. Legyen $x_{1}$ mondjuk az $i=1$ játékos értékelése. Az ő várható befizetése az $x_{1}$ értékeléshez rendelt $\beta\left(x_{1}\right)$ licit melletti nyerés valószínúségének és az ebben az esetben várható második legnagyobb licit értékének szorzata. A játékosok racionálisak, és minden játékos a $\beta=$ id stratégia mellett licitál, amint ezt láttuk az 1.5 állításban. Eszerint a legnagyobb értékelésú játékos nyeri az aukciót, és az 1 játékos pontosan akkor nyer, ha az $Y_{1}^{(N-1)}<x_{1}$ esemény fennáll. Így a nyerés valószínúsége éppen $G\left(x_{1}\right)$. Hasonlóan az összes játékos licitfüggvénye az identitás függvény, ezért a nyerés feltétele melletti várható befizetés $E\left(Y_{1}^{(N-1)} \mid Y_{1}^{(N-1)}<x_{1}\right)$. Magyarul

$$
m(x)=G(x) E\left(Y_{1}^{N-1} \mid Y_{1}^{(N-1)}<x\right) .
$$

Viszont $Y_{1}^{(N-1)}$ tartója $[0, \omega]$ intervallum és sûrûségfüggvénye $g$, így

$$
E\left(Y_{1}^{(N-1)} \mid Y_{1}^{(N-1)}<x_{1}\right)=\frac{1}{P\left(Y_{1}^{(N-1)}<x_{1}\right)} \int_{0}^{x_{1}} y g(y) d y=\frac{1}{G\left(x_{1}\right)} \int_{0}^{x_{1}} y g(y) d y .
$$

Hasonlóan, a kikiáltó várható bevétele az $N$ darab licit második legnagyobbika, de a licitek megegyeznek az értékelésekkel, ergo a második legnagyobb értékelés várható értékével. $\mathrm{Az} Y_{2}^{(N)}$ valószínúségi változó ismert eloszlása szerint

$$
E\left(Y_{2}^{(N)}\right)=\int_{0}^{\omega} y N(1-F(y)) g(y) d y .
$$

Ezt kellett belátni. 
Fontos megértenünk a várható befizetés függvény és az ex post várható befizetés közti különbséget. Ha a játékos $x$ értékelése ismert, akkor $m(x)$ jelöli ezen értékelés melletti várható befizetését, vagy néha: ex ant ${ }^{4}$ várható befizetését. Az $x$ konkrét értékét persze a játékoson kívül senki nem ismeri. Például a kikiáltó sem. Ha egy másik játékos, vagy a kikiáltó, vagy egy harmadik személy oldaláról figyeljük az eseményeket, akkor az

$$
m \circ X
$$

az $X$ értékelést kifejezô valószínúségi változó egy transzformáltja, amelynek konkrét realizációját csak az aukció lejátszása után ismerhetnénk meg. Ennek $E(m(X))$ várható értékét tekintjük úgy, mint a játékos ex pos5 várható befizetését. A kikiáltó szemszögébe helyezkedve az aukció várható bevétele nem más, mint ezen játékosonkénti ex ante várható befizetések összege. Ez a gondolat független az aukció megszervezési módjától, nyilván valamennyi aukcióra igaz, hiszen a kikiáltó bevétele az aukcióban résztvevő felektől és csak azoktól származik.

Az alábbi nagyon fontos megjegyzésre később is visszatérünk. Megmutatjuk, hogy a kikiáltó várható hasznára vonatkozó formula az $Y_{2}^{(N)}$ valószínúségi változó sûrúségfüggvényének konkrét ismerete nélkül is adódik, pusztán a várható befizetés függvény konkrét alakjából.

1.7. megjegyzés (ex post várható befizetés). Ha a várható befizetés függvény

$$
m(x)=\int_{0}^{x} y g(y) d y
$$

alakú, akkor az ex post várható befizetés értéke

$$
E(m(X))=\int_{0}^{\omega} y(1-F(y)) g(y) d y .
$$

Ez minden résztvevơre fennáll, és a résztvevők várható befizetéseinek összege a kikiáltó várható bevétele, így a kikiáltó várható bevételére vonatkozó képletet újra igazoltuk.

Bizonyítás. Számoljuk most ki az $E(m(X))$ várható értéket. A számolás trükkje a Fubini-tétel, és az a tény, hogy minden $x, y \in[0, \omega]$ mellett $\chi_{[0, x]}(y)=\chi_{[y, \omega]}(x)$. Ekkor:

$$
\begin{gathered}
E(m(X))=\int_{0}^{\omega} m(x) f(x) d x=\int_{0}^{\omega}\left(\int_{0}^{x} y g(y) d y\right) f(x) d x= \\
\int_{0}^{\omega} \int_{0}^{\omega} \chi_{[0, x]}(y) y g(y) f(x) d y d x=\int_{0}^{\omega} \int_{0}^{\omega} \chi_{[y, \omega]}(x) y g(y) f(x) d x d y= \\
\int_{0}^{\omega}\left(\int_{y}^{\omega} f(x) d x\right) y g(y) d y=\int_{0}^{\omega}(1-F(y)) y g(y) d y .
\end{gathered}
$$

Persze ez utóbbi érték $N$-szerese a kikiáltó várható bevétele.

\footnotetext{
${ }^{4}$ Értsd az esemény, azaz az aukció lejátszása előtti.

${ }^{5}$ Értsd az esemény, azaz az aukció lejátszása utáni.
} 

A MÁSODÁRAS AUKCIÓK esetén bevezetett jelölések megtartásával az i-edik játékos profitja definiálja az elsőáras aukciót:

$$
\Pi_{i}= \begin{cases}x_{i}-b_{i} & , \text { ha } b_{i}>\max _{i \neq j} b_{j} \\ 0 & , \text { egyébként. }\end{cases}
$$

A definíció szerint tehát a legnagyobb licitet ajánló játékos nyer, és az általa felajánlott licitet kell fizetnie. Ez azt jelenti, hogy az elsőáras aukció egy olyan standard aukció, ahol a befizetési valószínúségi változóra $C=b$ konstans, ahol $b$ a nyertes licit. A profit függvényt definiáló $(\Pi)$ azonosság speciális esete tehát

$$
\begin{aligned}
& \Pi(b, x)=G\left(\beta^{-1}(b)\right) x-G\left(\beta^{-1}(b)\right) \cdot E\left(b \mid \beta\left(Y_{1}^{(N-1)}\right)<b\right) \\
& G\left(\beta^{-1}(b)\right)(x-b) .
\end{aligned}
$$

Egy apró megjegyzést rögtön érdemes tenni. Az első, hogy $\beta(x)=x$ stratégia minden játékos számára nulla profitot hoz, ezért így ez nem lehet Nash-egyensúlyi stratégia. Ugyanis abban az esetben, amikor $p_{1}<b_{1}<x_{1}$ áll fenn, $\left(p_{1}=\max _{j>1} b_{j}\right)$, az $i=1$ játékos nyer és $x_{1}-b_{1}>0$ profittal lép ki az aukcióból, míg ha $b_{1}=x_{1}$ lenne, akkor profitja zérus lenne. Érdekében áll tehát a játékosnak lefelé eltérni az értékeléstől. Nyilvánvaló, hogy a felfelé eltérés esetleg negatív hasznot eredményez, aminél a $b_{i}=x_{i}$ már jobb is, így $\beta(x)>x$ egyensúlyi stratégia nem lehetséges, tehát $\beta(x) \leq x$. Speciálisan $\beta(0)=0$.

Ha $b>\beta(\omega)$ lenne, akkor 1 játékos a licitje csökkentésével a profitját növelhetné. Emiatt Nash-egyensúlyi helyzetben $b \in[0, \beta(\omega)]$.

Tegyük fel, hogy az elsőáras aukciónak van $\beta:[0, \omega] \rightarrow \mathbb{R}$ szimmetrikus egyensúlyi licitfüggvénye, amely szigorúan monoton növő és $\beta(0)=0$. Legyen az $i=1$ játékos licitje $b$, és a többi játékos a $\beta$ stratégiát játssza. Az egyensúly definíciója szerint

$$
\Pi(\beta(x), x) \geq \Pi(b, x)
$$

minden $x$ értékelés és minden $b \in[0, \beta(\omega)]$ licit mellett. Jelölje most $z=\beta^{-1}(b)$ értékelést. Világos, hogy $z \in[0, \omega]$, és

$$
\Pi(b, x)=G\left(\beta^{-1}(b)\right)(x-b)=G(z)(x-\beta(z)) .
$$

Speciálisan a $b=\beta(x)$ eset a fenti sorban $z=x$-t jelent, ergo

$$
\Pi(\beta(x), x)=G(x)(x-\beta(x)) .
$$

Azt kaptuk tehát, hogy a Nash-egyensúly [2.2 feltétele avval ekvivalens, hogy minden rögzített $x$ mellett a

$$
z \mapsto G(z)(x-\beta(z))
$$


függvény a $z=x$ helyen veszi fel a legnagyobb értékét. A Fermat-elv szerint a fenti függvény deriváltja ezért a $z=x$ helyen zérus:

$$
g(x)(x-\beta(x))-G(x) \beta^{\prime}(x)=0 .
$$

Szorzás és átrendezés után ez azt jelenti, hogy

$$
g(x) x=\beta^{\prime}(x) G(x)+g(x) \beta(x)=(\beta(x) G(x))^{\prime} .
$$

Newton-Leibniz-tétel és $\beta(0)=0$ szerint

$$
\beta(x) G(x)=\beta(x) G(x)-\beta(0) G(0)=\int_{0}^{x} \operatorname{tg}(t) d t,
$$

amiből a korábban már szereplő

$$
\beta(x)=\frac{1}{G(x)} \int_{0}^{x} \operatorname{tg}(t) d t=E\left(Y_{1}^{(N-1)} \mid Y_{1}^{(N-1)}<x\right)
$$

formula adódik.

Vizsgáljuk most meg ezt a függvényt. Világos, hogy az értelmezési tartomány olyan $x \in[0, \omega]$ pontokat tartalmaz, amelyekre $G(x)>0$. A továbbiakban az egyszerúség kedvéért feltesszük, hogy minden $x>0$ pontban $G(x)>0$, így $\beta:[0, \omega] \rightarrow \mathbb{R}$.

2.1. lemma. Legyen $\beta:[0, \omega] \rightarrow \mathbb{R}, \beta(x)=E\left(Y_{1}^{(N-1)} \mid Y_{1}^{(N-1)}<x\right)$ definícióval megadott függvény.

1. Ekkor

$$
\beta(x)=\frac{1}{G(x)} \int_{0}^{x} \operatorname{tg}(t) d t=x-\frac{1}{G(x)} \int_{0}^{x} G(y) d y
$$

emiatt $\beta(x)<x$ fennáll minden $x>0$ mellett ${ }^{1}$

2. A $\beta$ függvény az egyetlen megoldása a

$$
\beta^{\prime}(x)=\frac{g(x)}{G(x)}(x-\beta(x))
$$

differenciálegyenletnek a $(0, \omega)$ intervallumon, így $\beta$ szigorúan monoton nö.

3. Minden $x \in[0, \omega]$ mellett

$$
\beta(x) \leq E\left(Y_{1}^{N-1}\right) .
$$

\footnotetext{
${ }^{1}$ Emiatt persze $\lim _{x \rightarrow 0+} \beta(x)=0$.
} 
Bizonyitás. Az elsô egyenlőség nyilvánvaló. Parciális integrálással:

$$
\frac{1}{G(x)} \int_{0}^{x} y g(y) d y=\frac{1}{G(x)}\left([y G(y)]_{0}^{x}-\int_{0}^{x} G(y) d y\right)=x-\frac{1}{G(x)} \int_{0}^{x} G(y) d y .
$$

A deriváltat számolva:

$$
\begin{aligned}
& \beta^{\prime}(x)=\frac{-g(x)}{G^{2}(x)} \int_{0}^{x} \operatorname{tg}(t) d t+\frac{x g(x)}{G(x)}=\frac{g(x)}{G(x)}\left(x-\frac{1}{G(x)} \int_{0}^{x} \operatorname{tg}(t) d t\right)= \\
& \frac{g(x)}{G(x)}(x-\beta(x)) .
\end{aligned}
$$

A monotonitás szerint minden $x \in[0, \omega]$

$$
\beta(x)=E\left(Y_{1}^{(N-1)} \mid Y_{1}^{(N-1)}<x\right) \leq E\left(Y_{1}^{(N-1)} \mid Y_{1}^{(N-1)}<\omega\right)=E\left(Y_{1}^{(N-1)}\right) .
$$

Ezeket kellett belátni.

A fentiekben azt mutattuk meg, hogy ha az elsőáras, szimmetrikus, magán értékelésú aukciónak van Nash-egyensúlyi licitfüggvénye, akkor az csak a fenti $\beta$ lehet.

2.2. állítás. Szimmetrikus, magán értékelésü, elsôáras aukció Nash-egyensúlyi licitfüggvénye a

$$
\beta(x)=E\left(Y_{1}^{(N-1)} \mid Y_{1}^{(N-1)}<x\right)
$$

függvény.

Bizonyítás. Tegyük fel, hogy hogy a $j>1$ játékosok a $\beta$ függvénnyel licitálnak. Írjuk fel az 1 játékos várható profitját. Ha az 1 játékos az $x$ értékeléséhez a $b$ licitet rendeli, akkor a várható profitja $z=\beta^{-1}(b)$ jelölés mellett

$$
\begin{aligned}
& \Pi(b, x)=G\left(\beta^{-1}(b)\right)(x-b)= \\
& \quad G(z)(x-\beta(z))=G(z) x-G(z)\left(z-\frac{1}{G(z)} \int_{0}^{z} G(y) d y\right)= \\
& G(z)(x-z)+\int_{0}^{z} G(y) d y .
\end{aligned}
$$

Speciálisan, ha $b=\beta(x)$, azaz $z=x$, akkor $\Pi(\beta(x), x)=\int_{0}^{x} G(y) d y$. Így

$$
\begin{array}{r}
\Pi(\beta(x), x)-\Pi(b, x)=\int_{0}^{x} G(y) d y+G(z)(z-x)-\int_{0}^{z} G(y) d y= \\
G(z)(z-x)-\int_{x}^{z} G(y) d y \geq 0
\end{array}
$$

az integrál triviális becslése szerint, hiszen $G$ egy monoton növekedő függvény. 
Azt mutattuk meg tehát, hogy amennyiben a $j>1$ játékosok mind a $\beta$ függvénnyel licitálnak, akkor az 1 játékos $b \neq \beta(x)$ licitje az ő várható profitját $b=\beta(x)$-hez képest nem növeli. Ezt kellett belátni.

Innen már könnyen származtatható a játékosok várható befizetés függvénye.

2.3. állítás. Szimmetrikus, magán értékelésü, elsóáras aukció egyes játékosainak ex ante várható befizetés függvénye

$$
m(x)=G(x) E\left(Y_{1}^{(N-1)} \mid Y_{1}^{(N-1)}<x\right),
$$

így az ex post várható befizetés értéke játékosonként

$$
E(m(X))=\int_{0}^{\omega} y(1-F(y)) g(y) d y .
$$

A kikiáltó várható bevétele tehát

$$
E\left(\beta\left(Y_{1}^{(N)}\right)\right)=N \cdot E(m(X))=N \int_{0}^{\omega} y(1-F(y)) g(y) d y=E\left(Y_{2}^{(N)}\right) .
$$

Bizonyítás. Világos, hogy $x$ értékeléshez a $\beta(x)$ licit tartozik, és az evvel a licittel való nyerés valószínúsége

$$
G\left(\beta^{-1}(\beta(x))\right)=G(x) .
$$

Így $m(x)=G(x) \beta(x)=G(x) E\left(Y_{1}^{(N-1)} \mid Y_{1}^{(N-1)}<x\right)$. Az 1.7 megjegyzésben láttuk, hogy ha $m$ a fent bizonyított alakú, akkor a várható befizetés értéke éppen a tételben felírt formula. A kikiáltó várható bevétele a játékosok várható befizetéseinek összege, ami az 1.2 lemma szerint éppen $E\left(Y_{2}^{(N)}\right)$.

Példaként számoljuk ki a fent kapott eredményeket, mikor $N=2$ és $F=$ id, azaz minden licitáló értékelése egyenletes eloszlású valószínúségi változó a $[0,1]$ intervallum felett. A másodáras optimális licitfüggvény a 2.1 lemma alapján

$$
\beta(x)=x-\frac{1}{G(x)} \int_{0}^{x} \operatorname{tg}(t) d t=x-\frac{1}{x} \int_{0}^{x} t d t=x-\frac{1}{x} \frac{x^{2}}{2}=\frac{1}{2} x .
$$

Az elsőáras optimális licitfüggvény természetesen az identitás függvény. Mind első-, mind másodáras esetben az egyes játékosok várható befizetés függvénye

$$
m(x)=\int_{0}^{x} \operatorname{tg}(t) d t=\int_{0}^{x} t d t=\frac{x^{2}}{2} .
$$

Az ex post várható befizetés értéke pedig

$$
E(m(X))=\int_{0}^{1} \frac{t^{2}}{2} \cdot 1 d t=\frac{1}{2} \frac{1}{3}=\frac{1}{6},
$$


a kikiáltó várható bevételére tehát

$$
E\left(\beta\left(Y_{1}^{N}\right)\right)=2 E(m(X))=\frac{1}{3} .
$$

Az $Y_{1}^{(2)} / 2$ valószínúségi változóra úgy is tekinthetünk mint az elsőáras aukció kikiáltójának bevételére. Írjuk fel ennek a valószínúségi változónak az eloszlás függvényét.

$$
L^{1}(x)=P\left(Y_{1}^{(2)} / 2<x\right)=P\left(Y_{1}^{(2)}<2 x\right)=F^{2}(2 x)=(2 x)^{2}=4 x^{2} .
$$

Most nézzük a másodáras aukció esetét. Ekkor a kikiáltó bevételét az $Y_{2}^{(2)}$ valószínúségi változó értékei jelentik, hiszen az identitás a Nash-egyensúlyi licitfüggvény. Ha $L^{(2)}$ jelöli a kikiáltó bevételének eloszlását, akkor

$$
L^{(2)}(x)=F^{2}(x)+2 F(x)(1-F(x))=x^{2}+2 x(1-x)=2 x-x^{2}=x(2-x) .
$$

Látható tehát, hogy szó nincs arról, hogy a két aukciónál a kikiáltó várható árbevétele mindig azonos lenne, csupán a várható értékük azonos. Az eloszlás függvényekbool látszik, hogy a kikiáltó számára az elsőáras aukció választása a kockázatok elutasítását jelenti. Kockázatsemleges esetben a kikiáltó az elsô- és másodáras aukció választásával szemben ambivalens, míg kockázatkedvelő kikiáltó inkább a másodáras aukciót preferálja.

Azt, hogy az elsô és másodáras aukcióknak különböző kimenetelei is lehetnek, ennél egyszerübben is láthatjuk. Tegyük fel, hogy az értékelésekre $x_{1}>x_{2}$. Mivel másodáras esetben a $\beta(x)=x$ a licitfüggvény és elsőáras esetben a $\beta(x)=\frac{1}{2} x$ függvénnyel licitálnak a játékosok, látható, hogy $R^{1}=\frac{1}{2} x_{1}$ és $R^{2}=x_{2}$. Viszont $x_{1}>x_{2}$ mellett $x_{1}>\frac{1}{2} x_{1}>x_{2}$ és $x_{1}>x_{2}>\frac{1}{2} x_{1}$ egyaránt előfordulhat, ergo $R^{1}>R^{2}$ és $R^{2}>R^{1}$ is egyaránt lehetséges. 

ELSŐ- ÉS MÁSODÁRAS AUKCIÓ
REZERVÁCIÓS ÁRRAL 

AZ ÁRVERÉS MEGKEZDÉSE előtt a kikiáltó meghatároz egy árat, amelynél kevesebbért nem adja a terméket. Ha az aukció nem éri el ezt a rezervációs árat, akkor eredménytelenül végzódik, tehát a terméket senki nem kapja meg.

A vizsgálatainkban feltesszük, hogy az aukció résztvevői számára a rezervációs ár értéke köztudott tudás, tehát minden résztvevő ismeri a rezervációs árat és ezt a tényt egymásról is mindannyian tudják. Ennek két következménye is van a kialakítandó stratégiájukra nézve valamely standard aukció esetén. Egyrészt, $\beta(x)<r$ csak vesztést eredményezhet, tehát a $\beta(x)=0$ licittel ekvivalens. Másrészt, az $x \geq r$ esetben $\beta(x)<r$ szintén veszteséget jelent, ami optimális nem lehet. Így az optimális licitfüggvényre

$$
r \leq \beta(x), \quad \text { ha } x \geq r \text {. }
$$

Sokszor lesz szükségünk az alábbi várható értékre.

3.1. lemma. A fenti jelöléseket megtartva tetszóleges $x \geq r \geq 0$ mellett,

$$
E\left(Y_{1}^{(N-1)} \vee r \mid Y_{1}^{(N-1)}<x\right)=\frac{r G(r)}{G(x)}+\frac{1}{G(x)} \int_{r}^{x} \operatorname{tg}(t) d t .
$$

Bizonyítás. Jelölje $B=\Omega\left(Y_{1}^{(N-1)}<x\right)$ eseményt és $\mu$ a valószínúségi mértéket. A $B$ mint feltétel melletti valószínúségi mérték $\mu_{B}(A)=\frac{\mu(A \cap B)}{\mu(B)}=\frac{1}{\mu(B)} \int_{A} \chi_{B} d \mu$, ergo $d \mu_{B}=\frac{1}{\mu(B)} \chi_{B} d \mu$. Így a $\mu$ mérték helyettesítésével

$$
\begin{gathered}
E\left(Y_{1}^{(N-1)} \vee r \mid Y_{1}^{(N-1)}<x\right)=\int_{\Omega} Y_{1}^{(N-1)} \vee r d \mu_{B}=\int_{\Omega}\left(Y_{1}^{(N-1)} \vee r\right) \frac{1}{\mu(B)} \chi_{B} d \mu= \\
\frac{1}{G(x)} \int_{\Omega\left(Y_{1}<x\right)} Y_{1} \vee r d \mu=\frac{1}{G(x)}\left(\int_{\Omega\left(Y_{1}<r\right)} Y_{1} \vee r d \mu+\int_{\Omega\left(r \leq Y_{1}<x\right)} Y_{1} \vee r d \mu\right)= \\
\frac{1}{G(x)}\left(\int_{\Omega\left(Y_{1}<r\right)} r d \mu+\int_{\Omega\left(r \leq Y_{1}<x\right)} Y_{1} d \mu\right)=\frac{1}{G(x)}\left(r G(r)+\int_{r}^{x} t g(t) d t .\right)
\end{gathered}
$$

Ezt kellett belátni.

A 2.1 lemmának megfelelően vizsgáljuk meg a fent definiált $\beta:[0, \omega] \rightarrow \mathbb{R}$ függvényt.

3.2. lemma. Legyen $\beta:[0, \omega] \rightarrow \mathbb{R}$,

$$
\beta(x)= \begin{cases}E\left(Y_{1}^{(N-1)} \vee r \mid Y_{1}^{(N-1)}<x\right), & \text { ha } x \geq r \\ 0, & \text { ha } x<r\end{cases}
$$

definícióval megadott függvény. 
1. Ekkor minden $x \geq r$ mellett

$$
\beta(x)=\frac{1}{G(x)}\left(r G(r)+\int_{r}^{x} \operatorname{tg}(t) d t\right)=x-\frac{1}{G(x)} \int_{r}^{x} G(y) d y,
$$

emiatt $\beta(x)<x$ fennáll minden $x>r$ mellett és $\beta(r)=r$.

2. A $\beta$ függvény az egyetlen megoldása a

$$
\beta^{\prime}(x)=\frac{g(x)}{G(x)}(x-\beta(x)), \beta(r)=r
$$

kezdetiérték-feladatnak az $[r, \omega]$ intervallum felett, így $\beta$ szigorúan monoton nó.

3. Minden $x \in[r, \omega]$ mellett

$$
\beta(x) \leq E\left(Y_{1}^{N-1} \vee r\right)
$$

Bizonyítás. Az első egyenlőség éppen az előző lemma, majd parciális integrálással:

$$
\begin{array}{r}
\frac{1}{G(x)}\left(r G(r)+\int_{r}^{x} y g(y) d y\right)=\frac{1}{G(x)}\left(r G(r)+[y G(y)]_{r}^{x}-\int_{r}^{x} G(y) d y\right)= \\
x-\frac{1}{G(x)} \int_{r}^{x} G(y) d y .
\end{array}
$$

A deriváltat számolva:

$$
\begin{aligned}
\beta^{\prime}(x)=\frac{-g(x)}{G^{2}(x)} & \left(r G(r)+\int_{r}^{x} \operatorname{tg}(t) d t\right)+\frac{x g(x)}{G(x)}= \\
& \frac{g(x)}{G(x)}\left(x-\frac{1}{G(x)}\left(r G(r)+\int_{0}^{x} \operatorname{tg}(t) d t\right)\right)=\frac{g(x)}{G(x)}(x-\beta(x)) .
\end{aligned}
$$

A monotonitás szerint minden $x \in[0, \omega]$

$\beta(x)=E\left(Y_{1}^{(N-1)} \vee r \mid Y_{1}^{(N-1)}<x\right) \leq E\left(Y_{1}^{(N-1)} \vee r \mid Y_{1}^{(N-1)}<\omega\right)=E\left(Y_{1}^{(N-1)} \vee r\right)$.

Ezeket kellett belátni.

\subsection{Másodáras aukció}

Másodáras esetben a nyertes a második legnagyobb licit értékét, de legalább a rezervációs árat fizeti. Ha a legnagyobb licit értéke a rezervációs ár alatt marad, akkor minden 
résztvevő vesztes, és a termék a kikiáltónál marad. A játékosok racionalitása az alábbi profit függvény maximalizálását jelenti.

$$
\Pi_{i}= \begin{cases}x_{i}-\max \left\{b_{j}, r: j \neq i\right\} & , \text { ha } b_{i}>\max \left\{b_{j}, r: j \neq i\right\} \\ 0, & \text { egyébként. }\end{cases}
$$

Ugyanúgy, mint eddig, $x_{i}$ jelöli az $i$-edik játékos értékelését; $b_{i}$ az általa leadott licit értékét; és $r$ a rezervációs árat.

3.3. állítás. $A \beta=\mathrm{id}$ vagy a $\beta(x)=x$, ha $x>r$, egyébként $\beta(x)=0$ most is domináns egyensúlyi stratégia.

Bizonyítás. Az 1.5 állítás indoklása mindkét függvényre szó szerint azonos marad.

Ha $x_{1}$ az egyik játékos értékelése, akkor a $\beta(x)$ licittel való nyerés valószínúsége zérus, ha $x_{1}<r$, de $x_{1} \geq r$ esetben ez éppen az $\Omega\left(Y_{1}^{(N-1)}<x\right)$ esemény valószínúsége. Így az egyes játékosok várható befizetése az $r$ rezervációs ár és $x$ értékelés mellett

$$
m(x, r)= \begin{cases}G(x) E\left(Y_{1}^{(N-1)} \vee r \mid Y_{1}^{(N-1)}<x\right), & \text { ha } x \geq r \\ 0, & \text { ha } x<r .\end{cases}
$$

Analitikus formában is megfogalmazhatjuk tehát a várható befizetés értékét az $x$ értékelés és az $r$ rezervációs ár ismeretében.

3.4. állítás. Független azonos eloszlású másodáras aukció esetén a játékosok várható befizetés függvénye

$$
m(x, r)= \begin{cases}r G(r)+\int_{r}^{x} \operatorname{tg}(t) d t, & \text { hax } \geq r, \\ 0, & \text { egyébként } .\end{cases}
$$

\subsection{Elsőáras aukció}

Ha $r \geq 0$ a rezervációs ár, akkor a játék definíciója:

$$
\Pi_{i}= \begin{cases}x_{i}-b_{i} & , \text { ha } b_{i}>\max _{i \neq j} b_{j}, r \\ 0 & , \text { egyébként. }\end{cases}
$$

Az aukció ugyan nem standard, de azért az igaz, hogy $b \geq r$ feltétel mellett a játékos pontosan akkor nyeri az aukciót, ha övé a legnagyobb licit, azaz, ha az 
$\Omega\left(\beta\left(Y_{1}^{(N-1)}\right)<b\right)$ esemény teljesül, amelynek valószínúsége $G\left(\beta^{-1}(b)\right)$. Tehát minden egyes játékos a

$$
\Pi(b, x)= \begin{cases}G\left(\beta^{-1}(b)\right)(x-b), & \text { ha } b \geq r \\ 0, & \text { ha } b<r\end{cases}
$$

kifizetési függvény maximalizálásában érdekelt. Az egyensúlyi stratégia kiszámolása az $r=0$ esethez nagyon hasonló.

3.5. állítás. Szimmetrikus, magán értékelésú, elsőáras aukció r rezervációs ár melletti Nash-egyensúlyi licitfüggvénye a

$$
\beta(x)= \begin{cases}E\left(Y_{1}^{(N-1)} \vee r \mid Y_{1}^{(N-1)}<x\right), & \text { ha } x \geq r \\ 0, & \text { ha } x<r\end{cases}
$$

függvény.

Bizonyítás. Tegyük fel, hogy hogy a $j>1$ játékosok a 3.2 -ben megadott $\beta$ függvénnyel licitálnak. Írjuk fel az 1 játékos várható profitját.

Nézzük azt az esetet, mikor az $x$ értékelésre $x<r$. Ha az 1 játékos $b \geq r$ licitet alkalmaz, akkor esetleg nyer és $x-b<0$ hasznot realizál, ezért profitjára $\Pi(b, x) \leq 0$. A $b<r$ esetben persze $\Pi(b, x)=0$. Ha a $\beta(x)=0$ licitet használja, akkor az aukció definíciója szerint nem nyerhet, profitja tehát ekkor is 0 . Látjuk tehát, hogy $x \leq r$ esetben

$$
\Pi(\beta(x), x)=0 \geq \Pi(b, x) .
$$

Most nézzük az $x \geq r$ esetet. Tegyük fel, hogy a játékos az $x$ értékeléséhez $b$ licitet rendeli.

Ha $b<r$, akkor nem kerül ki az aukcióból nyertesen, tehát $\Pi(b, x)=0$, ezért

$$
\Pi(\beta(x), x) \geq 0=\Pi(b, x) .
$$

Ha $b \geq r$, akkor a $\beta$ függvény monotonitása és $\beta(r)=r$ miatt létezik egyetlen $r \leq z$, amelyre $\beta(z)=b$. Így

$$
\begin{aligned}
& \Pi(b, x)=G\left(\beta^{-1}(b)\right)(x-b)= \\
& G(z)(x-\beta(z))=G(z) x-G(z)\left(z-\frac{1}{G(z)} \int_{r}^{z} G(y) d y\right)= \\
& G(z)(x-z)+\int_{r}^{z} G(y) d y .
\end{aligned}
$$


Speciálisan, ha $b=\beta(x)$, azaz $z=x$, akkor $\Pi(\beta(x), x)=\int_{r}^{x} G(y) d y$. Így

$$
\begin{array}{r}
\Pi(\beta(x), x)-\Pi(b, x)=\int_{r}^{x} G(y) d y+G(z)(z-x)-\int_{r}^{z} G(y) d y= \\
G(z)(z-x)-\int_{x}^{z} G(y) d y \geq 0
\end{array}
$$

az integrál triviális becslése szerint, hiszen $G$ egy monoton növekedő függvény.

Összességében azt mutattuk meg, hogy amennyiben a $j>1$ játékosok mind a $\beta$ függvénnyel licitálnak, akkor az 1 játékos $b \neq \beta(x)$ licitje az ő várható profitját $b=$ $\beta(x)$-hez képest nem növeli.

3.6. állítás. Egyéni értékelésü, azonos eloszlású, elsôáras aukció esetén a játékosok várható befizetés függvénye

$$
m(x, r)= \begin{cases}r G(r)+\int_{r}^{x} \operatorname{tg}(t) d t, & \text { hax } \geq r, \\ 0, & \text { egyébként } .\end{cases}
$$

Bizonyítás. Láttuk, hogy az egyensúlyi licitfüggvény a (3.2)-ben megadott $\beta$-függvény. Ezek szerint az $x \leq r$ értékelés mellett $\beta(x)=0$, így ekkor a várható befizetés is 0 . Ha $x \geq r$, akkor a $\beta(x)$ licittel való nyerés valószínúsége $\beta$ szigorúan monoton volta miatt $G(x)$. Ekkor a szükséges befizetés értéke $\beta(x)$. Ilyen módon továbbra is $x \geq r$-t feltételezve

$$
m(x, r)=G(x) \beta(x)=G(x) \frac{1}{G(x)}\left(r G(r)+\int_{r}^{x} G(y) d y\right) .
$$

Ezt kellett belátni. 



\section{4.}

VIRTUÁLIS ÉRTÉKELÉS 

A 3.6 ÉS A 3.4 ÁLLÍTÁSOKBAN említett ekvivalenciát az alábbi módon is meggondolhatjuk. Próbáljuk meg az 1 játékos $m(x, r)$ várható befizetését értelmezni az optimális licitfüggvények konkrét alakja nélkül is.

Ha $x \leq r$, akkor $m(x, r)=0$, hiszen a játékos inkább veszt, mint negatív profitot kockáztat.

Ha $x>r$, akkor két eset lehetséges. Vagy van a többi játékos közt is olyan, akinek értékelése $r$ felett van vagy nincs.

Ez utóbbi eset valószínúsége $G(r)$, persze 1 nyer és az $r$ rezervációs árat fizeti, akár elsô-, akár másodáras lejátszást követnek. Ez $r G(r)$ várható befizetést eredményez.

Ha van más $r$ feletti értékelésú játékos is, akkor innen az 1 játékos számára az aukció ugyanaz, mintha ő egy rezervációs ár nélküli aukció szereplője lenne, de $X \vee r$ eloszlásokkal, hiszen

$$
\max _{i>1}\left(X_{i} \vee r\right)=\max _{i>1} X_{i}=Y_{1}^{(N-1)} .
$$

Azt már láttuk, hogy a rezervációs ár nélküli esetben az első- és a másodáras aukciónak ugyanaz az ex post várható befizetése. No de, ha $X$ eloszlása $F$, akkor $X \vee r$ eloszlása $F \cdot \chi_{(r, \omega)}$. Ebből következik, hogy a várható befizetés ide eső része

$$
\int_{0}^{x} \operatorname{tg}(t) d t=\int_{r}^{x} \operatorname{tg}(t) d t
$$

Összességében tehát mindkét esetben a várható befizetés a 3.6 és a 3.4 állításokban felírt formula.

\subsection{Valószínúségi változó kockázati rátája}

4.1. definíció (kockázati ráta). Ha az $X$ valószínűségi változó eloszlásfüggvénye $F$ és sűrüségfüggvénye $f$, akkor annak kockázati ráta függvényét

$$
\lambda(x)=\frac{f(x)}{1-F(x)}
$$

definiálja. Itt feltesszük, hogy $F$ folytonosan differenciálható és minden $x \in(0, \omega)$ esetén $F(x)<1$.

A kockázati ráta tehát egy $\lambda:(0, \omega) \rightarrow \mathbb{R}$ folytonos függvény. A feltételes valószínúség definíciója szerint

$$
P(X<r+s \mid X \geq s)=\frac{P(s \leq X<r+s)}{P(X \geq s)}=\frac{\int_{s}^{s+r} f(t) d t}{1-F(s)} .
$$

Tudjuk, hogy van olyan $\xi \in(s, s+r)$, hogy $f(\xi) r=\int_{s}^{s+r} f(t) d t$, ezért, ha $r$ megfelelően kicsi, akkor $f(s) r$ is elég jó becslése az integrálnak. Tehát a kockázati ráta 
függvényre áttérve azt mondhatjuk, hogy

$$
P(X<r+s \mid X \geq s) \approx \lambda(s) r .
$$

Példaként tekintsük az exponenciális eloszlás esetét. Tegyük fel tehát, hogy

$$
F(x)=\left\{\begin{array}{ll}
1-e^{-\lambda x} & , \text { ha } x \geq 0 \\
0 & , \text { egyébként }
\end{array} \quad \text {, így } \quad f(x)= \begin{cases}\lambda e^{-\lambda x} & , \text { ha } x \geq 0 \\
0 & , \text { egyébként. }\end{cases}\right.
$$

A jól ismert örökifjú tulajdonság szerint minden $r, s \geq 0$ esetén $P(X<r+s \mid X \geq s)=$ $P(X<r)$ mindig fennáll, a bal oldal tehát $s$-től független. Használva a kis $X$-ekre hatékony $e^{-x} \approx 1-x$ becslést,

$$
P(X<r+s \mid X \geq s)=P(X<r)=1-e^{-\lambda r} \approx \lambda r .
$$

Ennek megfelelóen az exponenciális eloszlás kockázati rátájára

$$
\lambda(s)=\frac{f(s)}{1-F(s)}=\frac{\lambda e^{-\lambda s}}{e^{-\lambda s}}=\lambda
$$

konstans függvény. Arról van tehát szó, hogy az exponenciális eloszlás esetében az shez közeli teljesülésnek az $s$ időpontig nem teljesülés feltétele melletti valószínúsége annak az intervallumnak a hosszával arányos, amellyel az $s$-hez közeli teljesülést mérjük. A lényeg, hogy itt az arányossági tényező az $s$ időponttól független, mert minden $s$ mellett éppen azonos az eloszlás paraméterével. Ez az exponenciális eloszlás örökifjú tulajdonsága. Más eloszlásokra $P(X<s+r \mid X \geq s)$ még kicsi $r$ mellett is függhet $s$-tôl, de az exponenciális eloszlás örökifjú tulajdonságából annyi minden eloszlásra átmenthetô, hogy az $(s, s+r)$ kis intervallumban való teljesülésnek az $s$-ig nem teljesülés feltétele melletti valószínúsége közelítőleg

$$
\lambda(s) r
$$

tehát ez is az intervallumocska $r$ hosszával arányos, de esetleg $s$-tôl függő $\lambda(s)$ arányossági tényezővel.

4.2. állítás. Tegyük fel, hogy az $X$ valószínúségi változó eloszlására minden $x \in(0, \omega)$ mellett $0<F(x)<1, F$ szigorúan monoton növó és folytonosan differenciálható. Legyen $\lambda:(0, \omega) \rightarrow \mathbb{R}_{+}$a kockázati ráta függvény. Ekkor $\lambda$ folytonos és minden $x \in(0, \omega)$ mellett

$$
F(x)=1-e^{-\int_{0}^{x} \lambda(t) d t} .
$$

Megfordítva, ha $\lambda:(0, \omega) \rightarrow \mathbb{R}_{+}$tetszóleges pozitív, folytonos függvény, amelyre

$$
\int_{0}^{\omega} \lambda(t) d t=\infty, d e \int_{0}^{x} \lambda(t) d t<\infty, \forall x \in(0, \omega)
$$

teljesül, úgy a fenti $(\dagger)$ definiálta függvény egy folytonosan differenciálható, szigorúan monoton növó eloszlás függvény a $[0, \omega]-n$, ergo van olyan $X$ valószínúségi változó, 
aminek éppen $F$ az eloszlása. Ennek a valószínúségi változónak a kockázati rátája éppen az elöre megadott $\lambda$, továbbá

$$
E(X)=E\left(\frac{1}{\lambda(X)}\right)
$$

\subsection{A kikiáltó bevétele a rezervációs ár függvényében}

Az egész szakaszban tegyük fel, hogy a játékosok értékelését leíró $F$ eloszlás folytonosan differenciálható, és szigorúan monoton növő. Ekkor persze $0<F(x)<1$ tetszőleges $x \in[0, \omega]$ mellett.

A 3.4 és a 3.6 állításokban láttuk, hogy a játékosok befizetési függvénye mind első, mind másodáras aukció esetében a rezervációs ár jelenléte mellett is azonos. Ennek segítségével most is könnyư kiszámolni a várható befizetés értékét.

4.3. lemma. Rögzített $r \geq 0$ rezervációs ár mellett az elsó- vagy a másodáras aukcióban résztvevố játékosok várható befizetésének értéke

$$
E(m(X, r))=r(1-F(r)) G(r)+\int_{r}^{\omega} y(1-F(y)) g(y) d y .
$$

E függvény r szerinti deriváltfüggvénye

$$
\frac{d}{d x} E(m(X, r))=G(r)(1-F(r))(1-r \lambda(r)),
$$

ahol $\lambda$ az eloszlások kockázati ráta függvénye, azaz $\lambda(r)=\frac{f(r)}{1-F(r)}$.

Bizonyítás. A valószínúségi változó transzformáltjára vonatkozó formula szerint

$$
\begin{gathered}
E(m(X, r))=\int_{0}^{\omega} m(x) f(x) d x= \\
\int_{r}^{\omega}\left(r G(r)+\int_{r}^{x} \operatorname{tg}(t) d t\right) f(x) d x=\int_{r}^{\omega} r G(r) f(x) d x+\int_{r}^{\omega} \int_{r}^{x} \operatorname{tg}(t) f(x) d t d x .
\end{gathered}
$$

Persze

$$
\int_{r}^{x} \operatorname{tg}(t) f(x) d t=\int_{r}^{\omega} \chi_{[r, x]}(t) \operatorname{tg}(t) f(x) d t=\int_{r}^{\omega} \chi_{[t, \omega]}(x) \operatorname{tg}(t) f(x) d t,
$$


emiatt, folytatva az $E(m(X, r))$ kiszámítását, a Fubini-tétel szokásos használatával

$$
\begin{gathered}
E(m(X, r))=\int_{r}^{\omega} r G(r) f(x) d x+\int_{r}^{\omega} \int_{r}^{\omega} \chi_{[t, \omega]}(x) \operatorname{tg}(t) f(x) d t d x= \\
r G(r)(1-F(r))+\int_{r}^{\omega} \int_{r}^{\omega} \chi_{[t, \omega]}(x) f(x) \operatorname{tg}(t) d x d t= \\
r G(r)(1-F(r))+\int_{r}^{\omega}\left(\int_{t}^{\omega} f(x) d x\right) \operatorname{tg}(t) d t= \\
r G(r)(1-F(r))+\int_{r}^{\omega}(1-F(t)) \operatorname{tg}(t) d t .
\end{gathered}
$$

Most számoljuk ki a fenti függvény $r$ szerinti deriváltját.

$$
\begin{aligned}
& G(r)(1-F(r))+r g(r)(1-F(r))-r G(r) f(r)-(1-F(r)) r g(r)= \\
& G(r)(1-F(r))-r G(r)(1-F(r)) \lambda(r)=G(r)(1-F(r))(1-r \lambda(r)) .
\end{aligned}
$$

4.4. állítás. Tegyük fel, hogy a kockázati ráta függvényt a 0 egy jobb oldali környezetében majorálja az $\frac{1}{t}$ függvény, azaz létezik $\delta>0$, melyre $\lambda(t)<\frac{1}{t}$ fennáll minden $t \in(0, \delta)$ mellett. Tekintsük a kikiáltó várható bevételét egy elsó- vagy másodáras aukcióban mint a rezervációs ár függvényét. Ekkor e függvény a 0 fenti környezetében szigorúan monoton növó, ergo $r=0$ nem lehet optimális rezervációs ár.

Most tekintsük a fenti problémát egy kicsit általánosabb esetben. Tegyük fel, hogy a kikiáltó is rendelkezik egy $x_{0}$ értékeléssel. A feladata, hogy állítson be olyan rezervációs árat, amely a várható profitját maximalizálja. Teljesen világos, hogy $r<x_{0}$ rezervációs ár használata esetleg negatív haszonnal jár, ezért a továbbiakban feltehetô, hogy $x_{0} \leq r$ teljesül. Írjuk fel a kikiáltó várható profitját az általa beállítandó rezervációs ár függvényében:

$$
\Pi(r)=N E(m(X, r))+F(r)^{N} x_{0} .
$$

A kikiáltó várható bevétele a játékosok várható befizetéseinek összege, ami az elsô tag, és sikertelen aukció esetén a tárgy további birtoklásából eredő haszon várható értéke. Mivel az aukció $F^{N}(r)$ valószínúséggel sikertelen, ezért az ebből eredő haszon várható értéke $x_{0}$ értékelés mellett $F^{N}(r) \cdot x_{0}$.

E függvény $r$ szerinti derivált függvényére:

$$
\begin{gathered}
(\Pi(r))^{\prime}=N E(m(X, r))^{\prime}+N F(r)^{N-1} f(r) x_{0}= \\
N G(r)(1-F(r))(1-r \lambda(r))+N G(r) \lambda(r)(1-F(r)) x_{0}= \\
N G(r)(1-F(r))\left(1-r \lambda(r)+\lambda(r) x_{0}\right)=N G(r)(1-F(r))\left(1-\lambda(r)\left(r-x_{0}\right)\right) .
\end{gathered}
$$

Ha kizárjuk az $F\left(x_{0}\right)=1$ és az $F\left(x_{0}\right)=0$ eseteket, akkor azt kapjuk, hogy a fenti profit függvény az $x_{0}$ pont egy jobb oldali környezetében szigorúan monoton növő, így $r=x_{0}$ 
biztosan nem optimális a kikiáltó várható profitja szempontjából. Az is nyilvánvaló, hogy az optimális $r$ rezervációs árra az

$$
x_{0}=r-\frac{1}{\lambda(r)}
$$

implicit egyenletnek kell teljesülnie.

Fontos, de nyilvánvaló következménye a fentieknek, hogy az optimális rezervációs ár független az aukcióban résztvevő játékosok számától.

Egyszerú példaként, írjuk fel az optimális rezervációs árat mint a kikiáltó $x_{0}$ értékelésének függvényét abban a speciális esetben, mikor a játékosok értékelése egyenletes eloszlás szerint történik. Kis számolgatás után azt kapjuk, hogy

$$
r=\frac{x_{0}}{2}+\frac{1}{2}
$$

az optimális rezervációs ár.

Ugyanezt általában is megtehetjük:

4.5. definíció (virtuális értékelés). Legyen a játékosok értékelésének eloszlása $F$ és ennek tartója $[0, \omega]$. Definiálja a $\psi:(0, \omega) \rightarrow \mathbb{R}$ az alábbi függvényt.

$$
\psi(x)=x-\frac{1}{\lambda(x)}=x-\frac{1-F(x)}{f(x)} .
$$

A $\psi$ függvényt a játékosok virtuális értékelésének mondjuk.

4.6. definíció (reguláris játékos). Az aukcióban résztvevő játékost regulárisnak mondjuk, ha virtuális értékelése szigorúan monoton növő.

4.7. állítás. Ha $\psi$ a reguláris játékosok virtuális értékelése és a kikiáltó számára a tárgy birtoklása $x_{0}$ értéket jelent, akkor

$$
\psi^{-1}\left(x_{0}\right)
$$

éppen a kikiáltó várható bevételét maximalizáló rezervációs árat adja meg.

Könnyed számolgatással kapjuk például, hogy ha a játékosok értékelése a $[0, \omega]$ intervallumon egyenletes eloszlású, akkor a kikiáltó $x_{0}$ értékeléséhez tartozó rezervációs árra a

$$
\psi^{-1}\left(x_{0}\right)=\frac{1}{2} x_{0}+\frac{1}{2} \omega
$$

formula adódik. 


\subsection{A kikiáltó mint monopolista}

Az optimális rezervációs ár egy másik értelmezése a következó gondolatkísérlet. Tegyük fel, hogy a kikiáltó $p$ rezervációs árat ajánl, és az $i$-edik vevő ezt ismeri. Az $i$-edik vevő tisztában van a maga $x_{i}$ értékelésével, és ha nem lenne aukció akkor $x_{i}>p$ esetben a tárgyat $p$ áron biztosan megvenné. A kikiáltó persze nem ismeri az $i$-edik játékos konkrét értékelését, csak az értékelésének $F_{i}$ eloszlását. Azt tudja tehát a kikiáltó, hogy ha ô $p$ árat ajánl, akkor az üzlet valószínúsége az $X_{i}>p$ esemény valószínúsége, ergo $1-F_{i}(p)$. Innen a kikiáltó számára a helyzet ugyanaz, mintha az ő monopóliuma lenne a termék eladása, és a vevők keresleti függvénye lenne a

$$
q(p)=1-F_{i}(p) .
$$

Így a tárgy eladásából származó várható haszon a kikiáltó mint monopolista számára

$$
p q(p)
$$

Ha most $x_{0}$ jelöli a kikiáltó számára a tárgy birtoklásából eredő hasznot, akkor bevétele a $p$ ár függvényében

$$
R(p)=p\left(1-F_{i}(p)\right)+F_{i}(p) x_{0}
$$

Persze a marginális bevétele

$$
\begin{array}{r}
R^{\prime}(p)=1-F_{i}(p)-p f_{i}(p)+f_{i}(p) x_{0}=f_{i}(p)\left(x_{0}-\left(p-\frac{1-F_{i}(p)}{f_{i}(p)}\right)\right)= \\
f_{i}(p)\left(x_{0}-\psi_{i}(p)\right) .
\end{array}
$$

Azt kaptuk tehát, hogy a monopolista kikiáltó optimális árára a

$$
\psi_{i}(p)=x_{0}
$$

egyenlőség teljesül.

Ezek szerint a reguláris játékosokkal szemben álló kikiáltónak olyan $p$ rezervációs árat érdemes megállapítania, amely - ugyanazokkal a játékosokkal szemben állva mint monopolistának az optimális bevételét eredményezné a $p$ eladási árat alkalmazva.

Ha feltesszük, hogy a játékosok értékelése egyenletes eloszlású, vagy exponenciális eloszlású, akkor a kikiáltó zérus értékeléséhez tartozó rezervációs ár éppen az eloszlások várható értéke. Igaz-e ez minden más eloszlásra is? Próbáljuk meg leírni eloszlások egy osztályát, amikor mégis igaz a fenti sejtés. Hasonlóan, mely eloszlásokra lesz az optimális rezervációs ár a várhatóérték felett, és mely eloszlásokra marad alatta 1

\footnotetext{
${ }^{1} \mathrm{Ha} r^{*}$ az optimális rezervációs ár, akkor $\psi\left(r^{*}\right)=0=E\left(X-\frac{1}{\lambda(X)}\right)=E(\psi \circ X)=\psi(E(X))$, ha a $\psi$ virtuális értékelés $t \mapsto a t+b$ alakú, és emiatt persze $r^{*}=E(X)$. Ez a helyzet, ha az értékelések eloszlása például exponenciális vagy egyenletes. A Jensen-egyenlőtlenséget alkalmazva látszik, hogy ha $\psi$ szigorúan monoton nó és konvex, akkor $r^{*} \leq E(X)$. Hasonlóan, a konkáv virtuális értékelés esetén $E(X) \leq r^{*}$.
} 


\subsection{Belépési díj}

Azt láttuk az előző fejezetben, hogy a rezervációs ár bevezetésével a kikiáltó növelni tudja várható bevételét. Végül is ezt avval éri el, hogy távol tartja az aukciótól azon játékosokat, akiknek licitje a rezervációs ár alatt van.

Szokásos távol tartó eljárás még a belépési díj bevezetése. Azt kell ezen érteni, hogy a kikiáltó meghatároz egy fix és mindenki más által ismert összeget, amit az aukció minden résztvevőjének be kell fizetni. Gondolhatunk egyszerúen például a ruhatár költségére.

Gondoljunk vissza az $r$ rezervációs ár melletti várható befizetés függvényére. Láttuk a 3.4 és a 3.6 állításokban, hogy mindkét eddig tárgyalt árverési formában ez a függvény

$$
m(x, r)= \begin{cases}r G(r)+\int_{r}^{x} \operatorname{tg}(t) d t, & \text { ha } x \geq r, \\ 0, & \text { egyébként. }\end{cases}
$$

Ebből azonnal látszik, hogy az $r$ rezervációs ár melletti aukcióból pontosan azokat a játékosokat zárjuk ki, akiknek értékelése $r$ alatt, ergo a várható befizetése az

$$
m(r, r)=r G(r)
$$

érték alatt marad. Ahhoz tehát, hogy a belépési ár bevezetésével pontosan ugyanazon játékosok kényszerüljenek az aukcióban részt nem venni, az

$$
e=r G(r)
$$

belépési árat kell meghatároznunk. Világos ugyanis, hogy a belépési ár melletti aukcióban egy, az árat megfizető játékos befizetési függvénye legalább $e$.

Most írjuk fel $e=r G(r)$ belépési ár mellett a várható befizetés függvényt. Nézzük az egyszerűség kedvéért a másodáras aukció esetét. Látható, hogy $x \geq r$ esetben a játékos megfizeti az $e$ belépési díjat és a további várható befizetése a nyerés valószínúsége szorozva a második legnagyobb, de a belépési árat megfizetô értékelésnek a nyerés feltétele melletti várható értékével.

$$
m(x, e)=e+G(x) \frac{1}{G(x)} \int_{r}^{x} \operatorname{tg}(t) d t .
$$

A fenti integrál valóban csak $r$-tôl indul, hiszen 1 játékos számára csak a második legnagyobb, de $r$ feletti értékelés jelenthet esetleges fizetési kötelezettséget.

Megmutattuk tehát az alábbi állítást.

4.8. állítás. Egyéni értékelésü, azonos eloszlású valószinûségi változókkal játszott, $r$ rezervációs áras elsó- vagy másodáras aukció várható befizetési függvénye azonos az. $r G(r)$ belépési árat meghatározó elsó- vagy másodáras aukción várható befizetésével. Ilyen módon az $r$ rezervációs ár mellett a kikiáltó várható haszna azonos az $r G(r)$ belépési ár melletti várható haszonnal. 


TEKINTSÜK A JÁTÉKOS profitfüggvényét. A lényeg, hogy a várható profit értéke felírható az optimális licitfüggvény aktuális értékétől függetlenül is. Világos, hogy a várható bevétel a nyerés valószínúségének és az aktuális értékelésnek a szorzata. Ha a feltételezett $\beta$ szigorúan monoton, akkor a legnagyobb értékelésú játékos nyer, hiszen standard aukcióról van szó. Ha tehát $b$ a leadott licit, akkor $G\left(\beta^{-1}(b)\right)$ a $b$ licittel való nyerés valószínúsége. Tegyük fel most, hogy a várható befizetési függvény adott. Ekkor az $x$ értékeléssel és a $b$ licittel együtt járó várható bevétel a

$$
\Pi(b, x)=G\left(\beta^{-1}(b)\right) x-m\left(\beta^{-1}(b)\right),
$$

amint azt $\left(\Pi^{\star}\right)$ indoklásakor láttuk.

Ha most $\beta$ optimális licitfüggvény, az azt jelenti, hogy játékosunk fent számított várható profitja $b=\beta(x)$-ben maximumon van. Ez azt jelenti, hogy tetszőlegesen rögzített $x$ értékelés mellett a fenti profitfüggvény első változó szerint deriváltja $b=\beta(x)$ pontban zérus, azaz $\partial_{1} \Pi(\beta(x), x)=0$. Persze

$$
\partial_{1} \Pi(b, x)=g\left(\beta^{-1}(b)\right) \frac{1}{\beta^{\prime}\left(\beta^{-1}(b)\right)} x-m^{\prime}\left(\beta^{-1}(b)\right) \frac{1}{\beta^{\prime}\left(\beta^{-1}(b)\right)} .
$$

Ha tehát $b=\beta(x)$, akkor

$$
g(x) \frac{1}{\beta^{\prime}(x)} x-m^{\prime}(x) \frac{1}{\beta^{\prime}(x)}=0 .
$$

Azt kapjuk tehát, hogy minden $x$ értékelés mellett $m^{\prime}(x)=x g(x)$, így a NewtonLeibnitz-tétel szerint explicit formulát kapunk a befizetési függvényre: $m(x)=m(0)+$ $\int_{0}^{x} \operatorname{tg}(t) d t$. Az alábbi tételt igazoltuk.

5.1. állítás (bevételekvivalencia-elv). Tegyük fel, hogy szimmetrikus modellben játszott, standard aukciót a felek szigorúan monoton növö licitfüggvénnyel játsszák szimmetrikus Nash-egyensúlyi helyzetben.

Ekkor a várható befizetési függvény független az aukció szerkesztésétól és felírható a használt licitfüggvénytôl függetlenül. Konkrét alakja:

$$
m(x)=m(0)+\int_{0}^{x} \operatorname{tg}(t) d t .
$$

\subsection{Speciális aukciók}

Az eddigiekben az $m$ befizetési függvényt a konkrét $\beta$ licitfüggvény alakjából származtattuk. A bevételekvivalencia-elv fontos következménye, hogy $m$ a standard aukció 
lejátszási módjától független. Ez lehetőséget ad az optimális licitfüggvény meghatározására is. Tegyük fel például, hogy nem ismerjük az elsőáras aukció optimális licitfüggvényét. Világos, hogy elsőáras esetben

$$
m(x)=G(x) \beta(x),
$$

hiszen $G(x)$ az $x$ értékelésú játékos nyerésének valószínúsége és a nyertes a $\beta(x)$ licitjét köteles fizetni. Ebből azonnal adódik a már korábban kiszámított

$$
\beta(x)=\frac{1}{G(x)} \int_{0}^{x} \operatorname{tg}(t) d t=E\left(Y_{1}^{(N-1)} \mid Y_{1}^{(N-1)}<x\right)
$$

formula.

Hasonló ötlettel nézzük a másodáras aukciók esetét. Feledjük el egy pillanatra, hogy az id függvény adja az optimális liciteket. Az aukció lejátszási módja szerint

$$
m(x)=G(x) E\left(\beta\left(Y_{1}^{(N-1)}\right) \mid Y_{1}^{(N-1)}<x\right) .
$$

Jelölje $F_{1}^{(N-1)}\left(\cdot \mid Y_{1}^{(N-1)}<x\right)$ az $Y_{1}^{(N-1)}$ valószínúségi változónak az $Y_{1}^{(N-1)}<x$ esemény melletti feltételes eloszlás függvényét. Ekkor minden $t<x$ mellett

$$
F_{1}^{(N-1)}\left(t \mid Y_{1}^{(N-1)}<x\right)=\frac{P\left(\left(Y_{1}^{(N-1)}<t\right) \cap\left(Y_{1}^{(N-1)}<x\right)\right)}{P\left(Y_{1}^{(N-1)}<x\right)}=\frac{G(t)}{G(x)} .
$$

Így a feltételes eloszlásra azt kapjuk, hogy

$$
f_{1}^{(N-1)}\left(t \mid Y_{1}^{(N-1)}<x\right)=\frac{g(t)}{G(x)} .
$$

Ilyen módon bármi is a $\beta$ licitfüggvény, de

$$
E\left(\beta\left(Y_{1}^{(N-1)}\right) \mid Y_{1}^{(N-1)}<x\right)=\int_{0}^{x} \frac{g(t)}{G(x)} \beta(t) d t .
$$

A bevételekvivalencia-elv szerint

$$
\int_{0}^{x} \operatorname{tg}(t) d t=m(x)=G(x) E\left(\beta\left(Y_{1}^{(N-1)}\right) \mid Y_{1}^{(N-1)}<x\right)=\int_{0}^{x} \beta(t) g(t) d t
$$

teljesül minden $x$ mellett, amiből egy deriválás után $\beta=$ id valóban következik.

A fenti két példa semmi újat nem adott, hiszen korábban meghatároztuk már az elsôés másodáras aukció optimális licitfüggvényeit. Viszont azt látjuk, hogy kiindulva valamely konkrét aukció lejátszási módjából, ha az $m$ befizetési függvény és a $\beta$ licitfüggvény között kapcsolatot tudunk létesíteni, akkor a bevételekvivalencia-elv lehetôséget ad az optimális licitfüggvény analitikus felírására. 


\section{Mindenki fizet aukció}

A lejátszás a következő. A legnagyobb licitet ajánló játékos nyer, de mindenki fizeti az általa megtett licitet, függetlenül attól, hogy nyert vagy sem. Az i-edik játékos tehát a

$$
\Pi_{i}= \begin{cases}x-b_{i} & , \text { ha } b_{i}>\max _{j \neq i} b_{j} \\ -b_{i} & , \text { egyébként }\end{cases}
$$

függvény maximalizálására törekszik. Most tegyük fel, hogy van $\beta$ szigorúan monoton növő optimális licitfüggvény. Ekkor a bevételekvivalencia-elv szerint az $x$ értékeléssel együtt járó várható befizetés

$$
\int_{0}^{x} \operatorname{tg}(t) d t=m(x)=\beta(x) .
$$

Azt kaptuk tehát, hogy az optimális licitfüggvény csak a fenti alakú lehet. Itt könnyú igazolni, hogy a fenti $\beta$ valóban az optimális licitfüggvény. Bevezetve a $z=\beta^{-1}(x)$ jelölést azt kapjuk, hogy

$$
\begin{array}{r}
\Pi(b, x)=G\left(\beta^{-1}(b)\right) x-b= \\
G(z) x-\beta(z)=G(z) x-\int_{0}^{z} t g(t) d t=G(z) x-z G(z)+\int_{0}^{z} G(t) d t= \\
G(z)(x-z)+\int_{0}^{z} G(t) d t .
\end{array}
$$

Speciálisan, ha $b=\beta(x)$, azaz $z=x$, akkor

$$
\Pi(\beta(x), x)=\int_{0}^{x} G(t) d t .
$$

Így hasonlóan a korábbiakhoz

$$
\begin{aligned}
\Pi(\beta(x), x)-\Pi(b, x)=\int_{0}^{x} G(t) d t+G(z)(z-x)-\int_{0}^{z} G(t) d t & = \\
& G(z)(z-x)-\int_{x}^{z} G(t) d t \geq 0
\end{aligned}
$$

a $G$ monoton növekedése szerint. Bebizonyítottuk tehát az alábbi állítást.

5.2. állítás. A mindenki fizet aukciónak létezik szigorúan monoton növö optimális licitfüggvénye. Ennek analitikus alakja

$$
\beta^{A P}(x)=\int_{0}^{x} \operatorname{tg}(t) d t=G(x) E\left(Y_{1}^{(N-1)} \mid Y_{1}^{(N-1)}<x\right) .
$$




\section{Vesztesek fizetnek aukció}

A lejátszás definíciója szerint a legnagyobb licitet bejelentő játékos az aukció nyertese. Minden játékos befizeti az általa ajánlott licitet, kivéve a nyertes játékos, aki nem fizet semmit. Magyarul:

$$
\Pi_{i}= \begin{cases}x & , \text { ha } b_{i}>\max _{j \neq i} b_{j} \\ -b_{i} & , \text { egyébként. }\end{cases}
$$

Kapcsolatot kell teremtenünk a licitfüggvény és a várható befizetés között. Látható, hogy ez a kapcsolat:

$$
m(x)=(1-G(x)) \beta(x),
$$

hiszen a vesztés valószínúsége szorozva a vesztéskor fizetendő értékkel. A bevételekvivalencia-elv szerint

$$
(1-G(x)) \beta(x)=\int_{0}^{x} \operatorname{tg}(t) d t .
$$

Bebizonyítottuk tehát az alábbi állítást.

5.3. állítás. Az vesztesek fizetnek aukció szigorúan monoton, optimális licitfüggvénye egyedül a

$$
\beta^{L P}(x)=\frac{1}{1-G(x)} \int_{0}^{x} \operatorname{tg}(t) d t=\frac{G(x)}{1-G(x)} E\left(Y_{1}^{(N-1)} \mid Y_{1}^{(N-1)}<x\right)
$$

licitfüggvény lehet.

\section{Kivéreztetés}

Csak $N=2$ esetben tudjuk a feladatot megoldani. A legnagyobb licitet adó játékos nyer, mindketten fizetik a vesztes által leadott licitet. Ha a játékosok $i$ és $j$, akkor

$$
\Pi_{i}= \begin{cases}x-b_{j} & , \text { ha } b_{i}>b_{j} \\ -b_{i} & , \text { egyébként. }\end{cases}
$$

Tehát vesztés esetén a saját licit, nyerés esetén a második legnagyobb licit fizetendő. Ez azt jelenti, hogy a várható befizetés:

$$
m(x)=(1-G(x)) \beta(x)+G(x) E\left(\beta\left(Y_{1}^{(N-1)}\right) \mid Y_{1}^{(N-1)}<x\right) .
$$

Felhasználva a (5.1) formulát, a bevételekvivalencia-elv szerint

$$
\int_{0}^{x} \operatorname{tg}(t) d t=(1-G(x)) \beta(x)+\int_{0}^{x} g(t) \beta(t) d t .
$$

Felírva a deriváltakat azt kapjuk, hogy

$$
x g(x)=-g(x) \beta(x)+(1-G(x)) \beta^{\prime}(x)+g(x) \beta(x)=(1-G(x)) \beta^{\prime}(x) .
$$


Innen persze azt kapjuk, hogy az optimális licitfüggvénynek ki kell elégítenie a

$$
\beta^{\prime}(x)=\frac{g(x)}{(1-G(x))} x
$$

egyenletet. Persze ez $N=2$ miatt $\frac{x}{1-x}=\frac{1}{1-x}-1$ függvényt jelenti. Bebizonyítottuk tehát a következő állítást:

5.4. állítás. A kivéreztetés (,war of attrition”) aukció optimális licitfüggvényére az $N=2$ esetben csak $a$

$$
\beta^{W A}(x)=\int_{0}^{x} \frac{\operatorname{tg}(t)}{1-G(t)} d t
$$

formula lehetséges.

\section{Harmadáras aukció}

Újra tetszőleges $N$ mellett vizsgáljuk a jelenséget, persze $N \geq 3$. A harmadáras aukció majdnem mindenben azonos a másodárassal, de most a nyerő befizetés a harmadik legnagyobb ajánlott licit. Tehát az $i$-edik játékos szempontjából:

$$
\Pi_{i}= \begin{cases}x-\max 2_{j \neq i} b_{j} & , \text { ha } b_{i}>\max _{j \neq i} b_{j}, \\ 0 & , \text { egyébként. }\end{cases}
$$

Nyilvánvaló, hogy a befizetési függvény és a licitfüggvény közti kapcsolat:

$$
m(x)=G(x) E\left(Y_{2}^{(N-1)} \mid Y_{1}^{(N-1)}<x\right) .
$$

Azért, hogy a fenti feltételes várható értéket könnyen kezeljük, számítsuk ki először a feltételes súrúségfüggvényt. Jelölje a továbbiakban $F_{1}^{(N-1)}$ az $Y_{1}^{(N-1)}$ eloszlását, és $F_{2}^{(N-1)}$ az $Y_{2}^{(N-1)}$ valószínúségi változó eloszlását. Hasonlóan $F_{1}^{(N-1)}(\cdot \mid A)$ az $Y_{1}^{(N-1)}$ feltételes eloszlását az $A$ feltételi esemény mellett, és $F_{2}^{(N-1)}(\cdot \mid A)$ az $Y_{2}^{(N-1)}$ feltételes eloszlásfüggvénye. Analóg módon $f_{1}^{(N-1)}, f_{2}^{(N-1)}$ az $Y_{1}^{(N-1)}$ és $Y_{2}^{(N-1)}$ sûrúségfüggvénye. A feltételes sûrűségfüggvények: $f_{2}^{(N-1)}(\cdot \mid A)$ az $Y_{2}^{(N-1)}$ valószínúségi változó és $f_{1}^{(N-1)}(\cdot \mid A)$ az $Y_{1}^{(N-1)}$ valószínúségi változó feltételes sûrûségfüggvénye az $A$ feltétel mellett. Korábban azt láttuk, hogy $f_{1}^{(N-1)}\left(t \mid Y_{1}^{(N-1)}<x\right)=\frac{g(t)}{G(x)}$.

5.5. lemma. $A z Y_{2}^{(N-1)}$ valószínúségi változónak az $Y_{1}^{(N-1)}<x$ feltétel melletti feltételes sürüségfüggvényére

$$
f_{2}^{(N-1)}\left(y \mid Y_{1}^{(N-1)}<x\right)=\frac{1}{F_{1}^{(N-1)}(x)}(N-1)(F(x)-F(y)) f_{1}^{(N-2)}(y)
$$

minden $y<x$ mellett. 
Bizonyítás. Világos, hogy $y<x$ mellett

$$
\begin{aligned}
\left(Y_{2}^{(N-1)}<y\right) \cap\left(Y_{1}^{(N-1)}<x\right) & = \\
& \left(Y_{1}^{(N-1)}<y\right) \cup\left(\left(y \leq Y_{1}^{(N-1)}<x\right) \cap\left(Y_{2}^{(N-1)}<y\right)\right),
\end{aligned}
$$

egymást kizáró értelemben. Ez utóbbi esemény csak úgy teljesülhet, hogy az $X_{1}, \ldots, X_{N-1}$ valószínúségi változók egyike esik az $[y, x)$ intervallumba, míg az összes többi a $[0, y]$ intervallumban marad. No de az előbbi $N-1$ féleképpen lehetséges, így ennek valószínúsége $(N-1)(F(x)-F(y))$, persze az utóbbi esemény valószínúsége $F_{1}^{(N-2)}(y)$. Így

$$
P\left(\left(Y_{2}^{(N-1)}<y\right) \cap\left(Y_{1}^{(N-1)}<x\right)\right)=F_{1}^{(N-1)}(y)+(N-1)(F(x)-F(y)) F_{1}^{(N-2)}(y) .
$$

A feltételes valószínúség definíciója miatt

$$
F_{2}^{(N-1)}\left(y \mid Y_{1}^{(N-1)}<x\right)=\frac{1}{F_{1}^{(N-1)}(x)}\left(F_{1}^{(N-1)}(y)+(N-1)(F(x)-F(y)) F_{1}^{(N-2)}(y)\right) .
$$

Ezt $y$ szerint deriválva kapjuk a szóban forgó feltételes sûrûségfüggvényt:

$$
\begin{aligned}
& f_{2}^{(N-1)}\left(y \mid Y_{1}^{(N-1)}<x\right)= \\
& \frac{1}{F_{1}^{(N-1)}(x)}\left(f_{1}^{(N-1)}(y)+(N-1)\left(-f(y) F_{1}^{(N-2)}(y)+(F(x)-F(y)) f_{1}^{(N-2)}(y)\right)\right) .
\end{aligned}
$$

Most vegyük észre, hogy a középen szereplő

$$
(N-1)(-f) F_{1}^{(N-2)}=(N-1)(-f) F^{N-2}=-\left(F^{N-1}\right)^{\prime}=-\left(F_{1}^{(N-1)}\right)^{\prime}=-f_{1}^{(N-1)} \text {. }
$$

Ezt kellett belátni.

Visszatérve a befizetési függvényre

$$
\begin{gathered}
m(x)=G(x) E\left(\beta\left(Y_{2}^{(N-1)}\right) \mid Y_{1}^{(N-1)}<x\right)= \\
G(x) \int_{0}^{x} f_{2}^{(N-1)}\left(t \mid Y_{1}^{(N-1)}<x\right) \beta(t) d t=(N-1) \int_{0}^{x}(F(x)-F(t)) f_{1}^{(N-2)}(t) \beta(t) d t= \\
(N-1)\left(F(x) \int_{0}^{x} f_{1}^{(N-2)}(t) \beta(t) d t-\int_{0}^{x} F(t) f_{1}^{(N-2)}(t) \beta(t) d t\right) .
\end{gathered}
$$

A bevételekvivalencia-elv szerint e függvény deriváltja éppen $x g(x)$. Tehát

$$
\begin{array}{r}
m^{\prime}(x)= \\
(N-1)\left(f(x) \int_{0}^{x} f_{1}^{(N-2)}(t) \beta(t) d t+F(x) f_{1}^{(N-2)}(x) \beta(x)-F(x) f_{1}^{(N-2)}(x) \beta(x)\right)= \\
(N-1) f(x) \int_{0}^{x} f_{1}^{(N-2)}(t) \beta(t) d t .
\end{array}
$$


Emlékezzünk arra, hogy $g=\left(F^{N-1}\right)^{\prime}=(N-1) F^{N-2} f=(N-1) F_{1}^{(N-2)} f$. Így a bevételekvivalencia-elv miatt minden $x$ értékelés mellett

$$
x g(x)=x(N-1) F_{1}^{(N-2)}(x) f(x)=(N-1) f(x) \int_{0}^{x} f_{1}^{(N-2)}(t) \beta(t) d t=m^{\prime}(x),
$$

amiből a középső egyenlőség egyszerúsítése után kapjuk az

$$
x F_{1}^{(N-2)}(x)=\int_{0}^{x} f_{1}^{(N-2)}(t) \beta(t) d t
$$

azonosságot. Világos, hogy innen $\beta$ egy újbóli deriválás után már kifejezhető:

$$
F_{1}^{(N-2)}(x)+x f_{1}^{(N-2)}(x)=f_{1}^{(N-2)}(x) \beta(x),
$$

amiből már $\beta$ explicit alakban adódik.

$$
\beta(x)=x+\frac{F_{1}^{(N-2)}(x)}{f_{1}^{(N-2)}(x)}=x+\frac{F^{N-2}(x)}{(N-2) F^{N-3}(x) f(x)}=x+\frac{F(x)}{(N-2) f(x)} .
$$

Itt meg is fogalmazhatnánk, hogy csak a fenti alakú függvény lehet a harmadáras aukció optimális licitfüggvénye.

A probléma viszont a következő. A bevételekvivalencia-elv alkalmazhatóságának egyik feltétele volt a szigorúan monoton növő licitfüggvény létének feltételezése. Ahhoz tehát, hogy olyan állítást gyártsunk, amelynek feltételrendszere legalábbis nem biztosan üres, ahhoz szükséges valamilyen feltétel, ami garantálja a fenti $\beta$ monoton növekedését. A legjobb lenne persze szükséges és elégséges feltétel. Viszont szép feltétel adható a $\frac{F}{f}$ függvény monotonitására, ezért ez a feltétel megfelelő, de csak elégséges feltételt ad a fenti alakú $\beta$ függvény monotonitására.

Tegyük fel, hogy az $F$ eloszlás logaritmikusan konkáv. Ekkor

$$
0>(\ln F)^{\prime \prime}=\left(\frac{f}{F}\right)^{\prime}=\left(\frac{1}{\frac{F}{f}}\right)^{\prime}=-\frac{\left(\frac{F}{f}\right)^{\prime}}{\left(\frac{F}{f}\right)^{2}}
$$

mutatja, hogy $\frac{F}{f}$ egy szigorúan monoton növő függvény. Bebizonyítottuk tehát az alábbi állítást.

5.6. állítás. Tegyük fel, hogy egy magán értékelésü, független, azonos eloszlású harmadáras aukciónak van szigorúan monoton növô szimmetrikus optimális licitfüggvénye, és a játékosok közös eloszlása logaritmikusan konkáv. Ekkor az optimális licitfüggvény csak

$$
\beta^{I I I}(x)=x+\frac{F(x)}{(N-2) f(x)}
$$

alakú lehet. 
5.7. megjegyzés. Az eddigi feltételek mellett az alábbi nagyságrendi viszonyokat tapasztaljuk a különböző aukciók optimális licitfüggvényei közt. Minden $x$ értékelés mellett

$$
\beta^{A P}(x)=G(x) \beta^{I}(x)<\beta^{I}(x)<x=\beta^{I I}(x)<\beta^{I I I}(x) .
$$




\section{6.}

\section{KOCKÁZATSEMLEGESSÉG SÉRÜLÉSE}



MosT AZT VIZSGÁLJUK, hogy érvényben marad-e a bevételekvivalencia-elv, bizonyos feltételeinek elhagyásával.

Gondoljunk vissza az elsô- és másodáras aukciók definíciójára a 19 és a 25 oldalon. A játék (II) és (I) definíciója a játékos kockázatok iránti semlegességét fejezi ki, hiszen a hasznosság a profit lineáris függvénye. Ha $u$ valamilyen monoton növő függvény, amelyre $u(0)=0$, és a játékosok racionalitása az ottani $\Pi$ profit függvény helyett az

$$
u \circ \Pi
$$

függvény értékeinek maximalizálását jelenti, akkor a kockázat fogalma is a modellbe kerül.

6.1. definíció. Az $u:[0, \infty) \rightarrow \mathbb{R}$ függvényt Neumann-Morgenstern-féle hasznossági függvénynek mondjuk, ha az folytonos, $u(0)=0$, az értelmezési tartomány belsô pontjaiban kétszer differenciálható, $u^{\prime}(x)>0$, és $u^{\prime \prime}(x)<0$ minden $x>0$ mellett.

Amennyiben $u$ egy Neumann-Morgenstern-hasznosság, és az $i$-edik játékos az $u \circ \Pi_{i}$ függvényt optimalizálja, akkor kockázatkerülő játékosról beszélünk. A kockázatokat kerülő játékosokkal lejátszott másodáras aukció szabálya tehát

$$
\Pi_{i}= \begin{cases}u\left(x_{i}-\max _{j \neq i} b_{j}\right) & , \text { ha } b_{i}>\max _{i \neq j} b_{j} ; \\ 0 & , \text { egyébként, }\end{cases}
$$

míg az első́ras játék definíciója

$$
\Pi_{i}= \begin{cases}u\left(x_{i}-b_{i}\right) & , \text { ha } b_{i}>\max _{i \neq j} b_{j} \\ 0 & , \text { egyébként. }\end{cases}
$$

Ezt úgy is kifejezhetjük, hogy a játékosok racionalitása most nem a várt profitjuk maximalizálását jelenti, hanem a profitjuk függvényében alakuló elvárt hasznosságuk maximalizálását. Például elsőáras esetben az $x$ értékeléssel bíró játékos az optimális licitfüggvénye megtalálásához a

$$
b \mapsto G\left(\gamma^{-1}(b)\right) u(x-b)
$$

függvény maximumát keresi. Ha $u=\mathrm{id}$, akkor kapjuk a kockázatsemleges optimális licitfüggvényt.

6.2. lemma. Legyen u egy Neumann-Morgenstern-féle hasznossági függvény. Ekkor minden $x>0$ mellett

$$
\frac{u(x)}{u^{\prime}(x)}>x .
$$

Bizonyítás. Legyen $x>0$. A Lagrange-középértéktétel szerint létezik $\xi \in(0, x)$, amelyre $u(x)-u(0)=u^{\prime}(\xi) x$. No de $u^{\prime}$ szigorúan monoton fogyó, így $u^{\prime}(\xi)>u^{\prime}(x)$, ezért $u(x)>u^{\prime}(x) x$. Ezt kellett belátni. 
6.3. lemma. Legyen $\varphi:[0, \infty) \rightarrow \mathbb{R}$ folytonos, az értelmezési tartománya belsó pontjaiban differenciálható függvény, amelyre $\varphi(0)=0$. Tegyük fel, hogy amennyiben $\varphi(x) \geq 0$, úgy $\varphi^{\prime}(x)<0$. Ekkor minden $x>0$ mellett $\varphi(x)<0$.

Bizonyítás. Tegyük fel -indirekt-, hogy van $x>0$, amelyre $\varphi(x) \geq 0$. Ekkor $\varphi^{\prime}(x)<0$ szerint létezik $\delta>0$, hogy $\varphi(x-\delta)-\varphi(x)>0$. A Weierstrass-tétel szerint létezik $z \in[0, x]$, amelyre $\varphi(z)=\max \{\varphi(t): t \in[0, x]\}$. Világos, hogy $\varphi(x-\delta)>\varphi(x) \geq 0$, ezért $\varphi(0)=0$ miatt sem $z=0$, sem $z=x$ nem lehetséges. Azt kapjuk tehát, hogy $z \in(0, x)$. Ez azt jelenti, hogy $z$ a $\varphi$ lokális maximuma is, ergo $\varphi^{\prime}(z)=0$. Ez ellentmond a $\varphi(z)>\varphi(x) \geq 0$ feltételnek, hiszen ekkor $\varphi^{\prime}(z)<0$ lenne a lemma feltétele szerint. Ezt kellett belátni.

6.4. állítás. Legyen $\gamma$ egy kockázatkerülö játékosokkal lejátszott, szimmetrikus, magán értékelésú, elsốáras aukció szigorúan monoton növó, optimális licitfüggvénye. Ekkor $\gamma:[0, \omega] \rightarrow \mathbb{R}$ kielégíti az alábbi differenciálegyenletet.

$$
\gamma^{\prime}(x)=\frac{g(x)}{G(x)} \frac{u(x-\gamma(x))}{u^{\prime}(x-\gamma(x))} .
$$

Bizonyítás. Az optimalitás szerint rögzített $x$ értékeléshez adott $\gamma(x)$ az a $b$ licit, amelyre a

$$
b \mapsto G\left(\gamma^{-1}(b)\right) u(x-b)
$$

a függvény maximumán van. Ez azt jelenti, hogy a fenti függvény $b$ szerinti deriváltja éppen $\gamma(x)$-ben zérus. A $b$ szerinti derivált függvény:

$$
g\left(\gamma^{-1}(b)\right) \frac{1}{\gamma^{\prime}\left(\gamma^{-1}(b)\right)} u(x-b)-G\left(\gamma^{-1}(b)\right) u^{\prime}(x-b) .
$$

Ha $b=\gamma(x)$-et helyettesítünk, akkor a fenti kifejezés értéke zérus. Innen

$$
g(x) \frac{1}{\gamma^{\prime}(x)} u(x-\gamma(x))-G(x) u^{\prime}(x-\gamma(x))=0 .
$$

Ezt kellett belátni.

6.5. állítás. Legyen $\gamma$ egy Neumann-Morgenstern-féle kockázatkerülö játékosokkal lejátszott szimmetrikus, magán értékelésü, elsôáras aukció optimális licitfüggvénye, és $\beta$ ugyanennek az aukciónak a kockázatsemleges játékossokkal kialakuló optimális licitfüggvénye. Ekkor minden x pozitív értékelés mellett

$$
\gamma(x)>\beta(x)
$$

így a kockázatkerülö játékosok a kikiáltó számára nagyobb várható bevételt jelentenek, mint a kockázatsemleges játékosok. 
Bizonyitás. Láttuk, hogy $\gamma$ és $\beta$ rendre megoldásai a

$$
\gamma^{\prime}(x)=\frac{g(x)}{G(x)} \frac{u(x-\gamma(x))}{u^{\prime}(x-\gamma(x))} \quad \beta^{\prime}(x)=\frac{g(x)}{G(x)}(x-\beta(x))
$$

differenciálegyenleteknek. Tegyük fel, hogy valamely $x>0$ mellett $\gamma(x) \leq \beta(x)$. Ekkor a korábban igazolt $\beta(x)<x$ szerint $\gamma(x)<x$ is fennáll, tehát a Neumann-Morgensternhasznosság $u(t) / u^{\prime}(t)>t$ tulajdonsága alkalmazható $t=x-\gamma(x)>0$ mellett.

$$
\gamma^{\prime}(x)=\frac{g(x)}{G(x)} \frac{u(x-\gamma(x))}{u^{\prime}(x-\gamma(x))}>\frac{g(x)}{G(x)}(x-\gamma(x)) \geq \frac{g(x)}{G(x)}(x-\beta(x))=\beta^{\prime}(x) .
$$

A $\beta-\gamma$ függvény tehát rendelkezik avval a tulajdonsággal, hogy valahányszor $(\beta-\gamma)(x) \geq 0$ teljesül, úgy $(\beta-\gamma)^{\prime}(x)<0$ is fennáll. A 6.3 lemma szerint $\beta(x)-$ $\gamma(x)<0$ minden $x>0$ mellett. Ezt kellett belátni.

Kicsit konkrétabb példaként nézzük az $u(z)=z^{\alpha}$ függvény esetét, amikor $0<\alpha<1$. Mivel $\frac{u(z)}{u^{\prime}(z)}=\frac{z^{\alpha}}{\alpha z^{\alpha-1}}=\frac{1}{\alpha} z$ a 6.1 differenciálegyenlet most

$$
\gamma^{\prime}(x)=\frac{g(x)}{G(x)} \frac{x-\gamma(x)}{\alpha}
$$

teljesülését jelenti. Az ekvivalens avval, mintha kockázatsemleges játékosok játszanának $F$ helyett $F^{\frac{1}{\alpha}}$ eloszlásokkal. Ugyanis

$$
\frac{\left(F^{\frac{N-1}{\alpha}}\right)^{\prime}}{F^{\frac{N-1}{\alpha}}}=\frac{\frac{N-1}{\alpha} F^{\frac{N-1}{\alpha}-1} f}{F^{\frac{N-1}{\alpha}}}=\frac{1}{\alpha} \frac{(N-1) f}{F}=\frac{1}{\alpha} \frac{(N-1) F^{N-2} f}{F^{N-1}}=\frac{1}{\alpha} \frac{\left(F^{N-1}\right)^{\prime}}{F^{N-1}}=\frac{1}{\alpha} \frac{g}{G} .
$$

Igazoltuk tehát az alábbi észrevételt.

6.6. állítás. Legyen $u(z)=z^{\alpha}$, ahol $0<\alpha<1$. Tekintsük az u Neumann-Morgensternhasznossági függvénnyel rendelkezó kockázatkerülő játékosok alkotta elsôáras, magán értékelésü, szimmetrikus aukciót a közös F eloszlás függvényekkel. Ennek optimális licitfüggvénye, azonos ugyan ennek az aukciónak a kockázatsemleges játékosokkal játszott optimális licitfüggvényével, de $F^{\frac{1}{\alpha}}$ eloszlásokkal.

A kockázatkerüloo optimális licitfüggvény tehát

$$
\gamma(x)=\frac{N-1}{\alpha F^{\frac{N-1}{\alpha}}(x)} \int_{0}^{x} t f(t) F^{\frac{N-1}{\alpha}-1}(t) d t .
$$



A SZIMMETRIKUS ÉRTÉKELÉS
SÉRÜLEESE 

EBBEN A FEJEZETBEN azt vizsgáljuk, hogy hogyan változik a bevételekvivalencia-elv, amikor a játékosok értékeloszlása nem azonos. Csak a két játékos, tehát $N=2$, esetet vizsgáljuk.

A modell a következő. Elsőáras aukció két játékossal. Legyen $X_{1}, X_{2}$ nem feltétlenül azonos eloszlású, de független valószínúségi változók. Az abszolút folytonos eloszlások $F_{1}$ és $F_{2}$. A játékosok ismerik egymás eloszlásait, és ennek a ténynek az ismerete is ismert számukra. Az $X_{i}$ tartója $\left[0, \omega_{i}\right], i=1,2$, és $\omega_{2} \leq \omega_{1}$. A játékosok kockázatsemlegesek, azaz az $i$-edik játékos profitfüggvénye

$$
\Pi_{i}(b, x)=P(\{i \text { nyer }\})(x-b),
$$

ahol $x$ az értékelés és $b$ erre az értékelésre adott licit. A $\beta_{i}:\left[0, \omega_{i}\right] \rightarrow \mathbb{R}$ függvények az elsőáras optimális licitfüggvények. Feltesszük, hogy $\beta_{i}(x)<x$ minden $0<x<\omega_{i}$ mellett, és a $\beta_{i}$ függvények szigorúan monoton növő́k.

A licitfüggvények optimalitásának azonnali következménye az alábbi.

7.1. állítás. Ha $\beta_{1}, \beta_{2}$ a fenti modellben az elsóáras aukció optimális licitfüggvénye, akkor

$$
\beta_{1}(0)=\beta_{2}(0)=0, \quad \text { és } \quad \beta_{1}\left(\omega_{1}\right)=\beta_{2}\left(\omega_{2}\right)=\bar{b} .
$$

Bizonyítás. Világos, hogy $\beta_{i}(x) \leq x$ minden $x \in\left[0, \omega_{i}\right]$ mellett, hiszen az értékelés feletti licit negatív profitot eredményezhetne, ami a nulla profitnál rosszabb. Az egyensúlyi licitfüggvényre ezért csak $\beta_{i}(0)=0$ lehetséges.

Mivel a játékosok ismerik egymás eloszlásait, ezért ismerik egymás optimális licitfüggvényeit is, ezért kölcsönösen ismerik a licitfüggvények értékeit az $\omega_{1}, \omega_{2}$ végpontokban. Ha például $\beta_{2}\left(\omega_{2}\right)>\beta_{1}\left(\omega_{1}\right)$, akkor 2 játékos a maximális értékelése mellett licitjét csökkentve növeli a profitját, ami az egyensúly definíciója szerint nem lehetséges.

Láthatjuk tehát, hogy $\beta_{i}:\left[0, \omega_{i}\right] \rightarrow[0, \bar{b}]$. Érdemes itt egy pillanatra megállni és észrevenni, hogy ebből azonnal következik, hogy nem egy hatékony aukcióval állunk szemben, azaz előfordulhat, hogy az alacsonyabb értékeléssel nyeri az aukciót az 1-es játékos, mint a nála magasabb értékeléssel bíró 2-es játékos. Lásd a 7.2 ábrát. Ez egy nagyon fontos hiányossága az elsőáras aukciónak, amire még később is vissza fogunk térni.

A továbbiakban kényelmesebb a licitfüggvények inverzeivel számolni, hiszen azoknak az értelmezési tartománya azonos. Legyenek $\varphi_{1}, \varphi_{2}$ a $\beta_{1}, \beta_{2}$ függvények inverzei. Így $\varphi_{i}:[0, \bar{b}] \rightarrow\left[0, \omega_{i}\right]$. 
Jelölje

$$
H_{i}=F_{i} \circ \varphi_{i} .
$$

E függvényt az $i$ játékos liciteloszlásának nevezzük, hiszen ha $b \in[0, \bar{b}]$, akkor $H_{i}(b)=$ $P\left(X_{i}<\varphi_{i}(b)\right)=P\left(\beta_{i}\left(X_{i}\right)<b\right)$ azaz, $H_{i}(b)$ annak valószínúsége, hogy az $i$ játékos licitje $b$ alatt marad. Ha tehát $b_{i}$ az $i$ játékos licitje, akkor $H_{j}\left(b_{i}\right)$ éppen annak valószínúsége, hogy $j$ veszít, ergo $i$ nyer. Ezek szerint az $i$ játékos profitfüggvénye

$$
\Pi_{i}(b, x)=H_{j}(b)(x-b) .
$$

E függvény $b$ szerinti deriváltja $h_{j}(b)(x-b)-H_{j}(b)$. A $\beta_{i}$ egyensúlyi licitfüggvény tehát minden $x$ értékeléshez azt a $\beta_{i}(x)=b$ licitet rendeli, amely kielégíti az iménti egyenletet. Mivel $\varphi_{i}$ a $\beta_{i}$ inverze, ezért ez kifejezhető a $\varphi_{i}$ segítségével is:

$$
H_{j}(b)=h_{j}(b)\left(\varphi_{i}(b)-b\right), \quad j \neq i .
$$

Innen már egyszerúen kapjuk az alábbi állítást.

7.2. állítás. Tegyük fel, hogy $\varphi_{1}, \varphi_{2}$ az optimális licitfüggvény inverzei egy kétszemélyes elsóáras aukció esetén. Ekkor minden $0<b<\bar{b}$ mellett

1. teljesül az alábbi függvényegyenlet-rendszer

$$
\begin{aligned}
\varphi_{1}(b) & =\frac{H_{2}(b)}{h_{2}(b)}+b \\
\varphi_{2}(b) & =\frac{H_{1}(b)}{h_{1}(b)}+b ;
\end{aligned}
$$

2. és teljesül az alábbi differenciálegyenlet-rendszer

$$
\begin{aligned}
\varphi_{1}^{\prime}(b) & =\frac{F_{1}\left(\varphi_{1}(b)\right)}{f_{1}\left(\varphi_{1}(b)\right)} \frac{1}{\varphi_{2}(b)-b} \\
\varphi_{2}^{\prime}(b) & =\frac{F_{2}\left(\varphi_{2}(b)\right)}{f_{2}\left(\varphi_{2}(b)\right)} \frac{1}{\varphi_{1}(b)-b} .
\end{aligned}
$$

Bizonyítás. A (7.2) egyenletből $\varphi_{i}$-t kifejezhetjük, hiszen az inverz függvény deriválási szabálya szerint $h_{j}(b)=H_{j}^{\prime}(b)=f_{j}\left(\varphi_{j}(b)\right) \varphi_{j}^{\prime}(b) \neq 0$, ha $b \neq 0$. Így $\varphi_{i}(b)=\frac{H_{j}(b)}{h_{j}(b)}+b$, ami a függvényegyenletet igazolja.

A 7.2 egyenletbe a definíciókat visszaírva azt kapjuk, hogy $F_{j}\left(\varphi_{j}(b)\right)=$ $f_{j}\left(\varphi_{j}(b)\right) \varphi_{j}^{\prime}(b)\left(\varphi_{i}(b)-b\right)$, amiből $\varphi_{j}^{\prime}$-at kifejezve kapjuk, hogy

$$
\varphi_{j}^{\prime}(b)=\frac{F_{j}\left(\varphi_{j}(b)\right)}{f_{j}\left(\varphi_{j}(b)\right)} \frac{1}{\varphi_{i}(b)-b},
$$

ami éppen a kívánt differenciálegyenlet. 


\subsection{Egyenletes eloszlások esete}

Az előző állítás illusztrációjaként nagyon érdekes részletesen is kiszámolni azt az esetet, amikor az 1 játékos értékelése a $\left[0, \omega_{1}\right]$ intervallumon egyenletes eloszlású, és a 2 játékos értékelése a $\left[0, \omega_{2}\right]$ intervallum mint tartó felett egyenletes eloszlású. Most is tegyük fel, hogy $\omega_{2}<\omega_{1}$. Ekkor persze

$$
\begin{array}{ll}
F_{1}(x)=\frac{1}{\omega_{1}} x & f_{1}=\frac{1}{\omega_{1}} ; \\
F_{2}(x)=\frac{1}{\omega_{2}} x & f_{2}=\frac{1}{\omega_{2}} .
\end{array}
$$

Világos, hogy $F_{1}(x)<F_{2}(x)$ minden $x \in\left(0, \omega_{2}\right)$ mellett, tehát 1 eloszlása sztochasztikusan dominálja 2 eloszlását. Célunk, hogy a 7.5 differenciálegyenlet-rendszer alapján meghatározzuk az optimális licitfüggvények inverzét, majd az optimális licitfüggvényeket.

Írjuk fel először a 7.5 speciális esetét. Minden $0<b<\bar{b}$ mellett

$$
\varphi_{j}^{\prime}(b)=\frac{F_{j}\left(\varphi_{j}(b)\right)}{f_{j}\left(\varphi_{j}(b)\right)} \frac{1}{\varphi_{i}(b)-b}=\frac{\frac{1}{\omega_{j}} \varphi_{j}(b)}{\frac{1}{\omega_{j}}} \frac{1}{\varphi_{i}(b)-b}=\frac{\varphi_{j}(b)}{\varphi_{i}(b)-b} .
$$

Azt kaptuk tehát, hogy amennyiben a modell feltételeinek megfelelő licitfüggvények léteznek, úgy az inverzük kielégíti a

$$
\begin{aligned}
\varphi_{1}^{\prime}(b) & =\frac{\varphi_{1}(b)}{\varphi_{2}(b)-b}, \\
\varphi_{2}^{\prime}(b) & =\frac{\varphi_{2}(b)}{\varphi_{1}(b)-b}
\end{aligned}
$$

differenciálegyenlet-rendszert.

Most megmutatjuk, hogy ez a differenciálegyenlet-rendszer visszavezethetô egy szétválasztható változójú differenciálegyenletre. A trükk, hogy $\left(\varphi_{1}(b)-b\right)\left(\varphi_{2}(b)-b\right)$ deriváltját keressük. Adjunk -1 -et (7.5) mindkét egyenletéhez, majd szorozzunk fel a jobboldali nevezővel. Így

$$
\begin{aligned}
\left(\varphi_{1}^{\prime}(b)-1\right)\left(\varphi_{2}(b)-b\right) & =\varphi_{1}(b)-\varphi_{2}(b)+b, \\
\left(\varphi_{2}^{\prime}(b)-1\right)\left(\varphi_{1}(b)-b\right) & =\varphi_{2}(b)-\varphi_{1}(b)+b .
\end{aligned}
$$

Ha észrevesszük, hogy $\left(\varphi_{1}^{\prime}(b)-1\right)=\left(\varphi_{1}(b)-b\right)^{\prime}$, akkor a fenti egyenletek összeadásával azt kapjuk, hogy

$$
\left(\left(\varphi_{1}(b)-b\right)\left(\varphi_{2}(b)-b\right)\right)^{\prime}=\left(\varphi_{1}^{\prime}(b)-1\right)\left(\varphi_{2}(b)-b\right)+\left(\varphi_{2}^{\prime}(b)-1\right)\left(\varphi_{1}(b)-b\right)=2 b .
$$


Figyelembe véve, hogy $\varphi_{i}(0)=0$,

$$
\left(\varphi_{1}(b)-b\right)\left(\varphi_{2}(b)-b\right)=b^{2} .
$$

Ebből két dolog látszik azonnal. Egyrészt megkapjuk $\bar{b}$ értékét, hiszen a fenti egyenletbe $\bar{b}$ helyettesítve, $\left(\omega_{1}-\bar{b}\right)\left(\omega_{2}-\bar{b}\right)=\bar{b}^{2}$, azaz

$$
\bar{b}=\frac{\omega_{1} \omega_{2}}{\omega_{1}+\omega_{2}} .
$$

Másrészt a (7.5) rendszer egyetlen egyenletre egyszerúsödik, hiszen $\varphi_{j}(b)-b=$ $\frac{b^{2}}{\varphi_{i}(b)-b}$. A 7.5 rendszer mindkét egyenlete tehát a

$$
\varphi^{\prime}(b)=\frac{\varphi(b)(\varphi(b)-b)}{b^{2}}
$$

szétválasztható változójú differenciálegyenletre egyszerúsödik, ahol minden $b>0$ mellett $\varphi(b)>b$.

7.3. lemma. A (7.6) differenciálegyenlet általános megoldása a következó:

$$
\varphi(b)=\frac{2 b}{1+c b^{2}} .
$$

Bizonyítás. Keressük a megoldást $\varphi(b)-b=\xi(b) b$ alakban. Ekkor $\varphi(b)=b(1+$ $\xi(b))$ és $\varphi^{\prime}(b)=1+\xi(b)+b \xi^{\prime}(b)$. Tehát a 7.6 egyenlet így az

$$
\begin{aligned}
1+\xi(b)+b \xi^{\prime}(b) & =\frac{1}{b^{2}} b(1+\xi(b)) \xi(b) b \\
1+\xi(b)+b \xi^{\prime}(b) & =\xi(b)+\xi^{2}(b) \\
\xi^{\prime}(b) & =\frac{\xi^{2}(b)-1}{b}, \quad \xi(b)>0
\end{aligned}
$$

egyenletbe megy át, ahol $\varphi(b)>b$ miatt minden $b>0$ mellett $\xi(b)=\frac{\varphi(b)}{b}-1>0$.

A (7.7) differenciálegyenletet kell tehát megoldanunk. Világos, hogy a konstans $\xi(b)=1$ egy megoldás. Egyébként az egyenlet

$$
\frac{1}{x^{2}-1} \cdot x^{\prime}=\frac{1}{b}
$$

alakú. Parciális törtekre bontással $\frac{1}{x^{2}-1}=\frac{1}{2}\left(\frac{1}{x-1}-\frac{1}{x+1}\right)$. Az antideriváltra tehát

$$
\int \frac{1}{x^{2}-1}= \begin{cases}\ln \sqrt{\frac{x-1}{x+1}}, & \text { ha } x>1 \\ \ln \sqrt{\frac{1-x}{x+1}}, & \text { ha } 0<x<1 .\end{cases}
$$




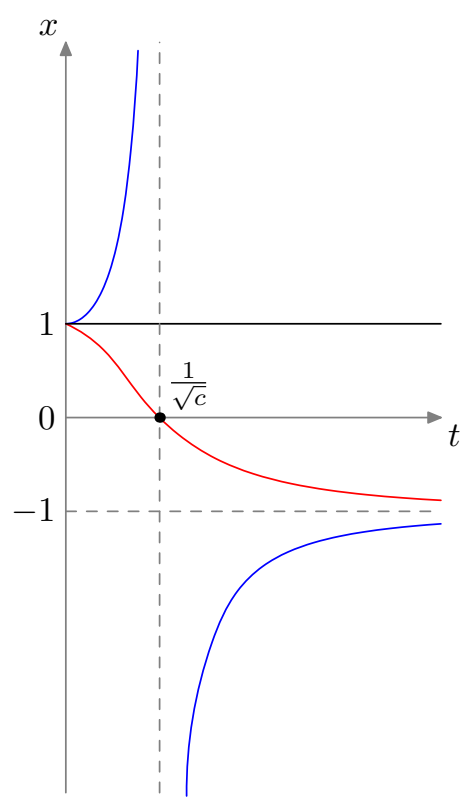

7.1. ábra. A 7.7 szétválasztható változójú differenciálegyenlet megoldásai

Ha $x(b)>1$, akkor az $x$ függvényre

$$
\begin{aligned}
\left(\int \frac{1}{x^{2}-1} d x\right)^{\prime} & =\frac{1}{b} \\
\ln \left(\sqrt{\frac{x-1}{x+1}}\right) & =c+\ln b \\
\sqrt{\frac{x-1}{x+1}} & =c b \\
\frac{x-1}{x+1} & =c b^{2} \\
x-1 & =c b^{2} x+c b^{2} \\
x\left(1-c b^{2}\right) & =1+c b^{2} \\
x(b) & =\frac{1+c b^{2}}{1-c b^{2}},
\end{aligned}
$$

valamely $c>0$ konstans mellett.
Analóg módon $0<x(b)<1$ mellett

$$
\begin{aligned}
\left(\int \frac{1}{x^{2}-1} d x\right)^{\prime} & =\frac{1}{b} \\
\ln \left(\sqrt{\frac{1-x}{x+1}}\right) & =c+\ln b \\
\sqrt{\frac{1-x}{x+1}} & =c b \\
\frac{1-x}{x+1} & =c b^{2} \\
1-x & =c b^{2} x+c b^{2} \\
x\left(1+c b^{2}\right) & =1-c b^{2} \\
x(b) & =\frac{1-c b^{2}}{1+c b^{2}},
\end{aligned}
$$

valamilyen $c>0$ mellett. 
Visszatérve (7.7) megoldására azt kaptuk, hogy a megoldás mindenképpen

$$
\xi^{\prime}(b)=\frac{1-c b^{2}}{1+c b^{2}}
$$

alakú. Ha $c=0$, akkor ez a konstans 1 függvény; ha $c<0$, akkor $\xi(b)>1$; ha $c>0$ akkor $\xi(b)<1$. Lásd a 7.1 ábrát. Innen

$$
\varphi(b)=b(1+\xi(b))=b\left(1+\frac{1-c b^{2}}{1+c b^{2}}\right)=\frac{2 b}{1+c b^{2}} .
$$

Ezt kellett belátni.

Azt mutattuk meg az eddigiekben, hogy a 7.5 rendszer megoldása

$$
\begin{aligned}
\varphi_{1}(b) & =\frac{2 b}{1+k_{1} b^{2}} \\
\varphi_{2}(b) & =\frac{2 b}{1+k_{2} b^{2}} .
\end{aligned}
$$

Most meghatározzuk a fenti $k_{1}$ és $k_{2}$ konstansokat. A (7.9) speciális eseteként $\omega_{1}=$ $\frac{2 \bar{b}}{1+k_{1} \bar{b}^{2}}$ és $\omega_{2}=\frac{2 \bar{b}}{1+k_{2} \bar{b}^{2}}$. Persze emlékszünk, hogy $\bar{b}=\frac{\omega_{1} \omega_{2}}{\omega_{1}+\omega_{2}}$. Így

$$
\omega_{1}=\frac{2 \frac{\omega_{1} \omega_{2}}{\omega_{1}+\omega_{2}}}{1+k_{1}\left(\frac{\omega_{1} \omega_{2}}{\omega_{1}+\omega_{2}}\right)^{2}}=\frac{2 \omega_{1} \omega_{2}}{\omega_{1}+\omega_{2}+k_{1} \frac{\left(\omega_{1} \omega_{2}\right)^{2}}{\omega_{1}+\omega_{2}}} .
$$

Innen $\omega_{1}$ és $\omega_{2}$-vel való egyszerúsítés után azt kapjuk, hogy $\omega_{1}+k_{1} \frac{\omega_{1}^{2} \omega_{2}^{2}}{\omega_{1}+\omega_{2}}=\omega_{2}$, ahonnan

$$
k_{1}=\frac{\omega_{2}^{2}-\omega_{1}^{2}}{\omega_{2}^{2} \omega_{1}^{2}}=\frac{1}{\omega_{1}^{2}}-\frac{1}{\omega_{2}^{2}} .
$$

A fentivel analóg számolgatás mutatja, hogy

$$
k_{2}=\frac{1}{\omega_{2}^{2}}-\frac{1}{\omega_{1}^{2}} .
$$

Világos, hogy $\omega_{2} \leq \omega_{1}$ miatt $k_{1} \leq 0, k_{2} \geq 0$ és $k_{2}=-k_{1}$. Könnyen látszik, hogy $\bar{b}=$ $\frac{\omega_{1} \omega_{2}}{\omega_{1}+\omega_{2}}<\frac{\omega_{1} \omega_{2}}{\sqrt{\omega_{1}^{2}-\omega_{2}^{2}}}=\frac{1}{\sqrt{k_{2}}}$, ami azt jelenti, hogy $\varphi_{1}(b)$ nevezője valóban pozitív. Ebből már nyilvánvalóan következik, hogy minden $0<b<\bar{b} \varphi_{1}(b)>\varphi_{2}(b)$, azaz minden $0<x<\omega_{2}$ mellett $\beta_{1}(x)<\beta_{2}(x)$. 


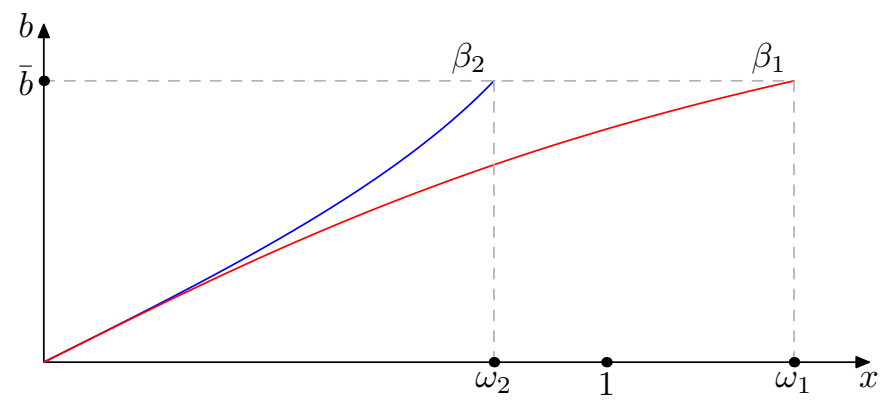

7.2. ábra. A licitfüggvények grafikonja, amikor $\omega_{1}=\frac{4}{3}$ és $\omega_{2}=\frac{4}{5}$.

\subsection{Első- és másodáras bevételek összehasonlítása}

Alkalmazzuk az előző pont eredményeit, mikor valamely $\alpha \in[0,1)$ mellett

$$
\omega_{2}=\frac{1}{1+\alpha}, \omega_{1}=\frac{1}{1-\alpha} .
$$

Először írjuk fel az elsőáras aukció bevételének eloszlását. Világos, hogy

$$
F_{1}(x)=(1-\alpha) x, F_{2}(x)=(1+\alpha) x \text {, és } \bar{b}=\frac{\omega_{1} \omega_{2}}{\omega_{1}+\omega_{2}}=\frac{\frac{1}{1-\alpha^{2}}}{\frac{1-\alpha+1+\alpha}{1-\alpha^{2}}}=\frac{1}{2} \text {. }
$$

A megoldásokhoz $\frac{1}{\omega_{1}^{2}}-\frac{1}{\omega_{2}^{2}}=(1-\alpha)^{2}-(1+\alpha)^{2}=-4 \alpha$.

Így tehát $\varphi_{1}, \varphi_{2}:[0,1 / 2] \rightarrow \mathbb{R}$

$$
\varphi_{1}(b)=\frac{2 b}{1-4 \alpha b^{2}} \quad \text { és } \quad \varphi_{2}(b)=\frac{2 b}{1+4 \alpha b^{2}} .
$$

A fenti függvények $\beta_{1}, \beta_{2}$ inverzeinek mérethelyes grafikonját tartalmazza a 7.2 ábra, abban a speciális esetben, amikor az $\alpha=\frac{1}{4}$ paramétert állítjuk be.

A kikiáltó bevételének eloszlására tetszőleges $0<p<\frac{1}{2}$ esetén

$$
\begin{aligned}
& L_{\alpha}^{1}(p)=P\left(\max \left\{\beta_{1}\left(X_{1}\right), \beta_{2}\left(X_{2}\right)\right\}<p\right)= \\
& P\left(\beta_{1}\left(X_{1}\right)<p\right) P\left(\beta_{2}\left(X_{2}\right)<p\right)=F_{1}\left(\varphi_{1}(p)\right) F_{2}\left(\varphi_{2}(p)\right)= \\
& (1-\alpha) \frac{2 p}{1-4 \alpha p^{2}}(1+\alpha) \frac{2 p}{1+4 \alpha p^{2}}=\frac{\left(\alpha^{2}-1\right) c}{\alpha^{2} c^{2}-1}
\end{aligned}
$$

ahol $c=(2 p)^{2}$. E tört $\alpha$ szerinti deriváltjának számlálója $2 \alpha c\left(c^{2}-1\right)<0$. Ez azt jelenti, hogy minden rögzített $0<p<\frac{1}{2}$ mellett $L_{0}^{1}(p)>L_{\alpha}^{1}(p)$, azaz $L_{\alpha}^{1}$ sztochasztikusan 
dominálja $L_{0}^{1}$-et minden $\alpha \in(0,1)$ mellett, ergo

$$
E\left(L_{\alpha}^{1}\right)>E\left(L_{0}^{1}\right)
$$

Most írjuk fel a másodáras szigorúan monoton nővő egyensúlyi bevétel-eloszlást. Ez sokkal egyszerúbb, hiszen aszimmetrikus esetben is az identitás függvény lehet csak az optimális, a szigorúan monoton növekedő feltétel miatt. Így minden $p \in\left(0, \omega_{2}\right)$ mellett

$$
\begin{aligned}
& L_{\alpha}^{2}(p)=P\left(\min \left\{X_{1}, X_{2}\right\} \leq p\right)= \\
& \quad P\left(\left(X_{1} \leq p\right) \cup\left(X_{2} \leq p\right)\right)=F_{1}(p)+F_{2}(p)-F_{1}(p) F_{2}(p)= \\
& \quad(1-\alpha) p+(1+\alpha) p-(1-\alpha)(1+\alpha) p^{2}=2 p+\left(\alpha^{2}-1\right) p^{2} .
\end{aligned}
$$

Világos, hogy $[0,1)$ felett e függvény mint $\alpha$ függvénye szigorúan monoton nô, tehát tetszőlegesen rögzített $\alpha \in(0,1)$ esetén

$$
L_{0}^{2}(p)<L_{\alpha}^{2}(p)
$$

minden $p \in\left(0, \omega_{2}\right)$ mellett, azaz $L_{0}^{2}$ sztochasztikusan dominálja $L_{\alpha}^{2}$-t, ergo

$$
E\left(L_{\alpha}^{2}\right)<E\left(L_{0}^{2}\right)
$$

Persze az $\alpha=0$ esetben a két licitáló eloszlása a $[0,1]$-en egyenletes, ami a bevételekvivalencia-elv esete, tehát a kikiáltó várható bevétele ugyanaz mind az elsőáras, mind a másodáras esetben.

Így $\alpha>0$ esetében

$$
E\left(L_{\alpha}^{2}\right)<E\left(L_{0}^{2}\right)=E\left(L_{0}^{1}\right)<E\left(L_{\alpha}^{1}\right)
$$

Láttuk tehát, hogy az aszimmetrikus licitálók esetében a bevételekvivalencia-elv következménye nem marad igaz: a kikiáltó várható árbevétele más és más elsó- és másodáras esetben. 
8.

ERŐSZAKOS LICITÁLÓ 

AZ ELŐZŐ FEJEZET példájában, ha $\omega_{2}<\omega_{1}$, akkor az $X_{1}$ játékos sztochasztikusan dominálja az $X_{2}$ játékost:

$$
F_{1}(x)=\frac{1}{\omega_{1}} x<\frac{1}{\omega_{2}} x=F_{2}(x) .
$$

Láttuk, hogy $X_{2}$ minden értékeléshez nagyobb licitet ad, mint $X_{1}$ ugyanezen értékeléshez. Most ezt az állítást próbáljuk általánosítani sztochasztikus dominanciában álló eloszlások mellett, de ehhez erôsebb dominancia fogalomra van szükségünk:

8.1. definíció (sztochasztikus dominancia a fordított kockázati ráta értelmében). Legyen $X_{1}$ eloszlása és sûrúségfüggvénye $F_{1}$ illetve $f_{1}$, tartója $\left[0, \omega_{1}\right]$. Hasonlóan $X_{2}$ eloszlása és sûrûségfüggvénye $F_{2}, f_{2}$ a $\left[0, \omega_{2}\right]$ tartóval. Tegyük fel, hogy $\omega_{2} \leq \omega_{1}$. Azt mondjuk, hogy $X_{1}$ sztochasztikusan dominálja $X_{2}$-t a fordított kockázati ráta értelmében, ha

$$
\frac{F_{1}}{f_{1}}<\frac{F_{2}}{f_{2}}
$$

a $\left(0, \omega_{2}\right)$ minden pontja felett.

A szokásos simasági feltevéseink mellett ez avval ekvivalens, hogy az $\frac{F_{1}}{F_{2}}$ függvény szigorúan monoton nő a $\left[0, \omega_{2}\right]$ intervallumon:

$$
\frac{F_{1}}{f_{1}}<\frac{F_{2}}{f_{2}} \Longleftrightarrow F_{1}^{\prime} F_{2}-F_{2}^{\prime} F_{1}>0 \Longleftrightarrow\left(\frac{F_{1}}{F_{2}}\right)^{\prime}>0 .
$$

Ekkor persze minden $x<\omega_{2}$ esetén $\frac{F_{1}(x)}{F_{2}(x)}<F_{1}\left(\omega_{2}\right) \leq 1$, ami azt jelenti $F_{1}(x)<F_{2}(x)$ is fennáll, ergo a most bevezetett sztochasztikus dominancia erősebb, mint a szokásos sztochasztikus dominancia fogalma. Hogy nem ekvivalens a két dominancia koncepció, az abból is látszik, hogy ha $\omega_{2}<\omega_{1}$, akkor a $\left[0, \omega_{2}\right]$ és a $\left[0, \omega_{1}\right]$ feletti egyenletes eloszlásokkal

$$
F_{1}(x)=\frac{1}{\omega_{1}} x<\frac{1}{\omega_{2}} x=F_{2}(x) \text {, ám } \frac{F_{1}}{F_{2}}(x)=\frac{\omega_{2}}{\omega_{1}} .
$$

8.2. lemma. Legyen $\varphi:[0, \omega] \rightarrow \mathbb{R}$ függvény, amely folytonos és az értelmezési tartománya belsejében differenciálható. Tegyük fel, hogy $\varphi$ rendelkezik az alábbi tulajdonsággal:

$$
\forall x \in(0, \omega), \varphi(x)=0 \Longrightarrow \varphi^{\prime}(x)>0 .
$$

Ekkor a $\varphi$ függvénynek legfeljebb egy zérus helye van az értelmezési tartománya belsejében.

Bizonyítás. Ha $x \in(0, \omega)$ egy zérushely, akkor $\varphi^{\prime}(x)>0$ miatt van olyan $h>0$ szám, melyre minden $x<x^{\prime}<x+h$ esetén $0<f\left(x^{\prime}\right)$ és minden $x-h<x^{\prime}<x$ esetén $f\left(x^{\prime}\right)<0$. Ebből két dolgot következtetünk. Egyrészt a Bolzano-tétel miatt az értelmezési tartomány bármely két belső pontbeli gyöke közt van egy harmadik gyök is, 
másrészt minden gyöknek van olyan nyílt környezete, melyben csak egyetlen gyök van. Na most, ha lenne két $a, b$ gyök az értelmezési tartományon belül, akkor az

$$
\{x: x \in[a, b], \varphi(x)=0\}
$$

halmaz kompakt lenne, így a fenti lefedéséből is kiválasztható véges lefedés. Mivel minden lefedő nyílt halmazban egyetlen gyök van, ezért a fenti halmaz véges. Másrészt, ha bármely két gyök közt van harmadik gyök, akkor bármely két gyök közt van végtelen sok gyök is, így a fenti halmaz nem véges.

Minden kész, hogy megfogalmazhassuk a sejtésből eredő állítást.

8.3. állítás (Gyengeség erőszakos licitáláshoz vezet). A kétszemélyes aszimmetrikus modellben, ha $X_{1}$ sztochasztikusan dominálja $X_{2}$-t a fordított kockázati ráta értelmében, akkor a szigorúan monoton növő Nash-egyensúlyi licitfüggvényekre minden $x \in\left(0, \omega_{2}\right)$ mellett

$$
\beta_{1}(x)<\beta_{2}(x)
$$

Bizonyítás. Jelölje $\varphi=\beta_{1}-\beta_{2}$. Tegyük fel, hogy valamely $0<x<\omega_{2}$ mellett $\beta_{1}(x)=$ $\beta_{2}(x)=b$. Persze $b<\bar{b}$ és $\varphi_{1}(b)=\varphi_{2}(b)=x$. Emiatt $(7.5)$-t figyelembe véve

$$
\begin{aligned}
& \frac{1}{\beta_{2}^{\prime}(x)}=\varphi_{2}^{\prime}(b)= \\
& \frac{F_{2}\left(\varphi_{2}(b)\right)}{f_{2}\left(\varphi_{2}(b)\right)} \frac{1}{\varphi_{1}(b)-b}=\frac{F_{2}(x)}{f_{2}(x)} \frac{1}{x-b}>\frac{F_{1}(x)}{f_{1}(x)} \frac{1}{x-b}=\frac{F_{1}\left(\varphi_{1}(b)\right)}{f_{1}\left(\varphi_{1}(b)\right)} \frac{1}{\varphi_{2}(b)-b}= \\
& \varphi_{1}^{\prime}(b)=\frac{1}{\beta_{1}^{\prime}(x)} .
\end{aligned}
$$

Eddig tehát azt látjuk, hogy ha $\varphi(x)=\beta_{1}(x)-\beta_{2}(x)=0$, akkor $\varphi^{\prime}(x)=\beta_{1}^{\prime}(x)-$ $\beta_{2}^{\prime}(x)>0$ is teljesül. A $\varphi$ függvénynek tehát legfeljebb egy gyöke van a $\left(0, \omega_{2}\right)$ intervallumban. Az alábbi esetek lehetségesek tehát:

1. $\varphi(x)>0, \forall x \in\left(0, \omega_{2}\right)$;

2. $\varphi(x)<0, \forall x \in\left(0, \omega_{2}\right)$;

3. $\exists \bar{x}<\omega_{2}$, amelyre $\varphi(x)>0 \forall x \in\left(\bar{x}, \omega_{2}\right)$.

Világos, hogy éppen a középső $\varphi<0$-t kell belátnunk.

Innen tegyük fel indirekt, hogy a felsorolás elsố vagy harmadik pontja teljesül. Ekkor persze a harmadik pont is fennáll, ergo valamely $\bar{x}<\omega_{2}$ mellett tetszőlleges $\bar{x}<x<\omega_{2}$ 
esetén $\varphi(x)=\beta_{1}(x)-\beta_{2}(x)>01^{1}$ Az inverz függvényekre áttérve ez azt jelenti, hogy létezik $\delta>0$, hogy minden $\bar{b}-\delta<b<\bar{b}$ esetén $\varphi_{1}(b)<\varphi_{2}(b)$. Emiatt

$$
H_{1}(b)=F_{1}\left(\varphi_{1}(b)\right)<F_{1}\left(\varphi_{2}(b)\right)<F_{2}\left(\varphi_{2}(b)\right)=H_{2}(b)
$$

minden $b \in(\bar{b}-\delta, \bar{b})$ esetén. Alkalmazva a Cauchy-középértéktételt egy $[b, \bar{b}]$ intervallumon azt kapjuk, hogy létezik $\bar{b}-\delta<b<b^{\prime}<\bar{b}$, hogy

$$
1 \geq \frac{1-H_{2}(b)}{1-H_{1}(b)}=\frac{H_{2}(\bar{b})-H_{2}(b)}{H_{1}(\bar{b})-H_{1}(b)}=\frac{h_{2}\left(b^{\prime}\right)}{h_{1}\left(b^{\prime}\right)} \Longrightarrow h_{2}\left(b^{\prime}\right) \leq h_{1}\left(b^{\prime}\right),
$$

amiből már a számlálót és a nevezôt is becsülhetjük a $b^{\prime}$ pontban, figyelembe véve 7.3-at:

$$
\varphi_{1}\left(b^{\prime}\right)=\frac{H_{2}\left(b^{\prime}\right)}{h_{2}\left(b^{\prime}\right)}+b^{\prime}>\frac{H_{1}\left(b^{\prime}\right)}{h_{1}\left(b^{\prime}\right)}+b^{\prime}=\varphi_{2}\left(b^{\prime}\right),
$$

ami ellentmondás.

Végül is azt mutattuk meg, hogy ha az egyik játékos értékelésének eloszlása a fordított kockázati ráta értelmében sztochasztikusan dominálja a másik játékos eloszlását, akkor ez a dominancia öröklődik az egyensúlyi licitekkel képzett licit-eloszlásokra is. Ugyanis a fenti tétel feltételei mellett

$$
\frac{F_{1}}{f_{1}}<\frac{F_{2}}{f_{2}} \Longrightarrow \beta_{1}<\beta_{2} \Longleftrightarrow \varphi_{2}<\varphi_{1} \Longleftrightarrow \frac{H_{1}}{h_{1}}<\frac{H_{2}}{h_{2}}
$$

${ }^{1}$ Nem szükséges visszatérni az inverz függvényekhez, ha az erősebb $\omega_{2}<\omega_{1}$ feltevéssel élünk. Ugyanis ekkor $\beta_{1}\left(\omega_{2}\right)<\beta_{1}\left(\omega_{1}\right)=\beta_{2}\left(\omega_{2}\right)$, ami nem lehetséges a függvények folytonossága miatt. 



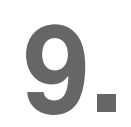

AUKCIÓ MINT MECHANIZMUS 

LÁTTUK, HOGY A játékosok különböző eloszlásait megengedve a bevételekvivalenciaelv sérül. A hátralévő fejezetekben azt a kérdést vizsgáljuk, hogy a bevételekvivalenciaelvből mennyit és hogyan lehet megmenteni a szimmetrikus esetről az aszimmetrikus esetre való áttérés mellett, tehát amikor az egyes licitálók más és más értékeloszlással rendelkeznek.

A mechanizmus szerkesztéssel kapcsolatos fejezeteteket avval kezdjük, hogy definiálunk egy olyan struktúrát, amely az eddigi aukció fogalmunkat általánosítja.

A jelen fejezet legfontosabb része a revelációs elv, amely arra szolgál, hogy az eddigiek talán legfontosabb függvényét, a licitfüggvényt kivegyük a modellből. Ez először meghökkentő, de egyben természetes gondolat is, hiszen ha egy kialakult Nashegyensúlyra tekintünk, azaz ha ismerjük az egyes játékosok szigorúan monoton növő licitfüggvényeit, akkor a licitekből az értékelés visszaszámolható, azaz mindegy, hogy a játékosok az értékelésüket közlik az aukció lejátszásakor, vagy az értékelésük által egyértelmúen meghatározott licitjüket. Mindkét esetben a játékosok végül is felfedik a valódi értékelésüket. Ebben az értelemben minden Nash-egyensúlyi helyzetben lejátszott aukció tekinthető olyan mechanizmusnak - ez a direkt-mechanizmus -, ahol minden játékos igazmondó, azaz a valódi értékelését fedi fel.

\subsection{A modell}

Az egész fejezetben az alábbi modellt vizsgáljuk. Legyen $N$ a játékosok száma. Jelölje $F_{1}, \ldots, F_{N}$ az értékelések abszolút folytonos eloszlásait a $\left[0, \omega_{i}\right]$ tartókon. Az eddigi szokásoknak megfelelően $f_{1}, \ldots, f_{N}$ a súrúségfüggvények. Jelölje $\Xi=\times_{i=1}^{N}\left[0, \omega_{i}\right] \subset$ $\mathbb{R}^{N}$ és $\Xi_{-i}=\times_{j \neq i}\left[0, \omega_{j}\right] \subset \mathbb{R}^{N-1}$. Tegyük fel, hogy az értékelések függetlenek. Jelölje $f: \Xi \rightarrow \mathbb{R}$

$$
f(x)=\prod_{i=1}^{N} f_{i}\left(x_{i}\right)
$$

az együttes sûrúségfüggvényt, ahol $x=\left(x_{1}, \ldots, x_{N}\right)$. Hasonlóan $f_{-i}: \Xi_{-i} \rightarrow \mathbb{R}$ az $i$-tôl különböző játékosok együttes sûrúsége, tehát $x_{-i} \in \Xi_{-i}$ mellett

$$
f_{-i}\left(x_{-i}\right)=\prod_{j \neq i} f_{j}\left(x_{j}\right)
$$

$\mathrm{A} \psi_{i}:\left[0, \omega_{i}\right] \rightarrow \mathbb{R}$ függvény

$$
\psi_{i}(x)=x-\frac{1-F_{i}(x)}{f_{i}(x)}
$$

az $i$ játékos virtuális értékelése. 


\subsection{Mechanizmus}

Valamely konkrét aukció forma meghatározása két dolgot jelent. Definiálnunk kell tetszőleges licit helyzetben, hogy ki az aukció nyertese, azaz hogy kié az árverés tárgya és, hogy ez kinek mekkora fizetési kötelezettséget jelent.

9.1. definíció (Mechanizmus). Mechanizmusnak nevezünk egy $(\mathscr{B}, \pi, \mu)$ hármast, ahol

1. $\mathscr{B} \subset \mathbb{R}^{N}$ egy tetszőlegesen választott, de a továbbiakban rögzített halmaz, amelyet szignál halmaznak nevezünk;

2. $\pi: \mathscr{B} \rightarrow \mathbb{R}^{N}$ az allokáció függvény, melynek $\pi=\left(\pi_{1}, \ldots, \pi_{N}\right)$ koordináta függvényeire minden $x \in \mathscr{B}, x=\left(x_{1}, \ldots, x_{N}\right)$ szignál vektor esetén $0 \leq \pi_{i}(x) \leq 1$ és $\sum_{i=1}^{N} \pi_{i}(x) \leq 1$.

3. $\mu: \mathscr{B} \rightarrow \mathbb{R}^{N}$ a befizetési függvény, melynek $\mu=\left(\mu_{1}, \ldots, \mu_{N}\right)$ koordináta függvényei a $\mu_{i}: \mathscr{B} \rightarrow \mathbb{R}$ függvények.

Egy $b \in \mathscr{B}$ szignál vektor mellett a $(\pi(b), \mu(b))$ párt a mechanizmus egy kimenetének mondjuk.

A fenti struktúrához rendelt intuíció valamely aukcióval kapcsolatban a következő.

1. A $\mathscr{B}$ szignálhalmaz az aukció résztvevői által leadható összes licitvektorok halmaza. $b \in \mathscr{B}$ jelentése tehát a $b=\left(b_{1}, \ldots, b_{N}\right)$ jelölés mellett, hogy $b_{i}$ az $i$-edik játékos által leadott licit, azaz jel az ő értékeléséről.

2. A $\pi: \mathscr{B} \rightarrow \mathbb{R}^{N}$ allokáció függvény $i$-edik $\pi_{i}$ koordináta függvénye azt fejezi ki, hogy a $b$ szignál vektor esetén $\pi_{i}(b)$ az $i$ játékos nyerésének valószínúsége. Feltúnô, hogy csak $\sum_{i=1}^{N} \pi_{i}(b) \leq 1$-et követelünk meg. Ennek oka, hogy nem akarjuk kizárni azon licitvektorokat, amelyek nem eredményeznek nyertest. Gondoljunk például egy rezervációs ár mellett lejátszott aukcióra. Ha egyetlen játékos licitje sem éri el a rezervációs árat, akkor az aukció lejátszásának szabályai szerint a tárgy a kikiáltónál marad, tehát nincs nyertes.

Ha az aukció szabályai olyanok, hogy minden olyan $b \in \mathscr{B}$ szignál esetén, amikor van az aukciónak nyertese a nyertes személye egyértelmúen meghatározott, akkor a $\pi_{i}(b), i=1, \cdots, N$ számok közül egyetlen egynek az értéke 1 , a többi pedig 0 . Viszont, ha figyelembe vesszük, hogy azonos licitek is lehetségesek, akkor nehéz ilyen szabályozást elképzelni. Emiatt valószínúségek a $\pi_{i}(b)$ számok. Például, ha az a lejátszás szabálya, hogy az azonos licittel rendelkezó nyertesek közt valamilyen szétlövést rendeznek, akkor $\pi_{i}(b)=0$ minden nem nyertes $i$ licitálóra, és $\pi_{i}(b) \leq 1$ minden nyertes $i$ licitálóra olyan módon, hogy a nyertes licitálókra összegezve a $\pi_{i}(b)$ számokat az összeg 1 legyen.

3. A $\mu: \mathscr{B} \rightarrow \mathbb{R}^{N}$ függvény $i$-edik koordináta függvénye egy $b \in \mathscr{B}$ szignál rendszer mellett az $i$ játékos $\mu_{i}(b)$ fizetési kötelezettségét jelenti. Avval, hogy a játékos 
részt vesz az aukción, azt fogadja el, hogy teljesíteni fogja a $\mu_{i}$ befizetési szabály által előírt kötelezettségét.

Példaként érdemes felírni az eddigi konkrét aukciókat mint mechanizmusokat.

Elsố áras: Egy $b=\left(b_{1}, \ldots, b_{N}\right)$ licit vektor mellett

$$
\begin{aligned}
& \pi_{i}(b)= \begin{cases}1 & , \text { ha } b_{i}>\max \left\{b_{j}: j \neq i\right\} ; \\
0 & , \text { egyébként, }\end{cases} \\
& \mu_{i}(b)=\pi_{i}(b) \cdot \max \left\{b_{j}: j=1, \ldots, N\right\} .
\end{aligned}
$$

Elsố áras $r$ rezervációs árral: Egy $b=\left(b_{1}, \ldots, b_{N}\right)$ licit vektor mellett

$$
\begin{aligned}
& \pi_{i}(b)= \begin{cases}1 & , \text { ha } b_{i}>b_{j} \forall j \neq i \text { és } b_{i} \geq r ; \\
0 & , \text { egyébként, }\end{cases} \\
& \mu_{i}(b)=\pi_{i}(b) \cdot \max \left\{b_{j}, r: j=1, . ., N\right\} .
\end{aligned}
$$

Másod áras: Egy $b=\left(b_{1}, \ldots, b_{N}\right)$ licit vektor mellett

$$
\begin{aligned}
& \pi_{i}(b)= \begin{cases}1 & , \text { ha } b_{i}>b_{j} \forall j \neq i \\
0 & , \text { egyébként, }\end{cases} \\
& \mu_{i}(b)=\pi_{i}(b) \cdot \max 2\left\{b_{j}: j=1, . ., N\right\} .
\end{aligned}
$$

Harmad áras: Egy $b=\left(b_{1}, \ldots, b_{N}\right)$ licit vektor mellett

$$
\begin{aligned}
& \pi_{i}(b)= \begin{cases}1 & , \text { ha } b_{i}>b_{j} \forall j \neq i \\
0 & , \text { egyébként, }\end{cases} \\
& \mu_{i}(b)=\pi_{i}(b) \cdot \max 2\left\{b_{j}: i \neq j, j=1, \ldots, N\right\} .
\end{aligned}
$$

Mindenki fizet: Egy $b=\left(b_{1}, \ldots, b_{N}\right)$ licit vektor mellett

$$
\begin{aligned}
& \pi_{i}(b)= \begin{cases}1 & , \text { ha } b_{i}>b_{j} \forall j \neq i \\
0 & , \text { egyébként, }\end{cases} \\
& \mu_{i}(b)=b_{i} .
\end{aligned}
$$

Vesztes fizet: Egy $b=\left(b_{1}, \ldots, b_{N}\right)$ licit vektor mellett

$$
\begin{aligned}
& \pi_{i}(b)= \begin{cases}1 & , \text { ha } b_{i}>b_{j} \forall j \neq i \\
0 & , \text { egyébként }\end{cases} \\
& \mu_{i}(b)=\left(1-\pi_{i}(b)\right) b_{i} .
\end{aligned}
$$


Kivéreztetés: Egy $b=\left(b_{1}, \ldots, b_{N}\right)$ licit vektor mellett

$$
\begin{aligned}
\pi_{i}(b) & = \begin{cases}1 & , \text { ha } b_{i}>b_{j} \forall j \neq i ; \\
0 & , \text { egyébként, }\end{cases} \\
\mu_{i}(b) & = \begin{cases}\max _{j \neq i} b_{j} & , \text { ha } b_{i}>b_{j} \\
b_{i} & , \text { egyébként. }\end{cases}
\end{aligned}
$$

9.2. definíció (stratégia). Legyen $(\mathscr{B}, \pi, \mu)$ egy mechanizmus. Tegyük fel, hogy minden $i$ játékosra adott egy $\beta_{i}:\left[0, \omega_{i}\right] \rightarrow \mathbb{R}$ licitfüggvény. Azt mondjuk, hogy a $\left(\beta_{1}, \ldots, \beta_{N}\right)$ licitrendszer a mechanizmus egy stratégiája, ha a

$$
\beta(x)=\left(\beta_{1}\left(x_{1}\right), \beta_{2}\left(x_{2}\right), \ldots, \beta_{N}\left(x_{N}\right)\right)
$$

definícióval bevezetett együttes licitfüggvény értékei a $\mathscr{B}$ halmazba esnek, azaz, ha $\beta: \Xi \rightarrow \mathscr{B}$.

9.3. definíció (igazmondás stratégia). Amennyiben az értékelések halmaza a szignál halmaz részhalmaza, azaz $\Xi \subseteq \mathscr{B}$, a $\beta: \Xi \rightarrow \mathscr{B}, \beta(x)=x$ identitás függvény egy stratégia és ezt nevezzük az igazmondás stratégiának.

Jelölésbeli kellemetlenség, hogy amennyiben $\beta: \mathbb{R}^{N} \rightarrow \mathbb{R}^{N}$ egy függvény, akkor az $i$-edik koordináta függvényt $\beta_{i}: \mathbb{R}^{N} \rightarrow \mathbb{R}$ módon szokás jelölni, azaz a $\beta_{i}(x) \in \mathbb{R}$ szám a $\beta(x) \in \mathbb{R}^{N}$ vektor $i$-edik koordinátája. Itt viszont éppen fordítva a $\beta_{i}$ függvények adottak a $\beta$ definíciója előtt, és ezek segítségével definiáltuk $\beta$-t. Formálisan tehát a $\beta_{i}$ jel két különböző objektumot jelöl. Ha $\beta_{i}$ argumentuma egy $x$ vektor, akkor $\beta_{i}(x)$ a fent bevezetett együttes licitfüggvény $i$-edik koordináta függvényének értékét jelöli, ha pedig $\beta_{i}$ argumentuma egy $x_{i}$ szám, akkor $\beta_{i}\left(x_{i}\right)$ az $i$-edik játékosnak az $x_{i}$ értékeléséhez tartozó licitjét jelenti.

Ilyen módon minden $x=\left(x_{1}, \ldots, x_{N}\right) \in \Xi$ értékelés mellett

$$
\beta_{i}(x)=\beta_{i}\left(x_{i}\right) .
$$

Ennek megfelelően $\beta_{-i}\left(x_{-i}\right) \in \mathbb{R}^{N-1}$ azt a vektort jelöli, amelyet a $\beta(x)=$ $\left(\beta_{1}\left(x_{1}\right), \ldots, \beta_{N}\left(x_{N}\right)\right) \in \mathbb{R}^{N}$ vektor $i$-edik koordinátájának elhagyásával kapunk.

9.4. definíció (egyensúlyi stratégia). A $\beta: \Xi \rightarrow \mathscr{B}$ stratégia egy egyensúlyi stratégiája a $(\mathscr{B}, \pi, \mu)$ mechanizmusnak, ha minden $x=\left(x_{1}, \ldots, x_{N}\right) \in \Xi$ értékelésre és minden $i$ játékosra a

$$
b \mapsto \pi_{i}(b) x_{i}-\mu_{i}(b)
$$

$\mathscr{B} \rightarrow \mathbb{R}$ függvénynek a $b=\beta(x)$ pontban az $i$-edik koordináta irányában maximuma van. Ez azt jelenti, hogy minden $i$ mellett a

$$
\pi_{i}(\beta(x)) x_{i}-\mu_{i}(\beta(x)) \geq \pi_{i}\left(\beta_{-i}\left(x_{-i}\right), b_{i}\right) x_{i}-\mu_{i}\left(\beta_{-i}\left(x_{-i}\right), b_{i}\right)
$$

egyenlőtlenség minden $b_{i}$ mellett fennáll, amelyre $\left(\beta_{-i}\left(x_{-i}\right), b_{i}\right) \in \mathscr{B}$. 
9.5. definíció. $\mathrm{Az}(\mathscr{B}, \pi, \mu)$ mechanizmus $\beta$ egyensúlyi stratégiája melletti egyensúlyi kimenetek halmaza, az

$$
\{(\pi(\beta(x)), \mu(\beta(x))): x \in \Xi\} \subseteq[0,1]^{N} \times \mathbb{R}^{N}
$$

halmaz.

A 9.1 függvény interpretációja nyilvánvaló. A $b \in \mathscr{B}$ licit helyzetben $\pi_{i}(b)$ az $i$ játékos nyerési valószínűsége, tehát a $b$ licit vektor az $i$ számára $\pi_{i}(b) \cdot x_{i}$ bevételt jelent, ami $\mu_{i}(b)$ kiadással jár. Így a fent kiemelt 9.1 voltaképpen a kockázatok iránt semleges $i$ játékos profitja a licitvektor függvényében.

A profitfüggvény eddigi jelöléseivel összhangba jutunk, ha bevezetjük az $i$-edik játékos profitfüggvényét valamely rögzített $\beta=\left(\beta_{1}, \ldots, \beta_{N}\right)$ licitfüggvények mellett. Jelölje

$$
\Pi_{i}\left(b_{i}, x_{i}\right)=\pi_{i}\left(\beta_{-i}\left(x_{-i}\right), b_{i}\right) x_{i}-\mu\left(\beta_{-i}\left(x_{-i}\right), b_{i}\right),
$$

ahol $x_{-i} \in \Xi_{-i}$ rögzítve van.

A $\Pi_{i}\left(b_{i}, x_{i}\right)$ azt fejezi ki, hogy ha a $j \neq i$ játékosok az ő $x_{j}$ értékelésük esetén a $\beta_{j}\left(x_{j}\right)$ szignált mint licitet közvetítik, akkor az $i$ játékos $b_{i}$ licitje az $i$ játékos számára $\Pi_{i}\left(b_{i}, x_{i}\right)$ profitot eredményez.

A definíciót úgy is fogalmazhatjuk, hogy a $\beta$ pontosan akkor egyensúlyi licitrendszer, ha az értékelések minden $x \in \Xi, x=\left(x_{1}, \ldots, x_{N}\right)$ esetére a

$$
b_{i} \mapsto \Pi_{i}\left(b_{i}, x_{i}\right)
$$

függvényeknek $b_{i}=\beta_{i}\left(x_{i}\right)$ pontban maximuma van, valamennyi $i=1, \ldots, N$ játékos mellett.

\subsection{Revelációs elv}

9.6. definíció (direkt-mechanizmus). Egy mechanizmust direkt-mechanizmusnak nevezünk, ha a szignál halmaz azonos az értékelések halmazával. Egy direkt-mechanizmus szignál halmazát nem szokás kiírni, így ha $(Q, M)$ jelöli a direkt-mechanizmust, akkor $Q: \Xi \rightarrow \mathbb{R}^{N}$ az allokációs szabály, és $M: \Xi \rightarrow \mathbb{R}^{N}$ a befizetési szabály.

Érdemes felírni, hogy mit jelent egy direkt-mechanizmusban, ha az igazmondás egy egyensúlyi stratégia. Minden $x \in \Xi$ értékelésre és minden $i$ játékosra a

$$
Q_{i}(x) x_{i}-M_{i}(x) \geq Q_{i}\left(x_{-i}, t\right) x_{i}-M\left(x_{-i}, t\right)
$$

egyenlőtlenség minden $t \in\left[0, \omega_{i}\right]$ mellett teljesül. 
9.7. állítás. Legyen $\beta$ a $(\mathscr{B}, \pi, \mu)$ mechanizmus egy egyensúlyi stratégiája. Jelölje

$$
Q=\pi \circ \beta \quad \text { és } \quad M=\mu \circ \beta .
$$

Ekkor $(Q, M)$ olyan direkt-mechanizmus, melynek az igazmondás egy egyensúlyi stratégiája, és a $(\mathscr{B}, \pi, \mu)$ mechanizmus $\beta$ egyensúlyi stratégiáihoz tartozó egyensúlyi kimenetelek azonosak a $(Q, M)$ direkt-mechanizmus igazmondás melletti egyensúlyi $k i$ meneteleivel.

Bizonyitás. Azt kell megmutatnunk, hogy bárhogy is rögzítsük az $x \in \Xi$ értékelésvektort, úgy minden $i$ játékosra a $t \in\left[0, \omega_{i}\right]$

$$
t \mapsto Q_{i}\left(x_{-i}, t\right) x_{i}-M_{i}\left(x_{-i}, t\right)
$$

függvény az $x_{i}$ pontban maximális. No de azt tudjuk, hogy $\beta$ egyensúlyi stratégia, ezért

$$
\pi_{i}(\beta(x)) x_{i}-\mu_{i}(\beta(x)) \geq \pi_{i}\left(\beta_{-i}\left(x_{-i}\right), \beta_{i}(t)\right) x_{i}-\mu_{i}\left(\beta_{-i}\left(x_{-i}\right), \beta_{i}(t)\right) .
$$

Mivel a $Q=\pi \circ \beta$ kompozíció $i$-edik koordináta függvénye $\pi_{i} \circ \beta$, és az $M=\mu \circ \beta$ kompozíció $i$-edik koordináta függvénye $\mu_{i} \circ \beta$, ezért a jobb oldal ekvivalens a

$$
\pi_{i}\left(\beta\left(x_{-i}, t\right)\right) x_{i}-\mu_{i}\left(\beta\left(x_{-i}, t\right)\right)=Q_{i}\left(x_{-i}, t\right) x_{i}-M_{i}\left(x_{-i}, t\right)
$$

kifejezéssel, míg a bal oldal ekvivalens átalakítása:

$$
Q_{i}(x) x_{i}-M_{i}(x)=Q_{i}\left(x_{-i}, x_{i}\right) x_{i}-M_{i}\left(x_{-i}, x_{i}\right) .
$$

Pont ezt kellett belátnunk.

A $(Q, M)$ persze egy direkt-mechanizmus, amelynek az igazmondó stratégiához tartozó egyensúlyi kimenetelei a $(Q(x), M(x))=(\pi(\beta(x)), \mu(\beta(x)))$ alakú párok. 
10.

ÖSZTÖNZŐ MECHANIZMUS 

HA A JÁTÉKOS $p$ valószínúséggel nyeri a számára $x$ értékű tárgyat, és ehhez $m$ várható befizetés társul, akkor a profitja

$$
q x-m \text {. }
$$

Hasonlóan, ha $q(z)$ jelöli a tárgy megnyerésének valószínúségét, a $z$ szinten kinyilvánított kiértékelés mellett, és ha $m(z)$ a $z$ értékelés implikálta várható költség, akkor

$$
q(z) x-m(z)
$$

a várható profitja annak a licitálónak, aki $x$ értékeléssel rendelkezik, de $x$ helyett $z$-re cseréli értékelése kinyilvánítását.

A revelációs elv motivációja szerint szép lenne, ha ennek a függvénynek mindig $z=x$-ben maximuma lenne. Ez azonban nem minden direkt-mechanizmusra áll fenn.

A fejezet arról szól, hogy ez a racionalitási elvárásunk lényegében éppen azokra az aukciókra teljesül, amelyekre a bevételekvivalencia-elvet is általánosítani tudjuk.

\subsection{Az ösztönző mechanizmus definíciója}

10.1. definíció. Legyen $(Q, M)$ egy direkt-mechanizmus. Definiálja $q_{i}:\left[0, \omega_{i}\right] \rightarrow \mathbb{R}$ és $m_{i}:\left[0, \omega_{i}\right] \rightarrow \mathbb{R}$ az alábbi függvényeket

$$
\begin{aligned}
& q_{i}(z)=E\left(Q_{i}\left(z, X_{-i}\right)\right)=\int_{\Xi_{-i}} Q_{i}\left(z, x_{-i}\right) f_{-i}\left(x_{-i}\right) d x_{-i}, \\
& m_{i}(z)=E\left(M_{i}\left(z, X_{-i}\right)\right)=\int_{\Xi_{-i}} M_{i}\left(z, x_{-i}\right) f_{-i}\left(x_{-i}\right) d x_{-i} .
\end{aligned}
$$

10.2. definíció (ösztönző mechanizmus). Egy $(Q, M)$ direkt-mechanizmust ösztönzóonek nevezünk, ha minden $i=1, \ldots, N$ mellett és minden $x_{i} \in\left[0, \omega_{i}\right]$-re a

$$
z_{i} \mapsto q_{i}\left(z_{i}\right) x_{i}-m_{i}\left(z_{i}\right)
$$

függvény $x_{i}$-ben veszi fel a $\left[0, \omega_{i}\right]$ intervallum feletti maximumát.

Természetesen merül fel a kérdés, hogy adjunk példát $m, q:[0, \omega] \rightarrow \mathbb{R}$ függvényekre, amelyre igaz, hogy a

$$
z \mapsto q(z) x-m(z)
$$

függvény éppen $x$-ben maximális, de tetszőleges $x \in[0, \omega]$ mellett. Ha még differenciálhatóságot is felteszünk, akkor a szélsőérték elsőrendű feltételéből azonnal kapjuk, hogy ilyen függvényekre $m^{\prime}(x)=q^{\prime}(x) x$ szükségképpen fennáll, amiből

$$
m(x)-m(0)=\int_{0}^{x} m^{\prime}(t) d t=\int_{0}^{x} q^{\prime}(t) t d t=q(x) x-\int_{0}^{x} q(t) d t
$$

adódik egy parciális integrálás után. 
Most azt mutatjuk meg, hogy ha $q$ még monoton növekedô is, akkor a fenti szükséges feltétel már elegendővé válik. Mi több, a $(q, m)$ függvény páros pontosan akkor teljesíti a szóban forgó racionalitási feltételt, ha $q$ egy monoton növekedő függvény és

$$
m(x)=m(0)+q(x) x-\int_{0}^{x} q(z) d z
$$

fennáll minden $x \in[0, \omega]$ mellett.

Összefoglalásképpen azt mondhatjuk tehát, hogy csak monoton növekedő $q$ mellett van esély a $(q, m)$ racionalitására és ekkor $m$ konstanstól eltekintve egyértelmúen meghatározott a $q$ által.

\subsection{Kapcsolat a bevételekvivalencia-elvvel}

Egy direkt-mechanizmus ösztönzőségének ekvivalens felírásai következnek.

10.3. definíció (egyensúlyi hasznosság függvény, vagy várható egyensúlyi hasznosság függvény). Definiálja minden $i=1, \ldots, N$ mellett

$$
U_{i}\left(x_{i}\right)=q_{i}\left(x_{i}\right) x_{i}-m_{i}\left(x_{i}\right)
$$

az egyensúlyi hasznosság függvényt.

10.4. állítás. Egy $(Q, M)$ direkt-mechanizmus mellett az alábbi feltételek egymással ekvivalensek.

1. $(Q, M)$ egy ösztönzö direkt-mechanizmus,

2. Minden i játékosra és bármely két $x_{i}, z_{i} \in\left[0, \omega_{i}\right]$ értékelésre

$$
U_{i}\left(x_{i}\right) \geq q_{i}\left(z_{i}\right) x_{i}-m_{i}\left(z_{i}\right),
$$

3. Minden i játékosra és minden $x_{i} \in\left[0, \omega_{i}\right]$ értékelésre az $\left(x_{i}, U_{i}\left(x_{i}\right)\right)$ pontban húzott $q_{i}\left(x_{i}\right)$ meredekségü egyenes egy támaszegyenese az $U_{i}$ függvénynek, azaz minden $z_{i} \in\left[0, \omega_{i}\right]$ mellett

$$
U_{i}\left(z_{i}\right) \geq U_{i}\left(x_{i}\right)+q_{i}\left(x_{i}\right)\left(z_{i}-x_{i}\right),
$$

4. Minden i mellett a

a) qi függvény monoton növő, és

b) $U_{i}$ függvény a $q_{i}$ egy integrálfüggvénye, azaz minden $x_{i} \in\left[0, \omega_{i}\right]$ értékelésre

$$
U_{i}\left(x_{i}\right)=U_{i}(0)+\int_{0}^{x_{i}} q_{i}(z) d z
$$




\section{Minden i mellett a}

a) qi függvény monoton növö, és

b) teljesül a REP egyenlôség, azaz minden $x_{i} \in\left[0, \omega_{i}\right]$ értékelésre

$$
m_{i}\left(x_{i}\right)=m_{i}(0)+q_{i}\left(x_{i}\right) x_{i}-\int_{0}^{x_{i}} q_{i}(z) d z
$$

Bizonyítás. Az állítások ekvivalens voltát körbe igazoljuk. A bizonyítás az $\mathbb{R} \rightarrow \mathbb{R}$ függvények konvexitásának jellemzésén alapul. 1

$1 \rightarrow 2$ : A feltevés, hogy tetszőleges $x_{i}$ mellett a $z_{i} \mapsto q_{i}\left(z_{i}\right) x_{i}-m_{i}\left(z_{i}\right)$ függvény éppen $x_{i}$-ben vesz fel maximumát azt jelenti, hogy

$$
q_{i}\left(z_{i}\right) x_{i}-m_{i}\left(z_{i}\right) \leq q_{i}\left(x_{i}\right) x_{i}-m_{i}\left(x_{i}\right)=U_{i}\left(x_{i}\right) .
$$

$2 \rightarrow 3$ : Mivel a fenti egyenlőtlenség minden $x_{i}, z_{i} \in\left[0, \omega_{i}\right]$ mellett fennáll, ezért a két változót felcserélve

$$
\begin{array}{r}
U_{i}\left(z_{i}\right) \geq q_{i}\left(x_{i}\right) z_{i}-m_{i}\left(x_{i}\right)=q_{i}\left(x_{i}\right) z_{i}-q_{i}\left(x_{i}\right) x_{i}+q_{i}\left(x_{i}\right) x_{i}-m_{i}\left(x_{i}\right)= \\
U_{i}\left(x_{i}\right)+q_{i}\left(x_{i}\right)\left(z_{i}-x_{i}\right) .
\end{array}
$$

$3 \rightarrow 4$ : Az $U_{i}$ függvénynek tehát minden $x_{i}$ pontban van támaszegyenese, melynek meredeksége $q_{i}\left(x_{i}\right)$. Az $U_{i}$ tehát egy konvex függvény, amelynek bal- és jobboldali deriváltja közt van $q_{i}\left(x_{i}\right)$. Mivel egy konvex függvénynek mind a bal- mind a jobboldali deriváltja monoton nő, ezért $q_{i}$ is monoton nő. Monoton növő függvény Riemannintegrálható és tudjuk, hogy egy konvex függvény tetszőleges a bal- és a jobb oldali deriváltja közti függvény integrálfüggvénye.

$4 \rightarrow 5$ : Kiindulva abból, hogy $U_{i}$ a $q_{i}$ egy integrálfüggvénye azt kapjuk, hogy

$$
q_{i}\left(x_{i}\right) x_{i}-m_{i}\left(x_{i}\right)=U_{i}\left(x_{i}\right)=U_{i}(0)+\int_{0}^{x_{i}} q_{i}\left(z_{i}\right) d z_{i}=-m_{i}(0)+\int_{0}^{x_{i}} q_{i}\left(z_{i}\right) d z_{i} .
$$

Ezt átrendezve éppen a REP azonosságot kapjuk.

\footnotetext{
${ }^{1}$ Mivel nem teljesen közismert az a tény, hogy egy ilyen függvény pontosan akkor konvex, ha valamely a bal- és a jobb oldali deriváltja közti függvény integrálfüggvénye, ezért a függelék tartalmazza ennek rövid tárgyalását.
} 
$5 \rightarrow 1$ : Először is felírva a $(\mathrm{REP})$ azonosságot tetszőleges $z_{i}, x_{i} \in\left[0, \omega_{i}\right]$ mellett

$$
\begin{aligned}
& m_{i}\left(z_{i}\right)=m_{i}(0)+z_{i} q_{i}\left(z_{i}\right)-\int_{0}^{z_{i}} q_{i}(t) d t, \\
& m_{i}\left(x_{i}\right)=m_{i}(0)+x_{i} q_{i}\left(x_{i}\right)-\int_{0}^{x_{i}} q_{i}(t) d t .
\end{aligned}
$$

A két egyenlet különbségét képezve

$$
m_{i}\left(z_{i}\right)-m_{i}\left(x_{i}\right)=z_{i} q_{i}\left(z_{i}\right)-x_{i} q_{i}\left(x_{i}\right)-\int_{x_{i}}^{z_{i}} q_{i}(t) d t .
$$

No de a $q_{i}$ függvények monotonitása szerint

$$
\int_{x_{i}}^{z_{i}} q_{i}(t) d t \leq q_{i}\left(z_{i}\right)\left(z_{i}-x_{i}\right),
$$

tehát folytatva

$$
m_{i}\left(z_{i}\right)-m_{i}\left(x_{i}\right) \geq z_{i} q_{i}\left(z_{i}\right)-x_{i} q_{i}\left(x_{i}\right)-q_{i}\left(z_{i}\right)\left(z_{i}-x_{i}\right)=q_{i}\left(z_{i}\right) x_{i}-x_{i} q_{i}\left(x_{i}\right) .
$$

Ezt átrendezve kapjuk, hogy

$$
x_{i} q_{i}\left(x_{i}\right)-m_{i}\left(x_{i}\right) \geq q_{i}\left(z_{i}\right) x_{i}-m_{i}\left(z_{i}\right),
$$

ami éppen azt jelenti, hogy az $z_{i} \mapsto q_{i}\left(z_{i}\right) x_{i}-m_{i}\left(z_{i}\right)$ függvény az $x_{i}$ pontban maximális.

Ezt kellett belátni.

A fenti igazolásból látható, hogy egy ösztönző mechanizmus egyensúlyi hasznosság függvényei konvex és monoton növő függvények, amelyekre $U_{i}(0)=-m_{i}(0)$.

A fenti ekvivalens feltevések közül az 5.-re tekintünk úgy, mint a bevételekvivalencia-elv általánosítására. A REP azonosságot ugyanis úgy interpretálhatjuk, hogy ösztönző $(Q, M)$ direkt-mechanizmus mellett az $m_{i}$ várható befizetés lényegében csak a $Q$ allokációs szabálytól függ: Adott $Q$ allokáció mellett tetszőleges olyan $M$ befizetési szabállyal, amely $(Q, M)$ mechanizmust ösztönzővé teszi, a kapott $m_{i}$ várható befizetések alakja ugyanaz, ezek egymástól csak egy konstans eltolásban különböznek.

\subsection{Egzisztencia}

Miután szép, szükséges és elégséges feltételeket találtunk egy direkt-mechanizmus ösztönzó voltára, rátérünk annak vizsgálatára, hogy adott allokációs szabályhoz milyen feltételek mellett definiálható olyan befizetési szabály, amellyel a kapott direktmechanizmus ösztönzővé válik. Jól használható elegendő feltételt kapunk: Ha az allokációs szabály olyan, hogy a többiek fix értékelése mellett nagyobb értékelés nem csökkenti az aktuális licitáló nyerési valószínúségét, akkor mindig definiálható olyan befizetési függvény, amely a mechanizmust ösztönzővé varázsolja. 
10.5. állítás. Legyen $Q$ egy tetszóleges allokációs szabály.

1. Definiálja

$$
M_{i}(x)=Q_{i}(x) x_{i}-\int_{0}^{x_{i}} Q_{i}\left(z, x_{-i}\right) d z .
$$

Ha $M=\left(M_{1}, \ldots, M_{N}\right)$, akkor a $(Q, M)$ direkt-mechanizmusban $m_{i}(0)=0$-val áll fenn a REP azonosság, tehát minden $x_{i} \in\left[0, \omega_{i}\right]$ mellett

$$
m_{i}\left(x_{i}\right)=q_{i}\left(x_{i}\right) x_{i}-\int_{0}^{x_{i}} q_{i}(z) d z
$$

teljesül.

2. A $Q$ allokációs szabályhoz pontosan akkor található olyan $M$ befizetési szabály, melyre a $(Q, M)$ mechanizmus ösztönzó, ha a q függvények monoton nönek minden $i$ mellett.

3. Speciálisan, ha minden i mellett és minden rögzített $x_{-i} \in \Xi_{-i}$ vektor esetén a

$$
z \mapsto Q_{i}\left(z, x_{-i}\right)
$$

függvény monoton növó, akkor a fenti M befizetés szabállyal $(Q, M)$ egy ösztönzó direkt-mechanizmus.

Bizonyítás. Definíció szerint $m_{i}\left(x_{i}\right)=\int_{\Xi_{-i}} M\left(x_{i}, x_{-i}\right) f_{-i}\left(x_{-i}\right) d x_{-i}$. Így a Fubini-tétel és $q_{i}$ definíciója miatt

$$
\begin{aligned}
& m_{i}\left(x_{i}\right)=\int_{\Xi_{-i}}\left(x_{i} Q_{i}\left(x_{i}, x_{-i}\right)-\int_{0}^{x_{i}} Q_{i}\left(z, x_{-i}\right) d z\right) f_{-i}\left(x_{-i}\right) d x_{-i}= \\
& x_{i} \int_{\Xi_{-i}} Q_{i}\left(x_{i}, x_{-i}\right) f_{-i}\left(x_{-i}\right) d x_{-i}-\int_{\Xi_{-i}} \int_{0}^{x_{i}} Q_{i}\left(z, x_{-i}\right) f_{-i}\left(x_{-i}\right) d z d x_{-i}= \\
& \quad x_{i} q_{i}\left(x_{i}\right)-\int_{0}^{x_{i}} \int_{\Xi_{-i}} Q_{i}\left(z, x_{-i}\right) f_{-i}\left(x_{-i}\right) d x_{-i} d z=x_{i} q_{i}\left(x_{i}\right)-\int_{0}^{x_{i}} q_{i}(z) d z .
\end{aligned}
$$

Teljesül tehát a bizonyítandó egyenlőség.

Összefoglalva: ha $q_{i}$ függvények monoton növők, akkor a befizetési függvény fenti definíciójával teljesül az előző állítás 5. pontja, ergo a definiált $(Q, M)$ direktmechanizmus ösztönző.

Fordítva, ha valahogyan definiálható az adott allokációs szabályhoz olyan befizetési szabály, amellyel a kapott direkt-mechanizmus ösztönző, akkor szintén az előző állítás 4. vagy 5. pontja miatt valamennyi $q_{i}$ függvény monoton növő.

Legyen most $x_{-i} \in \Xi_{-i}$ és $0 \leq z<w \leq \omega_{i}$. Ekkor $Q\left(z, x_{-i}\right) f_{-i}\left(x_{-i}\right) \leq$ $Q\left(w, x_{-i}\right) f_{-i}\left(x_{-i}\right)$, ezért e függvények $\Xi_{-i}$ feletti integráljaira is igaz ez az egyenlőtlenség, ami éppen azt jelenti, hogy $q_{i}(z) \leq q_{i}(w)$. Ezt kellett belátni. 


\subsection{A kikiáltó bevétele}

Mivel a kikiáltó bevétele egészen nyilvánvaló módon csak az aukció résztvevőitôl származik, azaz csak az $m_{i}$ várható befizetési függvényektôl függ, továbbá az $m_{i}$ befizetések konstanstól eltekintve csak a $Q$ allokációtól függenek egy ösztönző mechanizmus mellett, ezért a kikiáltó várható árbevételét is meghatározza a $Q$ allokációs szabály, ahogyan azt korábban a bevételekvivalencia-elvet kielégítő konkrét aukcióknál is láttuk. Az állításnak fontos érdekessége, hogy újra megjelenik a virtuális értékelés koncepciója. Később ennek a gondolatnak az alapján kapjuk a virtuális értékelés érdekes interpretációit. Az állítás igazolása után ennek egy előrehozott példáját adjuk, arra a már vizsgált esetre vonatkozólag, amikor a licitálók azonos értékeloszlással rendelkeznek.

10.6. állítás. Legyen $(Q, M)$ egy ösztönző direkt-mechanizmus. Ekkor a kikiáltónak az i-edik játékostól származó várható haszna

$$
E\left(m\left(X_{i}\right)\right)=m_{i}(0)+\int_{\Xi} Q_{i}(x) f(x) \psi_{i}\left(x_{i}\right) d x,
$$

ahol $\psi_{i}$ az i játékos virtuális értékelése. Így a kikiáltó várható bevételére

$$
E(R)=\sum_{i=1}^{N} E\left(m_{i}\left(X_{i}\right)\right)=\sum_{i=1}^{N} m_{i}(0)+\int_{\Xi}\left(\sum_{i=1}^{N} Q_{i}(x) \psi_{i}\left(x_{i}\right)\right) f(x) d x .
$$

Bizonyítás. Láttuk, hogy ösztönző mechanizmusra teljesül a bevételekvivalencia-elv, tehát minden $i$ játékosra és annak minden $x_{i} \in\left[0, \omega_{i}\right]$ értékelésére

$$
m_{i}\left(x_{i}\right)=m_{i}(0)+q_{i}\left(x_{i}\right) x_{i}-\int_{0}^{x_{i}} q_{i}(z) d z .
$$

A transzformált valószínűségi változó formulája miatt, ezért

$$
\begin{aligned}
& E\left(m_{i}\left(X_{i}\right)\right)=\int_{0}^{\omega_{i}} m_{i}\left(x_{i}\right) f_{i}\left(x_{i}\right) d x_{i}= \\
& \quad \int_{0}^{\omega_{i}} m_{i}(0) f_{i}\left(x_{i}\right) d x_{i}+\int_{0}^{\omega_{i}} q_{i}\left(x_{i}\right) x_{i} f_{i}\left(x_{i}\right) d x_{i}-\int_{0}^{\omega_{i}} \int_{0}^{x_{i}} q_{i}(z) d z f_{i}\left(x_{i}\right) d x_{i} .
\end{aligned}
$$

A kettős integrál a Fubini-tétel miatt

$$
\begin{gathered}
\int_{0}^{\omega_{i}} \int_{0}^{x_{i}} q_{i}(z) d z f_{i}\left(x_{i}\right) d x_{i}=\int_{0}^{\omega_{i}} \int_{0}^{\omega_{i}} \chi_{\left[0, x_{i}\right]}(z) q_{i}(z) f_{i}\left(x_{i}\right) d z d x_{i}= \\
\int_{0}^{\omega_{i}} \int_{0}^{\omega_{i}} \chi_{\left[z, \omega_{i}\right]}\left(x_{i}\right) q_{i}(z) f_{i}\left(x_{i}\right) d x_{i} d z=\int_{0}^{\omega_{i}} q_{i}(z) \int_{z}^{\omega_{i}} f_{i}\left(x_{i}\right) d x_{i} d z= \\
\int_{0}^{\omega_{i}} q_{i}(z)\left(1-F_{i}(z)\right) d z .
\end{gathered}
$$


A virtuális értékelés $\psi_{i}=\mathrm{id}-\frac{1-F_{i}}{f_{i}}$ bevezetésével folytatva, majd újra a Fubini-tételt használva kapjuk kívánt formulát.

$$
\begin{aligned}
E\left(m\left(X_{i}\right)\right) & =m_{i}(0)+\int_{0}^{\omega_{i}} q_{i}\left(x_{i}\right) x_{i} f_{i}\left(x_{i}\right)-q_{i}\left(x_{i}\right)\left(1-F_{i}\left(x_{i}\right)\right) d x_{i} \\
& =m_{i}(0)+\int_{0}^{\omega_{i}} q_{i}\left(x_{i}\right) f_{i}\left(x_{i}\right)\left(x_{i}-\frac{1-F_{i}\left(x_{i}\right)}{f_{i}\left(x_{i}\right)}\right) d x_{i} \\
& =m_{i}(0)+\int_{0}^{\omega_{i}} q_{i}\left(x_{i}\right) f_{i}\left(x_{i}\right) \psi_{i}\left(x_{i}\right) d x_{i} \\
& =m_{i}(0)+\int_{0}^{\omega_{i}}\left(\int_{\Xi_{-i}} Q_{i}\left(x_{i}, x_{-i}\right) f_{-i}\left(x_{-i}\right) d x_{-i}\right) f_{i}\left(x_{i}\right) \psi_{i}\left(x_{i}\right) d x_{i} \\
& =m_{i}(0)+\int_{\Xi} Q_{i}(x) f(x) \psi_{i}\left(x_{i}\right) d x .
\end{aligned}
$$

Ezek összegére felírt formula már nyilvánvaló.

Mielőtt folytatnánk az aszimmetrikus eset vizsgálatát, magunknak egy pillanat kitérőt megengedve, alkalmazzuk a fenti eredményt szimmetrikus helyzetben, reguláris játékosokkal. Például egy másodáras aukcióra is teljesülnek az alábbi feltételek.

10.7. megjegyzés. Legyen most a $(Q, M)$ ösztönző direkt-mechanizmus hatékony. Tegyük fel, hogy a játékosok eloszlása azonos, és a közös virtuális értékelésük szigorúan monoton növő függvény. Ekkor

$$
\sum_{i=1}^{N} Q_{i}(x) \psi\left(x_{i}\right)=\max \left\{\psi\left(x_{1}\right), \psi\left(x_{2}\right), \ldots, \psi\left(x_{N}\right)\right\},
$$

ezért ha még azt is feltesszük, hogy $m_{i}(0)=0$ minden játékos mellett, akkor

$$
E(R)=E\left(\max \left\{\psi\left(X_{1}\right), \psi\left(X_{2}\right), \ldots, \psi\left(X_{N}\right)\right\}\right) .
$$

Bizonyítás. A mechanizmus hatékonysága azt jelenti, hogy az aukció nyertese a legnagyobb értékelésú játékos, tehát

$$
Q_{i}(x)= \begin{cases}1 & , \text { ha } x_{i}>x_{j} \text { minden } i \neq j ; \\ 0 & , \text { egyébként. }\end{cases}
$$

Így $\sum_{i=1}^{N} Q_{i}(x) \psi_{i}\left(x_{i}\right)=\psi\left(x_{k}\right)$ arra a $k$ indexre, amelyre $x_{k}>x_{i}$ minden $i \neq k$ mellett. Persze a regularitás feltevése szerint $x_{k}>x_{i}$ ekvivalens $\psi\left(x_{k}\right)>\psi\left(x_{i}\right)$ feltétellel, így

$$
\sum_{i=1}^{N} Q_{i}(x) \psi\left(x_{i}\right)=\psi\left(x_{k}\right)=\max \left\{\psi\left(x_{1}\right), \ldots, \psi\left(x_{N}\right)\right\} .
$$

Ezt kellett belátni.

A nyilvánvaló értelmezés tehát, hogy a fenti esetben a kikiáltó várható bevétele úgy is tekinthető, mintha a virtuális értékelésekkel mint licitfüggvényekkel játszanának a játékosok egy elsőáras aukciót. 

OPTIMÁLIS MEGVALÓSÍTHATÓ
MECHANIZMUS 

A FEJEZETBEN AZT keressük, hogy bizonyos újabb észszerû racionalitási feltevés mellett, mi a kikiáltó várható hasznának maximuma. Ez a feltevés azt jelenti, hogy a licitálóktól nem elvárható, hogy megjelenjenek olyan aukción, amely számukra negatív hasznossággal jár.

\subsection{Megvalósítható direkt-mechanizmus}

Visszatérve az általános esetre, egy nyilvánvaló becslés adható a 10.6 állításbeli függvényre.

11.1. állítás. Tekintsük a $(Q, M)$ direkt-mechanizmust és legyen $\psi_{i}$ az i játékos virtuális értékelése. Ekkor

$$
\sum_{i=1}^{N} Q_{i}(x) \psi_{i}\left(x_{i}\right) \leq \max \left\{\psi_{1}\left(x_{1}\right), \psi_{2}\left(x_{2}\right), \ldots, \psi_{N}\left(x_{N}\right), 0\right\} .
$$

Bizonyítás. Világos, hogy $\psi_{i}\left(x_{i}\right) \leq \psi_{i}\left(x_{i}\right) \vee 0 \leq \max \left\{\psi_{k}\left(x_{k}\right) \vee 0: k=1, \ldots, N\right\}$. Így a $Q_{i}(x) \geq 0$ szerint

$$
\begin{aligned}
\sum_{i=1}^{N} Q_{i}(x) \psi_{i}\left(x_{i}\right) & \leq \sum_{i=1}^{N} Q_{i}(x) \max \left\{\psi_{k}\left(x_{k}\right) \vee 0: k=1, \ldots, N\right\} \\
& =\max \left\{\psi_{k}\left(x_{k}\right) \vee 0: k=1, \ldots, N\right\} \sum_{i=1}^{N} Q_{i}(x) \\
& \leq \max \left\{\psi_{k}\left(x_{k}\right) \vee 0: k=1, \ldots, N\right\} .
\end{aligned}
$$

Ezt kellett belátni.

11.2. definíció (egyénileg racionális). Azt mondjuk, hogy a $(Q, M)$ direktmechanizmus egyénileg racionális, ha minden $i$ mellett $U_{i} \geq 0$.

Egy ösztönző mechanizmus mellett $U_{i}\left(x_{i}\right)=U_{i}(0)+\int_{0}^{x_{i}} q_{i}(z) d z$. Mivel itt $q$ egy valószínúség, ergo nem negatív, ezért minden $U_{i}$ egy-egy monoton növő függvény. Így figyelembe véve az $U_{i}\left(x_{i}\right)=q_{i}\left(x_{i}\right) x_{i}-m_{i}\left(x_{i}\right)$ definíciót, $U_{i}(0)=-m_{i}(0)$. Emiatt az

$$
U_{i} \geq 0 ; \quad U_{i}(0) \geq 0 ; \quad m_{i}(0) \leq 0
$$

ekvivalens feltételek egy ösztönző mechanizmus mellett.

11.3. állítás. Egy $(Q, M)$ direkt-mechanizmus pontosan akkor egyszerre ösztönzó és egyénileg racionális, ha minden $i=1, \cdots, N$ mellett $a$

1. $q_{i}$ monoton növó,

2. $m_{i}\left(x_{i}\right)=m_{i}(0)+x_{i} q_{i}\left(x_{i}\right)-\int_{0}^{x_{i}} q_{i}(t) d t$, 
3. $m_{i}(0) \leq 0$

feltételek egyszerre teljesülnek.

11.4. definíció (megvalósítható). Egy direkt-mechanizmust megvalósíthatónak nevezünk, ha az ösztönző és egyénileg racionális.

Látjuk tehát, hogy egy megvalósítható mechanizmus annyival több, mint egy ösztönző mechanizmus, hogy kizárja az $m_{i}(0)>0$ eset lehetőségét. Ez úgy interpretálható, hogy a 0 értékelés mellett nem lehet pozitív a várható költség, ami annyit tesz, hogy minden játékos számára megengedett dolog az aukciótól való távolmaradás.

Az eddigi eredményeink összefoglalása a következô állítás.

11.5. álítás. Legyen $(Q, M)$ egy megvalósítható direkt-mechanizmus. Ekkor ennek várható bevételére

$$
E(R) \leq E\left(\max \left\{\psi_{1}\left(X_{1}\right), \psi_{2}\left(X_{2}\right), \ldots, \psi_{N}\left(X_{N}\right), 0\right\}\right) .
$$

Bizonyítás. Mivel ösztönzô a mechanizmus, ezért 10.6 állítás és a tetszőleges mechanizmusra is fennálló 11.1 állítás szerint

$$
\begin{gathered}
E(R) \leq \sum_{i=1}^{N} m_{i}(0)+\int_{\Xi} \max \left\{\psi\left(x_{1}\right), \psi\left(x_{2}\right), \ldots, \psi\left(x_{N}\right), 0\right\} f(x) d x= \\
\sum_{i=1}^{N} m_{i}(0)+E\left(\max \left\{\psi\left(X_{1}\right), \ldots, \psi\left(X_{N}\right), 0\right\}\right) .
\end{gathered}
$$

Ha a mechanizmus még egyénileg racionális is, akkor $m_{i}(0) \leq 0$, így a fenti összeg első tagja nem pozitív.

\subsection{Példa a kikiáltó számára maximális bevételt adó megvalósítható mechanizmusra}

Most arra törekszünk, hogy olyan megvalósítható direkt-mechanizmust konstruáljunk, amelyre a fenti egyenlőtlenség egyenlőséggel teljesül.

Elsố lépésként arra emlékezzünk, hogy tetszôleges allokációhoz definiálható olyan befizetési szabály, amivel a mechanizmus teljesíti a bevételekvivalencia-elvet. Ha az allokációs szabály még olyan is, hogy az $i$-edik értékelés növelésével az $i$-edik játékos nyerési valószínúsége nem csökken, akkor az így kapott mechanizmus ösztönzó.

A következő definíció egyben állítás is, ezért igazolásra szorul. 
11.6. definíció (optimális megvalósítható mechanizmus). Reguláris modell mellett

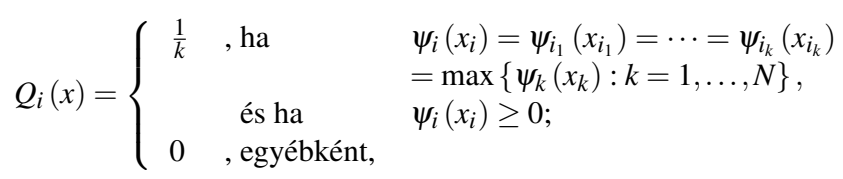

és

$$
M_{i}(x)=Q_{i}(x) x_{i}-\int_{0}^{x_{i}} Q_{i}\left(z, x_{-i}\right) d z .
$$

Legyen $M=\left(M_{1}, \ldots, M_{N}\right)$ és hasonlóan $Q=\left(Q_{1}, \ldots, Q_{N}\right)$.

Ekkor $(Q, M)$ egy olyan megvalósítható mechanizmus, amelyre $m_{i}(0)=0$ fennáll minden $i$ játékos mellett.

Bizonyítás. A $Q_{i}(x)=\frac{1}{k}$ azt jelenti, hogy a $\left(\psi_{1}\left(x_{1}\right), \psi_{2}\left(x_{2}\right), \ldots, \psi_{N}\left(x_{N}\right)\right)$ vektor koordinátái közül $\psi_{i}\left(x_{i}\right)$ az egyik legnagyobb és az $i$-ediket is beleértve éppen $k$ darab legnagyobb van, amelyek nem lehetnek negatívak. Így csak az

$$
\sum_{i=1}^{N} Q_{i}(x)=0 \quad \text { vagy } \quad \sum_{i=1}^{N} Q_{i}(x)=k \frac{1}{k}=1
$$

esetek fordulhatnak elő, ezért $Q$ valóban egy allokációs függvény. Így $(Q, M)$ egy mechanizmus, amelyre

$$
m_{i}(0)=0 \quad \text { és } \quad m_{i}\left(x_{i}\right)=m_{i}(0)+x_{i} q_{i}\left(x_{i}\right)-\int_{0}^{x_{i}} q_{i}(z) d z
$$

a 10.5 állítás szerint.

Most megmutatjuk, hogy minden rögzített $x_{i} \in \Xi_{-i}$ vektorra a

$$
z \mapsto Q_{i}\left(z, x_{-i}\right)
$$

függvény monoton növő. Legyen tehát $z<w$. Ha $Q_{i}\left(z, x_{-i}\right)=0$, akkor $Q_{i}\left(z, x_{-i}\right)=$ $0 \leq Q_{i}\left(w, x_{-i}\right)$ nyilvánvalóan fennáll. Ha viszont $Q_{i}\left(z, x_{-i}\right)=\frac{1}{k}$, akkor $\psi_{i}(z)<\psi_{i}(w)$ miatt $Q_{i}\left(w, x_{-i}\right)=1$. Ez azt jelenti, hogy $Q_{i}\left(z, x_{-i}\right) \leq 1=Q_{i}\left(w, x_{-i}\right)$ megint csak nyilvánvalóan teljesül. Innen már nyilvánvalóan következik a $q_{i}$ függvények monotonitása.

A 11.3 állítás szerint tehát a mechanizmus megvalósítható, sőt az $m_{i}(0)=0$ feltételek is teljesülnek.

Mivel a 10.6 állítás szerint a kikiáltó várható bevételére a

$$
E(R)=\sum_{i=1}^{N} m_{i}(0)+\int_{\Xi}\left(\sum_{i=1}^{N} Q_{i}(x) \psi_{i}\left(x_{i}\right)\right) f(x) d x
$$

formula áll fenn minden ösztönző mechanizmus mellett, ezért az teljesen nyilvánvaló, hogy a megvalósítható mechanizmusok körére szorítkozva, olyan mechanizmus biztosítja a kikiáltó maximális várható bevételét, amelyre $m_{i}(0)=0$ áll fenn minden licitáló 
mellett. Ebben az értelemben nyilvánvaló, hogy a 11.6 definícióban megadott példa egyben optimális mechanizmus is.

A következő állítás egyrészt ezt szögezi le, másrészt a virtuális értékelések segítségével megteremti annak lehetőségét, hogy jobban megértsük a 11.6 definíciót.

11.7. állítás. Reguláris modellben a 11.6. definícióban megadott megvalósítható mechanizmus adja a kikiáltó legnagyobb bevételét. A

$$
\max \{E(R):(Q, M) \text { megvalósítható mechanizmus }\}
$$

feladat a 11.6 definícióbeli mechanizmus mellett maximális és az értéke:

$$
E(R)=E\left(\max \left\{\psi_{1}\left(X_{1}\right), \psi_{2}\left(X_{2}\right), \ldots, \psi_{N}\left(X_{N}\right), 0\right\}\right) .
$$

Bizonyítás. $\mathrm{A} 11.5$ állítás szerint minden $(Q, M)$ megvalósítható mechanizmusra

$$
E(R) \leq E\left(\max \left\{\psi_{1}\left(X_{1}\right), \psi_{2}\left(X_{2}\right), \ldots, \psi_{N}\left(X_{N}\right), 0\right\}\right) .
$$

Legyen most $(Q, M)$ a 11.6 definíció szerint megadva. Először is vegyük észre, hogy valamely $i$ mellett $Q_{i}(x)>0$ pontosan akkor teljesül, ha $\psi_{i}\left(x_{i}\right)=$ $\max \left\{\psi_{1}\left(x_{1}\right), \ldots, \psi_{N}\left(x_{N}\right)\right\} \geq 0$. Emiatt

$$
\sum_{i=1}^{N} Q_{i}(x) \psi_{i}\left(x_{i}\right)=\max \left\{\psi_{1}\left(x_{1}\right), \ldots, \psi_{N}\left(x_{N}\right), 0\right\}
$$

Ugyanis, ha minden $i$ mellett $\psi_{i}\left(x_{i}\right)<0$, akkor a bal és a jobb oldal is zérus. Ha van olyan $i$, amelyre $\psi_{i}\left(x_{i}\right) \geq 0$, akkor

$$
\sum_{i=1}^{N} Q_{i}(x) \psi_{i}\left(x_{i}\right)=\sum_{\substack{i=1 \\ \psi_{i}\left(x_{i}\right) \geq 0}}^{N} Q_{i}(x) \psi_{i}\left(x_{i}\right)=k \frac{1}{k} \max \left\{\psi_{1}\left(x_{1}\right), \psi_{2}\left(x_{2}\right), \ldots, \psi_{N}\left(x_{N}\right)\right\}
$$

ahol $k$-szor fordul elő egyenlőség a $\left(\psi_{1}\left(x_{1}\right), \ldots, \psi_{N}\left(x_{N}\right)\right)$ vektorban. Így a kikiáltó várható bevételére $\mathrm{a} 10.6$ állítás szerint

$$
\begin{aligned}
& E(R)=\sum_{i=1}^{N} m_{i}(0)+\int_{\Xi}\left(\sum_{i=1}^{N} Q_{i}(x) \psi_{i}\left(x_{i}\right)\right) f(x) d x= \\
& \int_{\Xi} \max \left\{\psi_{1}\left(x_{1}\right), \ldots, \psi_{N}\left(x_{N}\right), 0\right\} f(x) d x=E\left(\max \left\{\psi_{1}\left(X_{1}\right), \ldots, \psi_{N}\left(X_{N}\right), 0\right\}\right) .
\end{aligned}
$$

Ezt kellett belátni. 


\subsection{Az optimális megvalósítható mechanizmus interpretációi}

Próbáljunk most a 11.6 definíció optimális megvalósítható mechanizmusához intuitív értelmezést találni. Az allokációs szabály jelentése nyilvánvaló. Adott $x=$ $\left(x_{1}, \ldots, x_{N}\right) \in \Xi$ értékelés vektor mellett írjuk fel a virtuális értékelés vektort: $\left(\psi_{1}\left(x_{1}\right), \ldots, \psi_{N}\left(x_{N}\right)\right) \in \mathbb{R}^{N}$. Ha minden virtuális értékelés negatív, akkor nem nyer senki. Ha van legalább zérus virtuális értékelés, akkor a legnagyobb virtuális értékelésû játékos nyer. Pontosabban ő 1 valószínúséggel nyer, ha egyedül birtokolja a legnagyobb virtuális értékelésú címet, de ha több ilyen is van, mondjuk $k$ darab, akkor $1 / k$ valószínûséggel nyernek a maximális virtuális értékelésű játékosok.

A befizetési szabályról annyit láttunk, hogy úgy van definiálva, hogy teljesítse a bevételekvivalencia-elvet. Nézzük most a befizetési szabály értelmezését. Definíció szerint ez

$$
M_{i}(x)=Q_{i}(x) x_{i}-\int_{0}^{x_{i}} Q_{i}\left(z, x_{-i}\right) d z .
$$

Diszkutáljuk tehát a $Q_{i}\left(\cdot, x_{-i}\right):\left[0, \omega_{i}\right] \rightarrow[0,1]$ függvényt. Ehhez vezessük be az $y_{i}$ : $\Xi_{-i} \rightarrow\left[0, \omega_{i}\right]$ függvényt:

$$
y_{i}\left(x_{-i}\right)=\min \left\{z_{i} \in\left[0, \omega_{i}\right]: \psi_{i}\left(z_{i}\right) \geq \psi_{j}\left(x_{j}\right) \forall j \neq i, \psi_{i}\left(z_{i}\right) \geq 0\right\} .
$$

Az $y_{i}\left(x_{-i}\right)$ tehát az $i$ játékos legkisebb nyeró értékelése.

A $Q_{i}$ definíciója szerint, a többi játékos rögzített $x_{-i} \in \Xi_{-i}$ értékelései mellett

$$
Q_{i}\left(z, x_{-i}\right)= \begin{cases}1, & \text { ha } z>y_{i}\left(x_{-i}\right) \\ \frac{1}{k}, & \text { ha } z=y_{i}\left(x_{-i}\right) \\ 0, & \text { ha } z<y_{i}\left(x_{-i}\right)\end{cases}
$$

Így persze

$$
\int_{0}^{x_{i}} Q_{i}\left(z, x_{-i}\right) d z= \begin{cases}x_{i}-y_{i}\left(x_{-i}\right), & \text { ha } x_{i}>y_{i}\left(x_{-i}\right) \\ 0, & \text { egyébként }\end{cases}
$$

ebből pedig

$$
M_{i}(x)=Q_{i}(x) x_{i}-\int_{0}^{x_{i}} Q_{i}\left(z, x_{-i}\right) d z= \begin{cases}x_{i}-\left(x_{i}-y_{i}\left(x_{-i}\right)\right), & \text { ha } x_{i}>y_{i}\left(x_{-i}\right), \\ \frac{1}{k} y_{i}\left(x_{-i}\right), & \text { ha } x_{i}=y_{i}\left(x_{-i}\right), \\ 0, & \text { ha } x_{i}<y_{i}\left(x_{-i}\right) .\end{cases}
$$

Összegezve elmondhatjuk tehát, hogy

$$
M_{i}(x)=Q_{i}(x) y_{i}\left(x_{-i}\right) .
$$

Ennek már nyilvánvaló interpretációja adható. Az $i$ játékos befizetési szabálya a játékos nyerési valószínúségének és annak az értékelésének a szorzata, amellyel még éppen nyerte volna az aukciót. 
Egy újabb pillanatra térjünk vissza a szimmetrikus esetre. Ekkor $y_{i}\left(x_{-i}\right)$ definíciójában $\psi_{i}\left(z_{i}\right) \geq \psi_{j}\left(x_{j}\right)$ pontosan akkor áll fenn, ha $\psi\left(z_{i}\right) \geq \psi\left(x_{j}\right)$, ami $z_{i} \geq x_{j}$ fennállásával ekvivalens. Ha $r=\psi^{-1}(0)$, akkor a regularitási feltevés miatt $\psi\left(z_{i}\right) \geq 0$ pontosan akkor igaz, ha $z \geq r$. Emiatt

$$
y_{i}\left(x_{-i}\right)=\min \left\{z_{i} \in[0, \omega]: z \geq x_{j} \forall j \neq i, z_{i} \geq r\right\}=\max \left\{x_{j}: j \neq i\right\} \vee r .
$$

Látható tehát, hogy ez egy másodáras aukció az $r=\psi^{-1}(0)$ optimális rezervációs árral. A 11.7 állításnak persze szép és egyszerú interpretációját adhatjuk a nem szimmetrikus eset mellett is. Az

$$
E(R)=E\left(\max \left\{\psi_{1}\left(X_{1}\right), \psi_{2}\left(X_{2}\right), \ldots, \psi_{N}\left(X_{N}\right), 0\right\}\right)
$$

formula azt jelenti, hogy az optimális megvalósítható mechanizmus a kikiáltó számára ugyanaz, mintha minden játékos a $\psi_{i}$ virtuális értékelésével licitálna, és ilyen módon játszanának elsőáras aukciót, de egyénenként meghatározott $\psi_{i}^{-1}(0)$ rezervációs árral. Ebben a kikiáltó által elképzelt elsőáras aukcióban az $i$ játékos akkor nyer, ha az ő virtuális értékelése a legnagyobb, de legalább zérus. Ez a 4 fejezet fényében azt jelenti, hogy a kikiáltó minden játékosnak külön-külön azt a rezervációs árat ajánlja, amely rezervációs ár a kikiáltó maximális bevételét biztosítaná abban az esetben, ha a többi játékosnak is az adott játékossal azonos értékeloszlása lenne. Így minden játékos más és más rezervációs árral szembesülve licitál a virtuális értékelésével. Ebben az elképzelt aukcióban persze a kikiáltó várható bevételét a fenti [11.1] formula adja. 
12. VCG-MECHANIZMUS 

AZ ELŐZŐ FEJEZETBEN tárgyalt optimális megvalósítható mechanizmus hibája, hogy nem hatékony abban az értelemben, hogy nem feltétlenül igaz, hogy a tárgyat elnyerő licitáló értékelése lenne a legnagyobb a licitálók közt. Gondoljunk csak arra, hogy ez egy egyénileg meghatározott rezervációs árral játszott elsőáras aukciónak feleltethető meg.

A 7 fejezetben azt láttuk, hogy még rezervációs ár nélküli esetben is elóállhat a hatékonyság sérülése. Kiszámoltuk ugyanis, - emlékezzünk a 7.2 ábrára -, hogy amennyiben két licitálóval játszott elsőáras aukciót modellezünk, akkor már egyenletes eloszlások esetén is megjelenik ez a sérülés, feltéve, hogy a két játékos értékeloszlásának tartója nem azonos.

Az előző fejezetben talált optimális mechanizmust ezért nagyon durvának érezzük, ha a racionalitási szempontok közé be akarjuk emelni azon elvárásunkat, hogy az aukciót az a játékos nyerje, akinek legtöbbet ér az aukció tárgyának birtoklása. Ebben a fejezetben tovább szúkítjük azon mechanizmusok körét, amelyek közt keressük azt, amelyik a lehetô legnagyobb várható bevételt hozza a kikiáltó számára. Ezt a szúkítést a racionalitási elvárásaink újabb bővítésével tesszük meg.

Végül ki fog derülni, hogy nincs semmi új a nap alatt, a hatékonyságot is elvárva egy másodáras aukciót kell játszanunk a kikiáltó várható bevételének optimalizálásához.

\subsection{Hatékony allokáció}

A VCG-mechanizmus definíciójának megértéséhez fontos a következő feladat. Jelölje $\langle\lambda, x\rangle$ az $x, \lambda \in \mathbb{R}^{N}$ vektorok belső szorzatát és $\Lambda$ a valószínúség eloszlások halmazát, azaz $\Lambda=\left\{\left(\lambda_{1}, \cdots, \lambda_{N}\right) \in[0,1]^{N}: \sum_{j=1}^{N} \lambda_{j} \leq 1\right\}$. Rögzített $x=\left(x_{1}, \cdots, x_{N}\right) \in \mathbb{R}^{N}$ értékelésvektor mellett keressük az $\langle\cdot, x\rangle$ függvény $\Lambda$ feletti maximumát. Formálisabban:

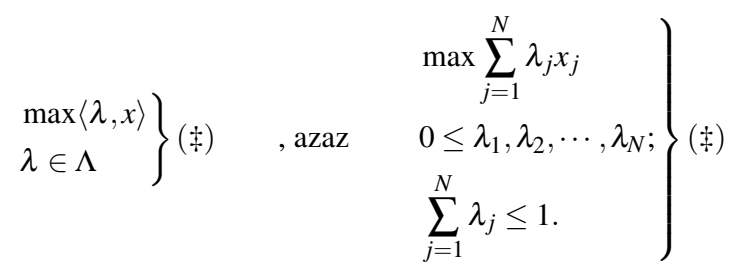

Látnunk kell, hogy mi a $\langle\cdot, x\rangle: \Lambda \rightarrow \mathbb{R}$ célfüggvény optimális értéke a $\Lambda$ halmaz felett, és hogy pontosan mely $\lambda \in \Lambda$ vektorokra vétetik fel az optimum.

Nézzük először a célfüggvény optimális értékét. Legyen tehát $x=\left(x_{1}, \cdots, x_{N}\right)$ rögzítve.

a) Ha minden $i=1, \cdots, N$ mellett $x_{i} \leq 0$, akkor minden $\lambda \in \Lambda, \lambda=\left(\lambda_{1}, \cdots, \lambda_{N}\right)$ esetén $\sum_{j=1}^{N} \lambda_{j} x_{j} \leq 0$, de ha például $\lambda=(0, \cdots, 0)$-t választjuk, akkor $\langle\lambda, x\rangle=0$ lesz. A célfüggvény optimális értéke tehát 0 . 
b) Tekintsük most azt az esetet, amikor van olyan $1 \leq i \leq N$, amelyre $x_{i}>0$. Ekkor minden $\lambda=\left(\lambda_{1}, \cdots, \lambda_{N}\right) \in \Lambda$ mellett

$$
\begin{aligned}
\sum_{j=1}^{N} \lambda_{j} x_{j} \leq \sum_{j=1}^{N} \lambda_{j} \max \left\{x_{1}, \cdots, x_{N}\right\}=\max \left\{x_{1}, \cdots, x_{N}\right\} & \sum_{j=1}^{N} \lambda_{j} \\
& \leq \max \left\{x_{1}, \cdots, x_{N}\right\} .
\end{aligned}
$$

Tegyük fel, hogy éppen $r$ darab maximális koordinátája van $x$-nek. Ekkor

$$
\max \left\{x_{1}, \cdots, x_{N}\right\}=x_{i_{1}}=x_{i_{2}}=\cdots=x_{i_{r}} .
$$

Válasszuk a $\lambda_{i_{1}}, \cdots, \lambda_{i_{r}}$ nem negatív számokat úgy, hogy $\sum_{k=1}^{r} \lambda_{i_{k}}=1$ legyen. A többi $j$ indexre legyen $\lambda_{j}=0$. Így

$$
\sum_{j=1}^{N} \lambda_{j} x_{j}=\sum_{k=1}^{r} \lambda_{i_{k}} x_{i_{k}}=\sum_{k=1}^{r} \lambda_{i_{k}} \max \left\{x_{1}, \cdots, x_{N}\right\}=\max \left\{x_{1}, \cdots, x_{N}\right\} .
$$

A fenti a) és b) esetet összegezve azt kapjuk, hogy a ( $\ddagger)$ feladatnak tetszőleges $x \in$ $\mathbb{R}^{N}$ mellett van megoldása, és ha adott $x$-re $W(x)$ jelöli a $(\ddagger)$ feladat célfüggvényének optimális értékét, azaz

$$
W(x)=\max _{\lambda \in \Lambda}\langle\lambda, x\rangle
$$

akkor 1

$$
W(x)=\max \left\{x_{1}, \cdots, x_{N}, 0\right\}=\max \{x, 0\} .
$$

Most térjünk rá annak vizsgálatára, hogy adott $x$ értékelésvektor mellett pontosan milyen eloszlások szolgáltatják a célfüggvény optimumát. Így a kérdés az, hogy ha $\lambda \in \Lambda, \lambda \in \arg \max _{\mu \in \Lambda}\langle\mu, x\rangle$, ergo ha

$$
\langle\lambda, x\rangle=W(x)=\max \{x, 0\},
$$

akkor $\lambda$ milyen alakú lehet.

Először is azt vegyük észre, optimális $\lambda=\left(\lambda_{1}, \cdots, \lambda_{N}\right)$ esetén, ha $x_{i}<0$, akkor erre az $i$ indexre $\lambda_{i}=0$-nak kell teljesülnie. Ugyanis, ha $\lambda_{i}>0$ lenne, akkor

$$
\lambda_{i} x_{i}<0 x_{i}
$$

és a $\lambda=\left(\lambda_{1}, \cdots, \lambda_{i}, \cdots, \lambda_{N}\right)$ eloszlást az $i$-edik koordinátájában nullázva is eloszlást kapunk. Márpedig ezen megváltoztatott $\left(\lambda_{1}, \cdots, 0, \cdots, \lambda_{N}\right)$ eloszlással a célfüggvény értéke szigorúan nagyobb, mint az eredeti $\lambda$ eloszlással.

Három esetet különböztetünk meg:

\footnotetext{
${ }^{1}$ Az egyszerúbb jelölés kedvéért a továbbiakban $x=\left(x_{1}, \cdots, x_{N}\right)$ mellett $\max \{x, 0\}=\max \left\{x_{1}, \cdots, x_{N}, 0\right\}$.
} 
a) Ha $x=(0, \cdots, 0)$ a nullvektor, akkor triviálisan minden $\lambda \in \Lambda$ megfelel, hiszen

$$
W(x)=\max \{x, 0\}=0=\langle\lambda, x\rangle \quad \forall \lambda \in \Lambda .
$$

b) Ha minden $j=1, \cdots, N$ koordinátára $x_{j} \leq 0$, de van olyan $i$, amelyre $x_{i}<0$. Ekkor optimális $\lambda$ mellett csak $\lambda_{i}=0$ lehetséges, ha viszont $x_{j}=0$, akkor $\lambda_{j}$-re semmilyen megkötésünk nincs. Az optimális $\lambda=\left(\lambda_{1}, \cdots, \lambda_{N}\right)$ tehát olyan, hogy azon $i$ indexekre, amelyekre $x_{i}<0 \lambda_{i}=0$, a többi indexre pedig csak annak kell teljesülnie, hogy az összeg 1-nél több ne legyen.

c) Az az eset maradt, mikor van olyan $i$ index, hogy $x_{i}>0$. Tegyük fel, hogy $\lambda \in$ $\arg \max _{\mu \in \Lambda}\langle\mu, x\rangle$. Ekkor

$$
W(x)=\max \{x, 0\}=\max \{x\}=\sum_{j=1}^{N} \lambda_{j} x_{j} \leq \max \{x\} \sum_{j=1}^{N} \lambda_{j} \leq \max \{x\} .
$$

A fenti sorban emiatt mindenütt egyenlőség van. Az utolsóra ez persze csak úgy lehetséges, hogy $\sum_{j=1}^{N} \lambda_{j}=1$. Na most:

i) Ha valamely $j$ mellett $x_{j}<0$, akkor $\lambda_{j}=0$.

ii) Ha valamely $j$ mellett $0 \leq x_{j}<\max \{x\}=x_{t}$, akkor $\lambda_{j}>0$ mellett

$$
\lambda_{j} x_{j}+\lambda_{t} x_{t}<\lambda_{j} x_{t}+\lambda_{t} x_{t}=\left(\lambda_{j}+\lambda_{t}\right) x_{t} .
$$

Így a $\left(\cdots, \lambda_{j}, \cdots, \lambda_{t}, \cdots\right)$ eloszlást átrendezve a $\left(\cdots, 0, \cdots, \lambda_{j}+\lambda_{t}, \cdots\right)$ eloszlássá a célfüggvény értéke nő, ergo $\langle\lambda, x\rangle$ csak úgy lehet optimális, ha $\lambda_{j}=0$.

Az i) és ii) esetek szerint optimális $\lambda$-ra tetszőleges

$$
x_{j}<\max \{x\} \text { esetén } \lambda_{j}=0 .
$$

Ha tehát pontosan $r$ darab koordinátában van maximuma $x$-nek, azaz

$$
0<\max \{x\}=x_{i_{1}}=x_{i_{2}}=\cdots=x_{i_{r}},
$$

akkor

$$
\sum_{k=1}^{r} \lambda_{i_{k}}=1 \text { és } \lambda_{j}=0 \text { egyébként }
$$

egy optimális $\lambda=\left(\lambda_{1}, \cdots, \lambda_{N}\right) \in \Lambda$ mellett.

Az alábbi állítást gondoltuk meg.

12.1. állítás. Adott $x \in \mathbb{R}^{N}$ mellett tekintsük a $\ddagger$ feladatot.

$$
\left.\begin{array}{l}
\max \langle\lambda, x\rangle \\
\lambda \in \Lambda .
\end{array}\right\}(\ddagger)
$$

Adott x mellett jelölje $W(x)$ az $\langle\cdot, x\rangle: \Lambda \rightarrow \mathbb{R}$ célfüggvény optimális értékét. 
1. Ekkor

$$
W(x)=\max \{x, 0\},
$$

2. A $\lambda \in \Lambda$ eloszlásra $\max \{x, 0\}=\langle\lambda, x\rangle$ akkor és csak akkor, ha

a) $\max \{x\} \leq 0$ esetén azon $j$ indexekre, amelyre $x_{j}<W(x)=0$ a $\lambda_{j}=0$, ha pedig az $i_{1}, i_{2}, \cdots, i_{r}$ indexekre

$$
x_{i_{1}}=x_{i_{2}}=, \cdots,=x_{i_{r}}=0=W(x),
$$

akkor a $\lambda_{i_{1}}, \cdots, \lambda_{i_{r}} \in[0,1]$ számok tetszólegesek lehetnek avval a feltétellel, hogy

$$
\sum_{k=1}^{r} \lambda_{i_{k}} \leq 1
$$

b) $\max \{x\}>0$ esetén azon $j$ indexekre, amelyekre $x_{j}<W(x)=\max \{x\} a$ $\lambda_{j}=0$, ha pedig az $i_{1}, i_{2}, \cdots, i_{r}$ indexekre

$$
x_{i_{1}}=x_{i_{2}}=, \cdots,=x_{i_{r}}=\max \{x\}=W(x),
$$

akkor a $\lambda_{i_{1}}, \cdots, \lambda_{i_{r}} \in[0,1]$ számok tetszólegesek lehetnek avval a feltétellel, hogy

$$
\sum_{k=1}^{r} \lambda_{i_{k}}=1
$$

A továbbiakban annyiban módosítjuk a 9.1 szakaszban definiált modellt, hogy a licitálók eloszlásainak tartója kicsit általánosabb. Innen azt tesszük fel, hogy az $i$-edik licitáló értékelését kifejező eloszlás tartója az $\left[\alpha_{i}, \omega_{i}\right]$ intervallum. Itt $\alpha_{i}<0$ is lehetséges.

12.2. definíció (jóléti függvény, hatékony allokáció). A $Q^{\star}: \Xi \rightarrow \Lambda$ allokáció hatékony, ha minden $x \in \Xi$ értékelésvektor esetén

$$
Q^{\star}(x) \in \underset{\mu \in \Lambda}{\arg \max }\langle\mu, x\rangle .
$$

Definiálja $W: \Xi \rightarrow \mathbb{R}$ a jóléti függvényt:

$$
W(x)=\max \left\{\sum_{j=1}^{N} \lambda_{j} x_{j}: \lambda=\left(\lambda_{1}, \cdots, \lambda_{N}\right) \in \Lambda\right\} .
$$

A világos intuíció szerint $W(x)$ fejezi ki az $x$ értékelésú licitálók maximális összhasznosságát. A definíció és a (†) feladatra adott válasz szerint

$$
W(x)=\max \{x, 0\}=\sum_{j=1}^{N} Q_{j}^{\star}(x) x_{j} .
$$


12.3. definíció. Jelölje valamely $i$ licitáló esetén $W_{-i}(x)$ a nem $i$ licitálók hasznosság maximumát:

$$
W_{-i}(x)=\sum_{\substack{j=1 \\ j \neq i}}^{N} Q_{j}^{\star}(x) x_{j}=W(x)-Q_{i}^{\star}(x) x_{i}
$$

\subsection{A vCG-mechanizmus optimalitása}

Most a VCG-befizetési szabály definíciója következik.

12.4. definíció (VCG-befizetési szabály). Adott $Q^{\star}: \Xi \rightarrow \Lambda$ hatékony allokáció esetén definiálja minden $i=1, \cdots, N$ mellett

$$
M_{i}^{V}(x)=W\left(\alpha_{i}, x_{-i}\right)-W_{-i}(x)
$$

a VCG-befizetési szabályt.

Persze elsô célunk, hogy belássuk egy $\left(Q^{\star}, M^{V}\right)$ vCG-direkt-mechanizmus ösztönző voltát. Ehhez van szükségünk a $z_{i} \mapsto Q_{i}^{\star}\left(z_{i}, x_{-i}\right) x_{i}-M_{i}^{V}\left(z_{i}, x_{-i}\right)$ függvény vizsgálatára. E függvény három legfontosabb tulajdonságát foglaljuk össze a következő lemmában.

12.5. lemma. Rögzített $x \in \Xi$ értékelésvektor és rögzített $i=1, \cdots, N$ mellett

1. Fennáll az,

$$
Q_{i}^{\star}\left(z_{i}, x_{-i}\right) x_{i}-M_{i}^{V}\left(z_{i}, x_{-i}\right)=\left\langle Q^{\star}\left(z_{i}, x_{-i}\right), x\right\rangle-W\left(\alpha_{i}, x_{-i}\right)
$$

azonosság;

2. Az alábbi $\left[\alpha_{i}, \omega_{i}\right] \rightarrow \mathbb{R}$

$$
z_{i} \mapsto Q_{i}^{\star}\left(z_{i}, x_{-i}\right) x_{i}-M_{i}^{V}\left(z_{i}, x_{-i}\right)
$$

függvény $z_{i}=x_{i}$ pontban maximális;

3. Teljesül a lenti azonosság és nemnegativitás

$$
Q_{i}^{\star}(x) x_{i}-M_{i}^{V}(x)=W(x)-W\left(\alpha_{i}, x_{-i}\right) \geq 0 .
$$

Bizonyítás. Egyszerú átalakításokkal

$$
Q_{i}^{\star}\left(z_{i}, x_{-i}\right) x_{i}-M_{i}^{V}\left(z_{i}, x_{-i}\right)=Q_{i}^{\star}\left(z_{i}, x_{-i}\right) x_{i}+W_{-i}\left(z_{i}, x_{-i}\right)-W\left(\alpha_{i}, x_{-i}\right) .
$$

A jobb oldali elsô két tagot tovább írva:

$$
Q_{i}^{\star}\left(z_{i}, x_{-i}\right) x_{i}+W_{-i}\left(z_{i}, x_{-i}\right)=\sum_{\substack{j=1 \\ i \neq j}}^{N} Q_{j}^{\star}\left(z_{i}, x_{-i}\right) x_{j}+Q_{i}^{\star}\left(z_{i}, x_{-i}\right) x_{i}=\left\langle Q^{\star}\left(z_{i}, x_{-i}\right), x\right\rangle,
$$

tehát az első pont indoklásával készen is vagyunk. 
Most tekintsünk a $\left\langle Q^{\star}\left(z_{i}, x_{-i}\right), x\right\rangle$ számra. Ez a kifejezés a $(\ddagger)$ feladat $\langle\cdot, x\rangle$ célfüggvényének valamely $\Lambda$ pontbeli értéke. No de $Q^{\star}(x)$ definíciója pont az, hogy olyan $\Lambda$-beli eloszlásvektor, ahol e célfüggvény maximális, ergo

$$
\left\langle Q^{\star}\left(z_{i}, x_{-i}\right), x\right\rangle \leq\left\langle Q^{\star}(x), x\right\rangle=\left\langle Q^{\star}\left(x_{i}, x_{-i}\right), x\right\rangle .
$$

Ezt úgy is mondhatjuk, hogy a $\left\langle Q^{\star}\left(\cdot, x_{-i}\right), x\right\rangle$ függvény az értelmezési tartománya $x_{i}$ pontjában maximumát veszi fel. A már igazolt állítás szerint a szóban forgó

$$
z_{i} \mapsto Q_{i}^{\star}\left(z_{i}, x_{-i}\right) x_{i}-M_{i}^{V}\left(z_{i}, x_{-i}\right)
$$

függvény a $\left\langle Q^{\star}\left(\cdot, x_{-i}\right), x\right\rangle$ függvénytől csak egy a $z_{i}$ változótól független konstansban különbözik, ergo ez a függvény is felveszi $x_{i}$-ben a legnagyobb értékét.

Az utolsó állítás egyenlősége nyilvánvaló következménye az elsőnek, ha $z_{i}=x_{i}$ helyettesítésre gondolunk:

$$
\begin{gathered}
Q_{i}^{\star}(x) x_{i}-M_{i}^{V}(x)=Q_{i}^{\star}\left(x_{i}, x_{-i}\right) x_{i}-M_{i}^{V}\left(x_{i}, x_{-i}\right)= \\
\left\langle Q^{\star}\left(x_{i}, x_{-i}\right), x\right\rangle-W\left(\alpha_{i}, x_{-i}\right)=\left\langle Q^{\star}(x), x\right\rangle-W\left(\alpha_{i}, x_{-i}\right)= \\
W(x)-W\left(\alpha_{i}, x_{-i}\right) .
\end{gathered}
$$

Persze tudjuk azt is, hogy $W(x)=\max \{x, 0\}$. Ez utóbbi függvény nyilván monoton növő függvénye az $x_{i}$ változónak, ergo $\alpha_{i} \leq x_{i}$ szerint $W\left(x_{i}, x_{-i}\right) \geq W\left(\alpha_{i}, x_{-i}\right)$.

12.6. állítás. Legyen $Q^{\star}: \Xi \rightarrow \Lambda$ hatékony allokáció, és $M^{V}: \Xi \rightarrow \mathbb{R}^{N}$ egy VCGbefizetési függvény. Ekkor a $\left(Q^{\star}, M^{V}\right)$ VCG-mechanizmus egy

1. ösztönzó és egyénileg racionális, azaz megvalósítható direkt-mechanizmus;

2. olyan mechanizmus, amely által generált valamennyi várható egyensúlyi hasznosság eltûnik az egyes játékosok minimális értékelése mellett.

Formálisabban: Minden $i=1, \cdots, N$ licitálóra

$$
U_{i}\left(\alpha_{i}\right)=q_{i}\left(\alpha_{i}\right) \alpha_{i}-m_{i}\left(\alpha_{i}\right)=0
$$

Bizonyítás. Az ösztönző mechanizmus definíciója szerint azt kell látnunk, hogy a

$$
z_{i} \mapsto q_{i}\left(z_{i}\right) x_{i}-m_{i}\left(z_{i}\right)=E\left(Q_{i}^{\star}\left(z_{i}, X_{-i}\right)\right) x_{i}-E\left(M_{i}^{V}\left(z_{i}, X_{-i}\right)\right)
$$

függvény minden rögzített $x \in \Xi$ értékelés és minden $i=1, \cdots, N$ licitáló mellett a $z_{i}=x_{i}$ pontban maximális. Az előző lemma második pontjában lévő függvénybe komponálva az $N-1$ koordinátából álló $X_{-i}=\left(X_{1}, \cdots, X_{i-1}, X_{i+1}, \cdots, X_{N}\right)$ valószínúségi vektorváltozót azt kapjuk, hogy a minden egyes $z_{i} \in\left[\alpha_{i}, \omega_{i}\right]$ mellett

$$
Q_{i}^{\star}\left(z_{i}, X_{-i}\right) x_{i}-M^{V}\left(z_{i}, X_{-i}\right) \leq Q_{i}^{\star}\left(x_{i}, X_{-i}\right) x_{i}-M^{V}\left(x_{i}, X_{-i}\right)
$$


az $X_{-i}$ minden kiértékelése mellett. Így a várható érték monotonitása miatt

$$
\begin{array}{r}
q_{i}\left(z_{i}\right) x_{i}-m_{i}\left(z_{i}\right)= \\
E\left(Q_{i}^{\star}\left(z_{i}, X_{-i}\right)\right) x_{i}-E\left(M_{i}^{V}\left(z_{i}, X_{-i}\right)\right)=E\left(Q_{i}^{\star}\left(z_{i}, X_{-i}\right) x_{i}-M_{i}^{V}\left(z_{i}, X_{-i}\right)\right) \leq \\
E\left(Q_{i}^{\star}\left(x_{i}, X_{-i}\right) x_{i}-M_{i}^{V}\left(x_{i}, X_{-i}\right)\right)=E\left(Q_{i}^{\star}\left(x_{i}, X_{-i}\right)\right) x_{i}-E\left(M_{i}^{V}\left(x_{i}, X_{-i}\right)\right)= \\
q_{i}\left(x_{i}\right) x_{i}-m_{i}\left(x_{i}\right),
\end{array}
$$

ami éppen azt jelenti, hogy a szóban forgó VCG-mechanizmus ösztönző.

Az egyéni racionalitáshoz az kell, hogy az $U_{i}^{V}\left(x_{i}\right)=q_{i}\left(x_{i}\right) x_{i}-m_{i}\left(x_{i}\right)$ egyéni hasznosságok nem negatívak legyenek. Ehhez az elózőhöz hasonlóan, de most a lemma harmadik pontjára koncentrálva azt kapjuk, hogy

$$
U_{i}^{V}\left(x_{i}\right)=E\left(Q_{i}^{\star}\left(x_{i}, X_{-i}\right) x_{i}-M_{i}^{V}\left(x_{i}, X_{-i}\right)\right)=E\left(W\left(x_{i}, X_{-i}\right)-W\left(\alpha_{i}, X_{-i}\right)\right) .
$$

Persze minden egyes $i$ és akármilyen $x_{i} \in\left[\alpha_{i}, \omega_{i}\right]$ mellett a

$$
W\left(x_{i}, X_{-i}\right)-W\left(\alpha_{i}, X_{-i}\right)
$$

egy nem negatív valószínúségi vektorváltozó, ezért ennek a várható értéke is nem negatív.

Mivel a konstans zérus függvény várható értéke is nulla, ezért azt is látjuk, hogy a licitálók egyéni várható hasznosságai valóban nullává válnak a tartó $\alpha_{i}$ baloldali végpontjában.

12.7. állítás. Legyen $Q^{\star}: \Xi \rightarrow \Lambda$ hatékony allokáció, és $M^{V}: \Xi \rightarrow \mathbb{R}^{N}$ egy VCGbefizetési függvény. Láttuk, hogy $\left(Q^{\star}, M^{V}\right)$ megvalósitható. Most legyen $M: \Xi \rightarrow \mathbb{R}^{N}$ egy másik befizetési függvény, amellyel a $\left(Q^{\star}, M\right)$ megvalósítható direkt-mechanizmus. Jelölje $U_{i}^{V}$ és $m_{i}^{V}$ a VCG-mechanizmus várható hasznosságát és várható befizetését, hasonlóan $U_{i}$ és $m_{i}$ a másik mechanizmus várható hasznosságát és várható befizetését. Ekkor

- Minden $i=1, \cdots, N$ licitálóra és minden $x_{i} \in\left[\alpha_{i}, \omega_{i}\right]$ értékelésre

$$
U_{i}\left(x_{i}\right)-U_{i}^{V}\left(x_{i}\right)=U_{i}\left(\alpha_{i}\right) \geq 0,
$$

- Minden $i=1, \cdots, N$ licitálóra és minden $x_{i} \in\left[\alpha_{i}, \omega_{i}\right]$ értékelésre

$$
m_{i}^{V}\left(x_{i}\right)-m_{i}\left(x_{i}\right)=U_{i}\left(\alpha_{i}\right) \geq 0
$$


Bizonyítás. Mivel mindkét mechanizmus ösztönző, ezért az ösztönző mechanizmusok 10.4 állításban megfogalmazott karakterizációja szerint

$$
\begin{aligned}
U_{i}\left(x_{i}\right) & =U_{i}\left(\alpha_{i}\right)+\int_{\alpha_{i}}^{x_{i}} q_{i}(t) d t \\
U_{i}^{V}\left(x_{i}\right) & =U_{i}^{V}\left(\alpha_{i}\right)+\int_{\alpha_{i}}^{x_{i}} q_{i}(t) d t,
\end{aligned}
$$

ahol $q_{i}(t)=E\left(Q^{\star}\left(t, X_{-i}\right)\right)$. Az imént láttuk, hogy a VCG-mechanizmus generálta hasznosságok a bal végpontban eltûnnek, azaz $U_{i}^{V}\left(\alpha_{i}\right)=0$ minden licitáló mellett, így $U_{i}\left(x_{i}\right)=U_{i}\left(\alpha_{i}\right)+U_{i}^{V}\left(x_{i}\right)$. Ebből már látszik is, hogy minden $x_{i} \in\left[\alpha_{i}, \omega_{i}\right]$ mellett

$$
U_{i}\left(x_{i}\right)-U_{i}^{V}\left(x_{i}\right)=U_{i}\left(\alpha_{i}\right) \geq 0,
$$

hiszen $\left(Q^{\star}, M\right)$ is egyénileg racionális.

Az egyensúlyi hasznosságokra definíció szerint

$$
\begin{aligned}
U_{i}\left(x_{i}\right) & =x_{i} q_{i}\left(x_{i}\right)-m_{i}\left(x_{i}\right) \\
U_{i}^{V}\left(x_{i}\right) & =x_{i} q_{i}\left(x_{i}\right)-m_{i}^{V}\left(x_{i}\right) .
\end{aligned}
$$

A felső egyenletből az alsót kivonva kapjuk, hogy

$$
m_{i}^{V}\left(x_{i}\right)-m_{i}\left(x_{i}\right)=U_{i}\left(x_{i}\right)-U_{i}^{V}\left(x_{i}\right)=U_{i}\left(\alpha_{i}\right) \geq 0 .
$$

Ezt kellett belátni.

Meggondoltuk tehát, hogy adott $Q^{\star}$ hatékony allokációval tetszőleges olyan $M$ befizetési szabályra, amelyre $\left(Q^{\star}, M\right)$ megvalósítható a kapott várható egyensúlyi hasznosság függvények csak konstansban különböznek egymástól. Ezen várható egyensúlyi hasznosságok közt a VCG- mechanizmusé a legkisebb.

Hasonlóan, a várható befizetési függvények is egymás eltoltjai, méghozzá ugyanavval a konstanssal. Ezen várható befizetések közt a VCG-hez tartozó a lehető legnagyobb. Az is adódik még, hogy

$$
m_{i}^{V}\left(\alpha_{i}\right)=\alpha_{i} q_{i}\left(\alpha_{i}\right)
$$

A fejezet legfontosabb eredményéhez érkeztünk:

12.8. állítás. Adott hatékony allokáció mellett a VCG-mechanizmus garantálja a kikiáltó legnagyobb várható bevételét az adott hatékony allokációhoz található összes ösztönzố és egyénileg racionális, azaz az összes megvalósítható mechanizmusok közül.

Bizonyítás. Adott $Q^{\star}$ hatékony allokációhoz legyen $\left(Q^{\star}, M^{V}\right)$ a VCG-mechanizmus, és $\left(Q^{\star}, M\right)$ valamely megvalósítható mechanizmus. Jelölje, mint korábban $m_{i}^{V}$ a VCG-hez 
tartozó, és $m_{i}$ a másikhoz tartozó várható befizetéseket. A kikiáltó bevétele a licitáló befizetéseiből és csak abból keletkezik. E várható árbevétel tehát a

$$
\sum_{j=1}^{N} m_{j}\left(X_{j}\right) \quad \text { és } \quad \sum_{j=1}^{N} m_{j}^{V}\left(X_{j}\right)
$$

valószínúségi változók összegének várható értékei. Jelölje $E\left(R^{V}\right)$ a kikiáltónak a VCGhez tartozó várható bevételét, és $E(R)$ a másik mechanizmus esetén adódó várható bevételt. Ekkor

$$
\begin{aligned}
& E(R)= \\
& E\left(\sum_{j=1}^{N} m_{j}\left(X_{j}\right)\right)=\sum_{j=1}^{N} E\left(m_{j}\left(X_{j}\right)\right) \leq \sum_{j=1}^{N} E\left(m_{j}^{V}\left(X_{j}\right)\right)=E\left(\sum_{j=1}^{N} m_{j}^{V}\left(X_{j}\right)\right)= \\
& E\left(R^{V}\right) .
\end{aligned}
$$

Ezt kellett belátni.

\subsection{A vCG-befizetési szabály értelmezése}

Miután megértettük, hogy a VCG-mechanizmus az optimális, ha a kikiáltó várható bevételét maximalizáljuk a megvalósítható és hatékony mechanizmusok közt, felmerül a kérdés, hogy nem túl trükkösen definiáltuk-e az $M^{V}$ kifizetéseket. Jó lenne látni, hogy honnan jön a gondolat, hogy éppen

$$
M_{i}^{V}(x)=W\left(\alpha_{i}, x_{-i}\right)-W_{-i}(x)
$$

módon kell definiálni a mechanizmus befizetését. A fejezet hátralévő részében erre szeretnénk választ keresni.

Egy kicsit egyszerúbb esetet vizsgálunk avval, hogy a további feltevésünk szerint minden licitáló értékelésének bal végpontja zérus, azaz $\alpha_{i}=0$, minden $i=1, \cdots, N$ mellett.

Tekintsünk egy $x \in \Xi$ értékelést.

1. A legegyszerúbb eset, mikor $x$-ben csak egyetlen legnagyobb koordináta van. Ha ez az $i$-edik, akkor a fejezet elsô szakaszában megértett hatékony allokáció szabályai szerint

$$
Q_{i}^{\star}(x)=1, \quad \text { és minden más } j \neq i \text {-re } \quad Q_{j}^{\star}(x)=0 \text {. }
$$


Persze ekkor

$$
\begin{aligned}
W\left(0, x_{-i}\right) & =\max \left\{x_{-i}\right\}=\max 2\{x\}, \\
W_{-i}(x) & =\sum_{\substack{j=1 \\
j \neq i}}^{N} Q_{j}^{\star}(x) x_{j}=0 .
\end{aligned}
$$

Így a győztes $i$ licitáló befizetése $M_{i}^{V}(x)=\max 2\{x\}$.

Most nézzük a vesztesek befizetését, azaz $j \neq i$. Ekkor

$$
\begin{aligned}
W\left(0, x_{-j}\right) & =\max \left\{x_{k}: k \neq j\right\}=\max \{x\}, \\
W_{-j}(x) & =Q_{i}^{\star}(x) x_{i}=\max \{x\} .
\end{aligned}
$$

A vesztes befizetése tehát $M_{j}^{V}(x)=0$.

Ott tartunk tehát, hogy abban az esetben, amikor a licitálók között nincs holtverseny,

$$
M_{i}^{V}(x)=Q_{i}^{\star}(x) \cdot \max 2\{x\},
$$

minden $i=1, \cdots, N$ licitáló esetén.

2. Most tegyük fel, hogy pontosan $r$ licitáló közt van az élen nem zérus értékú holtverseny, azaz

$$
\max \{x\}=x_{i_{1}}=x_{i_{2}}=\cdots=x_{i_{r}}>0 .
$$

Tudjuk a $Q^{\star}$ allokáció hatékonysága miatt, hogy ekkor $\sum_{t=1}^{r} Q_{i_{t}}^{\star}(x)=1$, és a vesztes licitálók allokációjának valószínúsége zérus.

Legyen $j$ egy vesztes index, azaz $x_{j}<\max \{x\}$. Ekkor

$$
\begin{aligned}
W\left(0, x_{-j}\right) & =\max \{x\}, \\
W_{-j}(x) & =W(x)-Q_{j}^{\star}(x) x_{j}=\max \{x\} .
\end{aligned}
$$

A vesztes befizetése tehát most is $M_{j}^{V}(x)=0$.

Végül nézzük a győztesek befizetését, azaz a vizsgált licitáló indexe valamely $1 \leq t \leq r$ mellett $i_{t}$. Figyeljünk arra, hogy ekkor $x_{i_{t}}=\max \{x\}=\max 2\{x\}$, így

$$
\begin{aligned}
W\left(0, x_{-i_{t}}\right) & =x_{i_{r}}=\max \{x\}=\max 2\{x\}, \\
W_{-i_{t}}(x) & =W(x)-Q_{i_{t}}^{\star}(x) x_{i_{t}} \\
& =x_{i_{t}}-Q_{i_{t}}^{\star}(x) x_{i_{t}} \\
& =\left(1-Q_{i_{t}}^{\star}(x)\right) \max 2\{x\} .
\end{aligned}
$$

Így az $M_{i_{t}}^{V}(x)=\max 2\{x\}-\left(1-Q_{i_{t}}^{\star}(x)\right) \max 2\{x\}=Q_{i_{t}}^{\star}(x) \cdot \max 2\{x\}$ szabály adja meg a nyertes licitálók befizetési kötelezettségét.

Azt igazoltuk tehát, hogy a holtversenyes és a nem holtversenyes esetben is

$$
M_{i}^{V}(x)=Q_{i}^{\star}(x) \cdot \max 2\{x\}
$$

adja a befizetési szabályt. 


\section{4. Összegzés}

A VCG-mechanizmusra mint másodáras aukcióra kell gondolnunk úgy, hogy szembe nézünk az azonos értékelések lehetőségével is. A döntés előtt, de az értékelések megismerése után adott egy hatékony $\left\{\lambda_{1}, \cdots, \lambda_{N}\right\}$ allokáció. A vesztesek nem fizetnek semmit és nem kapnak semmit. A győztesek mindegyike befizeti az értékelésének, ergo a második legnagyobb értékelésnek az ő $\lambda_{i_{t}}$ nyerési valószínúségekkel súlyozott értékét. Persze a maximális értékelést adók közül csak az egyik kapja meg az aukció tárgyát, de ennek valószínúsége az ô befizetésével egyenesen arányos.

Az algoritmus tehát a kikiáltó szempontjából végtelen egyszerú: Ő mindenképpen a második legnagyobb értékelést kapja.

Fontos még látni, hogy több hatékony allokáció is létezik, de az azokkal képzett VCG-mechanizmusok egymással egyenértékúek abban az értelemben, hogy a kikiáltó számára ugyanakkora várható árbevétellel járnak. Ha így van, akkor persze magától értetődik a legtermészetesebb előtérbe helyezése: Ha $k$ darab $k \geq 1$ maximális értékelés van, akkor a maximális értékelésúek közt mindenki azonos $\frac{1}{k}$ valószínúséggel nyeri az aukció tárgyát, míg a többiek 0 valószínúséggel nyerik azt. A veszteseknek nincs befizetési kötelezettsége, és a nyertesek, attól függetlenül, hogy végül hozzájutnak a tárgyhoz vagy sem, befizetik a rájuk eső

$$
\frac{1}{k} \cdot \max 2\{x\}
$$

összeget, majd a $k$ nyertes közt valamilyen azonos nyerési valószínûségû szétlövést rendeznek. 

Függelék 



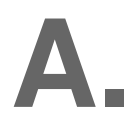

VALÓS KONVEX FÜGGVÉNYEK 



\section{A.1. Konvexitás és integrálfüggvény}

A.1. definíció (konvex függvény). Legyen $I$ egy intervallum. Az $f: I \rightarrow \mathbb{R}$ függvényt konvexnek nevezzük, ha minden $x, y \in I, x<y$, és minden $\lambda \in[0,1]$ mellett

$$
f(\lambda x+(1-\lambda) y) \leq \lambda f(x)+(1-\lambda) f(y) .
$$

Az $f$ függvényt szigorúan konvexnek mondjuk, ha minden $\lambda \in(0,1)$ esetén

$$
f(\lambda x+(1-\lambda) y)<\lambda f(x)+(1-\lambda) f(y)
$$

is fennáll. Az $f$ függvény (szigorúan) konkáv, ha $-f$ (szigorúan) konvex.

A.2. megjegyzés. Könnyú számolással ellenőrizhetjük, hogy $x \leq c \leq y, x \neq y$ mellett

$$
c=\frac{y-c}{y-x} x+\frac{c-x}{y-x} y .
$$

Ezek szerint az $f$ függvény konvexitását a következőképpen is fogalmazhatjuk:

Az $f$ pontosan akkor konvex, ha minden $x \leq c \leq y, x \neq y$ esetén

$$
f(c) \leq \frac{y-c}{y-x} f(x)+\frac{c-x}{y-x} f(y) .
$$

A.3. állítás. Legyen $g: I \rightarrow \mathbb{R}$ egy intervallumon értelmezett (szigorúan) monoton növö függvény, $c \in$ I rögzített pont. Definiálja

$$
F(x)=\int_{c}^{x} g(t) d t
$$

a g integrálfüggvényét. Ekkor $F: I \rightarrow \mathbb{R}$ függvény (szigorúan) konvex.

Bizonyítás. Legyen $\lambda \in[0,1]$ és $x<y$, és $u=\lambda x+(1-\lambda) y$. Ekkor

$$
\begin{aligned}
\lambda F(x)+(1-\lambda) F(y)-F(u) & =\lambda(F(x)-F(u))+(1-\lambda)(F(y)-F(u)) \\
& =-\lambda \int_{x}^{u} g+(1-\lambda) \int_{u}^{y} g(t) d t .
\end{aligned}
$$

De $g$ (szigorúan) monoton növekedése miatt $\int_{u}^{y} g(t) d t \geq(y-u) g(u)\left(\int_{u}^{y} g(t) d t>(y-\right.$ $u) g(u))$ valamint $\int_{x}^{u} g \leq(u-x) g(u)\left(\int_{x}^{u} g<(u-x) g(u)\right)$. Így folytatva az elóző becslést azt kapjuk, hogy

$$
\begin{aligned}
\lambda F(x)+(1-\lambda) F(y)-F(u) & \geq(1-\lambda)(y-u) g(u)-\lambda(u-x) g(u) \\
& =g(u)(y-u-\lambda y+\lambda u-\lambda u+\lambda x) .
\end{aligned}
$$

Kiszámolva $g(u)$ fenti együtthatóját azt kapjuk, hogy

$$
y-u-\lambda y+\lambda x=y-\lambda x-(1-\lambda) y-\lambda y+\lambda x=y-\lambda x-y+\lambda y-\lambda y+\lambda x=0 .
$$

Azt bizonyítottuk tehát, hogy

$$
\lambda F(x)+(1-\lambda) F(y)-F(\lambda x+(1-\lambda y)) \geq 0 .
$$

Ezt kellett belátni. 
A.4. megjegyzés. Jelölje tetszőleges $f: I \rightarrow \mathbb{R}$ függvény és rögzített $c \in I$ mellett

$$
F_{c}(u)=\frac{f(u)-f(c)}{u-c}
$$

az $f$ függvény $c$ ponthoz tartozó különbségi hányados függvényét.

A.5. állítás (konvexitás és a különbségi hányados monotonitása). Legyen $f: I \rightarrow \mathbb{R}$ egy intervallumon értelmezett függvény. Az $f$ pontosan akkor (szigorúan) konvex, ha minden $c \in I$ esetén az $F_{c}$ különbségi hányados függvény (szigorúan) monoton nö.

Bizonyítás. Legyen $u<c<v$. Tekintsük az alább ekvivalens átalakításokat:

$$
\begin{aligned}
f(c) & \leq \frac{v-c}{v-u} f(u)+\frac{c-u}{v-u} f(v) \\
((v-c)+(c-u)) f(c) & \leq(v-c) f(u)+(c-u) f(v) \\
(v-c)(f(c)-f(u)) & \leq(c-u)(f(v)-f(c)) \\
F_{c}(u) & \leq F_{c}(v)
\end{aligned}
$$

Amennyiben $u<v<c$, akkor az alábbi ekvivalens átalakítások szükségesek:

$$
\begin{aligned}
f(v) & \leq \frac{c-v}{c-u} f(u)+\frac{v-u}{c-u} f(c) \\
(c-u) f(v) & \leq(c-v) f(u)+((c-u)-(c-v)) f(c) \\
(c-u)(f(v)-f(c)) & \leq(c-v)(f(u)-f(c)) \\
-F_{c}(v) & \leq-F_{c}(u) \\
F_{c}(v) & \geq F_{c}(u)
\end{aligned}
$$

A $c<u<v$ esetén pedig

$$
\begin{aligned}
f(u) & \leq \frac{v-u}{v-c} f(c)+\frac{u-c}{v-c} f(v) \\
(v-c) f(u) & \leq((v-c)-(u-c)) f(c)+(u-c) f(v) \\
(v-c)(f(u)-f(c)) & \leq(u-c)(f(v)-f(c)) \\
F_{c}(u) & \leq F_{c}(v)
\end{aligned}
$$

Világos, hogy mindhárom esetben az elsô egyenlőtlenség a konvexitás definíciója, amelyekkel $F_{c}(u) \leq F_{c}(v)$ ekvivalens. Ezt kellett belátni.

A.6. állítás (konvex függvény korlátossága). Legyen $f:[a, b] \rightarrow \mathbb{R}$ egy korlátos és zárt intervallumon értelmezett konvex függvény. Ekkor $f$ korlátos is.

Bizonyítás. Legyen $a<c<b$ tetszólegesen rögzítve. Tudjuk, hogy $F_{c}(a) \leq F_{c}(u) \leq$ $F_{c}(b)$ fennáll minden $u \in[a, b], u \neq c$ esetén. Ha például $F_{c}(u) \geq 0$, akkor 
$F_{c}(u) \leq F_{c}(b)=\left|F_{c}(b)\right|$, és ha $F_{c}(u)<0$, akkor $\left|F_{c}(u)\right| \leq\left|F_{c}(a)\right|$. Ebböl $L=$ $\max \left\{\left|F_{c}(a)\right|,\left|F_{c}(b)\right|\right\}$ bevezetésével $\left|F_{c}(u)\right| \leq L$ adódik. No de így

$$
|f(u)| \leq|f(u)-f(c)|+|f(c)| \leq L|u-c|+|f(c)| \leq L|b-a|+|f(c)|
$$

becslés teljesül már minden $u \in I$ esetén. Ezt kellett belátni.

A.7. állítás (konvex függvény folytonossága). Legyen $f: I \rightarrow \mathbb{R}$ egy intervallumon értelmezett konvex függvény. Ekkor az $f$ az I intervallum minden belső pontjában folytonos.

Bizonyítás. Legyen $a<x<b$, ahol $a, b \in I$. Megmutatjuk, hogy $f$ folytonos az $x$ pontban: Világos, hogy bevezetve a $K=\max \left\{\left|F_{x}(a)\right|,\left|F_{x}(b)\right|\right\}$ jelölést, tetszőleges $u \in(a, b)$ mellett $\left|F_{x}(u)\right| \leq K$, hiszen az $F_{x}$ különbségi hányados függvény monoton növő. Ekkor viszont minden $u \in(a, b)$ szám esetén $|f(u)-f(x)| \leq K|u-x|$, ezért $f$ valóban folytonos az $x$ pontban.

A.8. definíció (konvex függvény bal- és jobb oldali deriváltja). Legyen $x$ az $f$ konvex függvény $I$ értelmezési tartományának egy belsô pontja. Definiálja $f_{-}^{\prime}$ és $f_{+}^{\prime}$ a bal és jobb oldali derivált-függvényeket:

$$
\begin{aligned}
& f_{-}^{\prime}(x)=\sup \left\{\frac{f(y)-f(x)}{y-x}: y \in I, y<x\right\} \\
& f_{+}^{\prime}(x)=\inf \left\{\frac{f(y)-f(x)}{y-x}: y \in I, y>x\right\} .
\end{aligned}
$$

Világos, hogy az $F_{x}$ különbségi hányados függvény monotonitása, és mivel $x$ belsô pontja $f$ értelmezési tartományának, a szóban forgó szuprémum és infimum létezik és megegyezik a különbségi hányados függvény alábbi bal és jobb oldali határértékével.

$$
f_{-}^{\prime}(x)=\lim _{y \rightarrow x-} F_{x}(y) \text { valamint } f_{+}^{\prime}(x)=\lim _{y \rightarrow x+} F_{x}(y)
$$

A.9. állítás. Legyen $f:(a, b) \rightarrow \mathbb{R}$ konvex függvény. Ekkor

1. minden $x \in(a, b)$ mellett $f_{-}^{\prime}(x) \leq f_{+}^{\prime}(x)$;

2. minden $c, d \in(a, b)$ esetén, ha $c<d$, akkor $f_{+}^{\prime}(c) \leq \frac{f(d)-f(c)}{d-c} \leq f_{-}^{\prime}(d)$;

3. Az $f_{-}^{\prime}$ és az $f_{+}^{\prime}$ bal illetve jobb oldali derivált függvények monoton nönek;

4. Az $f_{-}^{\prime}$ bal oldali derivált függvény balról folytonos és az $f_{+}^{\prime}$ jobb oldali derivált függvény jobbról folytonos.

Ha feltesszük továbbá, hogy $f$ még szigorúan konvex is, akkor a fenti ii.) pontban $f_{+}^{\prime}(c)<\frac{f(d)-f(c)}{d-c}<f_{-}^{\prime}(d)$, és a iii.) pontbeli deriváltak szigorúan monoton nónek. 
Bizonyítás. Az elsô két pont nyilvánvaló következménye a definícióknak és a különbségi hányados függvény monotonitásának. Ha $c<d$ akkor az első két pont szerint

$$
f_{-}^{\prime}(c) \leq f_{+}^{\prime}(c) \leq \frac{f(d)-f(c)}{d-c} \leq f_{-}^{\prime}(d) \leq f_{+}^{\prime}(d) .
$$

Ez azt mutatja, hogy mind az $f_{-}^{\prime}$ és mind az $f_{+}^{\prime}$ függvény monoton növő.

Az utolsó állításhoz azt kell megmutatnunk, hogy $x<w, x \rightarrow w$ esetén $f_{-}^{\prime}(x) \rightarrow$ $f_{-}^{\prime}(w)$. Először is $\lim _{x \rightarrow w-} f_{-}^{\prime}(x)$ nyilvánvalóan létezik, hiszen minden $x<w$ esetén $f_{-}^{\prime}(x) \leq f_{-}^{\prime}(w)$ az $f_{-}^{\prime}$ bal oldali deriváltfüggvény monotonitása miatt. Ebből azt is látjuk, hogy

$$
\lim _{x \rightarrow w-} f_{-}^{\prime}(x) \leq f_{-}^{\prime}(w) .
$$

No de tetszőlegesen rögzített $y<w$ mellett:

$$
\frac{f(y)-f(w)}{y-w}=\lim _{x \rightarrow w-} \frac{f(y)-f(x)}{y-x} \leq \lim _{x \rightarrow w-} f_{-}^{\prime}(x)
$$

Eszerint

$$
f_{-}^{\prime}(w)=\sup \left\{\frac{f(y)-f(w)}{y-w}: y<w\right\} \leq \lim _{x \rightarrow w-} f_{-}^{\prime}(x)
$$

A jobb oldali derivált jobbról folytonosságához azt kell megmutatnunk, hogy $w<x$, $x \rightarrow w$ esetén $f_{+}^{\prime}(x) \rightarrow f_{+}^{\prime}(w)$. Először is $\lim _{x \rightarrow w+} f_{+}^{\prime}(x)$ nyilvánvalóan létezik, hiszen minden $w<x$ esetén $f_{+}^{\prime}(w) \leq f_{+}^{\prime}(x)$ az $f_{+}^{\prime}$ jobb oldali deriváltfüggvény monotonitása miatt. Ebből azt is látjuk, hogy

$$
\lim _{x \rightarrow w+} f_{+}^{\prime}(x) \geq f_{+}^{\prime}(w) .
$$

No de tetszőlegesen rögzített $w<y$ mellett:

$$
\frac{f(y)-f(w)}{y-w}=\lim _{x \rightarrow w+} \frac{f(y)-f(x)}{y-x} \geq \lim _{x \rightarrow w+} f_{+}^{\prime}(x) .
$$

Eszerint

$$
f_{+}^{\prime}(w)=\inf \left\{\frac{f(y)-f(w)}{y-w}: w<y\right\} \geq \lim _{x \rightarrow w+} f_{+}^{\prime}(x)
$$

Ezt kellett belátni.

A.10. állítás (konvex függvény differenciálhatósága). Legyen $f:(a, b) \rightarrow \mathbb{R}$ konvex függvény, és jelölje

$$
E=\{x \in(a, b): \text { f nem differenciálható } x-\text { ben }\}
$$

Ekkor az E halmaz legfeljebb megszámlálható, és az $f^{\prime}$ függvény folytonos is a $(a, b) \backslash$ E halmazon. 
Bizonyítás. Világos, hogy

$$
E=\left\{x \in(a, b): f_{-}^{\prime}(x)<f_{+}^{\prime}(x)\right\} .
$$

Ezért, ha $c, d \in E$ két különböző pont, akkor $c<d$ mellett

$$
f_{-}^{\prime}(c)<f_{+}^{\prime}(c) \leq f_{-}^{\prime}(d)<f_{+}^{\prime}(d) .
$$

Ez azt jelenti, hogy $\left(f_{-}^{\prime}(c), f_{+}^{\prime}(c)\right)$ valamint $\left(f_{-}^{\prime}(d), f_{+}^{\prime}(d)\right)$ nem üres diszjunkt nyílt intervallumok. Világos, hogy nem üres diszjunkt nyílt intervallum csak annyi lehet a számegyenesen, ahány racionális szám van. Így az $E$ halmaz számossága legfeljebb megszámlálható.

Tekintsük az $f^{\prime}=f_{-}^{\prime}=f_{+}^{\prime}$ függvényt, amelynek értelmezési tartománya $(a, b) \backslash E$. Világos, hogy ez mind balról mind jobbról is folytonos, ezért folytonos.

A.11. állítás. Legyen $f:(a, b) \rightarrow \mathbb{R}$ konvex függvény. Ekkor minden $[c, x] \subseteq(a, b)$ mellett

$$
f(x)=f(c)+\int_{c}^{x} f_{-}^{\prime}(t) d t=f(c)+\int_{c}^{x} f_{+}^{\prime}(t) d t
$$

Emiatt persze tetszóleges olyan $h:(a, b) \rightarrow \mathbb{R}$ függvényre, amelyre $f_{-}^{\prime} \leq h \leq f_{+}^{\prime}$ teljesül, a h monoton növó emiatt Riemann-integrálható, és fennáll az.

$$
f(x)=f(c)+\int_{c}^{x} h(t) d t
$$

egyenlöség.

Bizonyítás. Mivel az $f_{-}^{\prime}$ és az $f_{+}^{\prime}$ függvények monoton nőnek a $[c, x]$ korlátos és zárt intervallum felett, ezért $\int_{c}^{x} f_{-}^{\prime}$ és $\int_{c}^{x} f_{+}^{\prime}$ Riemann-integrálok léteznek.

Legyen $I \in \mathscr{D}[c, x], I=\left\{c=x_{0}<x_{1}<\ldots<x_{n-1}<x_{n}=x\right\}$ egy felosztás. Ekkor az $f$ konvexitása szerint minden $k$ index mellett

$$
f_{+}^{\prime}\left(x_{k-1}\right) \leq \frac{f\left(x_{k}\right)-f\left(x_{k-1}\right)}{x_{k}-x_{k-1}} \leq f_{-}^{\prime}\left(x_{k}\right),
$$

vagy ami evvel ekvivalens

$$
f_{+}^{\prime}\left(x_{k-1}\right)\left(x_{k}-x_{k-1}\right) \leq f\left(x_{k}\right)-f\left(x_{k-1}\right) \leq f_{-}^{\prime}\left(x_{k}\right)\left(x_{k}-x_{k-1}\right) .
$$

Összeadva azt kapjuk, hogy

$$
\sum_{k=1}^{n} f_{+}^{\prime}\left(x_{k-1}\right)\left(x_{k}-x_{k-1}\right) \leq f(x)-f(c) \leq \sum_{k=1}^{n} f_{-}^{\prime}\left(x_{k}\right)\left(x_{k}-x_{k-1}\right) .
$$

Vegyük észre, hogy az $f_{+}^{\prime}$ és $f_{-}^{\prime}$ függvények monoton növekedő volta miatt a bal oldali összeg egy alsó közelítő összeg és a jobb oldali szumma egy felső közelítő összeg. Pontosabban

$$
s\left(f_{+}^{\prime}, I\right) \leq f(x)-f(c) \leq S\left(f_{-}^{\prime}, I\right) .
$$


Ez minden $I$ felosztásra igaz, ezért

$$
\int_{c}^{x} f_{+}^{\prime} \leq f(x)-f(c) \leq \int_{c}^{x} f_{-}^{\prime} \leq \int_{c}^{x} f_{+}^{\prime}
$$

A fenti sor egyenlőtlenségeit, tehát egyenlőségre is cserélhetjük. Ezt kellett belátni.

A.12. állítás. Legyen $f:(a, b) \rightarrow \mathbb{R}$ egy differenciálható függvény. Az $f$ pontosan akkor konvex, ha $f^{\prime}$ függvény monoton növó.

Bizonyítás. Amennyiben $f$ konvex, akkor láttuk, hogy $f^{\prime}=f_{-}^{\prime}$ függvény monoton növő.

Megfordítva, ha $f^{\prime}$ függvény monoton növô, akkor minden $[c, x] \subseteq(a, b)$ korlátos és zárt intervallumon Riemann-integrálható, és $f$ egy olyan a $(c, x)$ intervallum minden pontjában differenciálható függvény, melynek deriváltfüggvénye $f^{\prime}$ és $f$ még folytonos is $c$ és $b$ pontokban. Alkalmazhatjuk tehát $f^{\prime}$-ra a Newton-Leibniz-tételt. Így

$$
f(x)=f(c)+\int_{c}^{x} f^{\prime},
$$

ami azt jelenti, hogy $f$ egy monoton növő függvény integrálfüggvénye egy additív konstanstól eltekintve. Láttuk, hogy ez esetben $f$ konvex.

A.13. álítás. Legyen $f:(a, b) \rightarrow \mathbb{R}$ egy differenciálható függvény. Az $f$ pontosan akkor szigorúan konvex, ha f' függvény szigorúan monoton növö.

A.14. állítás. Legyen $f:(a, b) \rightarrow \mathbb{R}$ egy kétszer differenciálható függvény. Az $f$ pontosan akkor konvex, ha $f^{\prime \prime} \geq 0$.

A.15. állítás. Legyen $f:(a, b) \rightarrow \mathbb{R}$ egy kétszer differenciálható függvény. $H a f^{\prime \prime}>0$, akkor $f$ szigorúan konvex.

\section{A.2. Támaszegyenesek}

A.16. definíció (támaszfüggvény). Legyen $f: I \rightarrow \mathbb{R}$ egy intervallumon értelmezett függvény, $x_{0} \in I$ rögzített. Az

$$
A_{m, x_{0}}(x)=f\left(x_{0}\right)+m\left(x-x_{0}\right)
$$

függvényt az $f$ függvény $x_{0}$ pontbeli $m$ meredekségú támaszfüggvényének nevezzük, ha minden $x \in I$ mellett

$$
f(x) \geq A_{m, x_{0}}(x) .
$$

A.17. állítás. Legyen $f: I \rightarrow \mathbb{R}$ egy intervallumon értelmezett függvény, $x_{0} \in I$ rögzített. Az alábbi feltételek tetszóleges $m \in \mathbb{R}$ valós számra ekvivalensek: 
1. Minden $u<x_{0}<v ; u, v \in I$ esetén $\frac{f(u)-f\left(x_{0}\right)}{u-x_{0}} \leq m \leq \frac{f(v)-f\left(x_{0}\right)}{v-x_{0}}$,

2. Minden $x \in$ I mellett $f(x) \geq f\left(x_{0}\right)+m\left(x-x_{0}\right)=A_{m, x_{0}}(x)$.

A.18. állítás. Legyen $f: I \rightarrow \mathbb{R}$ egy intervallumon értelmezett konvex függvény, $x_{0} \in I$ belsố pont rögzített. Az alábbi feltételek tetszóleges $m \in \mathbb{R}$ valós számra ekvivalensek:

1. $f_{-}^{\prime}\left(x_{0}\right) \leq m \leq f_{+}^{\prime}\left(x_{0}\right)$

2. Minden $x \in I$ mellett $f(x) \geq f\left(x_{0}\right)+m\left(x-x_{0}\right)=A_{m, x_{0}}(x)$.

Bizonyítás. Az $f$ konvexitása szerint a $f_{-}^{\prime}\left(x_{0}\right)$ szám az $\frac{f(u)-f\left(x_{0}\right)}{u-x_{0}}$ alakú számok legkisebb felsô korlátja, ahol $u<x_{0}$ és az $f_{+}^{\prime}\left(x_{0}\right)$ szám az $\frac{f(v)-f\left(x_{0}\right)}{v-x_{0}}$ alakú számok legnagyobb alsó korlátja, ahol $v>x_{0}$. Ez azt jelenti, hogy az itteni $i$ feltétel ekvivalens az előző állítás $i$ feltételével.

A.19. állítás. Legyen $f: I \rightarrow \mathbb{R}$ egy intervallumon értelmezett függvény. Az $f$ pontosan akkor konvex, ha az értelmezési tartománya minden belsó pontjában van támaszfüggvénye.

Bizonyítás. Ha $f$ konvex, akkor láttuk, hogy $f_{-}^{\prime}\left(x_{0}\right) \leq f_{+}^{\prime}\left(x_{0}\right)$ az értelmezési tartomány minden $x_{0}$ belsố pontjában, teljesül tehát az előző állítás $i$ pontja, ami azt jelenti, hogy tetszólegesen választott $f_{-}^{\prime}\left(x_{0}\right) \leq m \leq f_{+}^{\prime}\left(x_{0}\right)$ szám mellett $A_{m, x_{0}}$ egy támaszfüggvénye $f$-nek az $x_{0}$ pontban.

Ha minden pontban van az $f$ függvénynek támaszfüggvénye, akkor tetszőleges $u<$ $x_{0}<v$ esetén $F_{x_{0}}(u) \leq F_{x_{0}}(v)$. Láttuk, hogy egyszerú algebrai átalakításokkal ez

$$
f\left(x_{0}\right) \leq \frac{v-x_{0}}{v-u} f(u)+\frac{x_{0}-u}{v-u} f(v)
$$

alakba írható. Mivel ez minden $u<x_{0}<v$ hármasra fennáll, ez éppen $f$ konvexitásának definíciója az I intervallumon.

A.20. állítás (konvex függvény differenciálhatósága). Legyen $f: I \rightarrow \mathbb{R}$ egy intervallumon értelmezett konvex függvény. Az f pontosan akkor differenciálható az értelmezési tartománya egy belsó pontjában, ha egy ilyen pontban csak egyetlen támaszfüggvénye van.

Bizonyítás. Tudjuk, hogy egy konvex függvény pontosan akkor differenciálható az értelmezési tartománya $x_{0}$ belsố pontjában, ha a bal és jobb oldali deriváltja egybeesik. Ez úgy is fogalmazható, hogy csak egyetlen egy $m$ szám írható a bal és jobb oldali deriváltak közé, azaz ha csak egyetlen egy támaszegyenese van az $x_{0}$ pontban. 
IRODALOMJEGYZÉK 
[1] Jeremy Bulow and Paul Klemperer. Rational frenzies and crashes. Journal of Political Economy, 102(1):1-23, 1994. URL: http://www.jstor.org/stable/ 2138791

[2] Vick M. Coppinger, Vernon L. Smith, and Jon A. Titus. Incentives and behavior in english, dutch and sealed-bid auctions. Economic Inquiry, 18(1):1-22, 1980. doi:10.1111/j.1465-7295.1980.tb00556.x

[3] James Cox, Bruce Roberson, and Vernon Smith. Theory and Behavior of Single Object Auctions, volume 2. Greenwich: JAI Press, 011982.

[4] Csekő Imre. Rövid bevezetés az egyensúly elméletébe. Budapesti Corvinus Egyetem, Budapest, 2016. URL: http://unipub.lib.uni-corvinus.hu/2668

[5] Dancs István, Magyarkuti Gyula és Medvegyev Péter. Bevezetés a matematika analízisbe. Aula Kvk., 1995. URL:http://mek.oszk.hu/00800/00855

[6] Benjamin Edelman, Michael Ostrovsky, and Michael Schwarz. Internet advertising and the generalized second-price auction: Selling billions of dollars worth of keywords. American Economic Review, 97(1):242-259, March 2007. URL: http://www.aeaweb.org/articles?id=10.1257/aer.97.1.242 doi:10. 1257/aer.97.1.242

[7] Maxim Engers and Brian McManus. Charity auctions. International Economic Review, 48(3):953-994, 2007. doi:10.1111/j.1468-2354.2007.00451.x

[8] Emel Filiz-Ozbay and Erkut Y. Ozbay. Auctions with anticipated regret: Theory and experiment. American Economic Review, 97(4):1407-1418, September 2007. URL: http://www .aeaweb.org/articles?id=10.1257/aer.97.4. 1407 doi: 10.1257/aer.97.4.1407

[9] Jacob K. Goeree and Theo Offerman. The amsterdam auction. Econometrica, 72(1):281-294, 2004. URL: http://www . jstor .org/stable/3598856

[10] Jacob K. Goeree, Charles R. Plott, and John Wooders. Bidders' choice auctions: Raising revenues through the right to choose. Journal of the European Economic Association, 2(2-3):504-515, 2004. doi : 10.1162/154247604323068186

[11] Jacob K. Goeree, Emiel Maasland, Sander Onderstal, and John L. Turner. How (not) to raise money. Journal of Political Economy, 113(4):897-918, 2005. doi : $10.1086 / 431288$

[12] Werner Güth and Radosveta Ivanova-Stenzel. Asymmetric auction experiments with(out) commonly known beliefs. Papers on strategic interaction, Max Planck Institute of Economics, Strategic Interaction Group, 2003. URL: https:// EconPapers .repec . org/RePEc : esi : discus : 2002-36. 
[13] Werner Güth, Radosveta Ivanova-Stenzel, and Elmar Wolfstetter. Bidding behavior in asymmetric auctions: An experimental study. European Economic Review, 49(7):1891 - 1913, $2005 . \quad$ URL: http: //www.sciencedirect.com/science/article/pii/S0014292104000753. doi:10.1016/j.euroecorev.2004.09.003

[14] Isa Hafalir and Vijay Krishna. Asymmetric auctions with resale. American Economic Review, 98(1):87-112, 2008. URL: https : //EconPapers .repec .org/ RePEc :aea:aecrev:v:98:y:2008: i:1:p:87-112.

[15] Kenneth Hendricks and Robert Porter. An empirical study of an auction with asymmetric information. American Economic Review, 78(5):865-83, 1988. URL: https://EconPapers.repec .org/RePEc : aea:aecrev: v:78: $\mathrm{y}: 1988: \mathrm{i}: 5: \mathrm{p}: 865-83$

[16] Kenneth Hendricks and Robert Porter. Collusion in Auctions. Discussion Papers 817, Northwestern University, Center for Mathematical Studies in Economics and Management Science, January 1989. URL: https://ideas.repec.org/p/ nwu/cmsems/817.html

[17] Radosveta Ivanova-Stenzel and Doron Sonsino. Comparative study of onebid versus two-bid auctions. Journal of Economic Behavior \& Organization, 54(4):561 - 583, 2004. URL: http://www.sciencedirect.com/science/ article/pii/S0167268103001574, doi:10.1016/j.jebo.2002.11.002

[18] Paul Klemperer. Auctions: Theory and Practice. Princeton University Press, 2004. URL: https://press.princeton.edu/titles/7728.html

[19] Vijay Krishna. Auction Theory. Elsevier, 1 edition, 2002. URL: https: //EconPapers.repec.org/RePEc:eee:monogr:9780124262973 doi:10. 1016/B978-0-12-374507-1.00050-9

[20] Vijay Krishna and Motty Perry. Efficient Mechanism Design. Game Theory and Information 9703010, University Library of Munich, Germany, March 1997. URL: https: //ideas.repec.org/p/wpa/wuwpga/9703010.html

[21] Jonathan Levin. Wars of attrition. Technical report, Oct 2004. URL: https : //web.stanf ord.edu/ jdlevin/Econ\%20286/Wars $\% 20$ of $\%$ 20Attrition.pdf

[22] David Lucking-Reiley. Using field experiments to test equivalence between auction formats: Magic on the internet. The American Economic Review, 89(5):10631080, 1999. URL: http://www.jstor.org/stable/117047

[23] Magyarkuti Gyula. Mértékelmélet és dinamikus programozás. TypoTeX Kiadó, ISBN 978-963-279-254-5., 2014. URL: https : //www . tankonyvtar .hu 
[24] Robert C. Marshall and Leslie M. Marx. Bidder collusion. Journal of Economic Theory, 133(1):374 - 402, 2007. URL:http://www.sciencedirect.com/ science/article/pii/S0022053105002784 doi:10.1016/j.jet.2005. 12.004

[25] Andreu Mas-Colell, Michael Whinston, and Jerry Green. Microeconomic Theory. Oxford University Press, 1995. URL: https ://EconPapers.repec.org/ RePEc: oxp : obooks: 9780195102680

[26] Steven A. Matthews. A Technical Primer on Auction Theory I: Independent Private Values. Discussion Papers 1096, Northwestern University, Center for Mathematical Studies in Economics and Management Science, May 1995. URL: https://ideas.repec.org/p/nwu/cmsems/1096.html

[27] Medvegyev Péter. Bevezetés a valószínüségszámításba. Budapesti Corvinus Egyetem, Budapest ISBN 978-963-503-647-9, 2017. URL: http://unipub. lib.uni-corvinus.hu/3088/

[28] Flavio Menezes and Paulo K. Monteiro. An Introduction to Auction Theory. Oxford University Press, 2004. URL: https ://doi .org/10.1093/019927598X . 001.0001

[29] Paul Milgrom. Putting Auction Theory to Work. Churchill Lectures in Economics. Cambridge University Press, 2004. doi : 10.1017/CB09780511813825

[30] Paul Milgrom. Simplified mechanisms with an application to sponsored-search auctions. Games and Economic Behavior, 70(1):62 - 70, 2010. Special Issue In Honor of Ehud Kalai. URL: http://www .sciencedirect.com/science/ article/pii/S0899825608002212, doi:10.1016/j.geb.2008.12.003

[31] Paul R. Milgrom and Robert J. Weber. A theory of auctions and competitive bidding. Econometrica, 50(5):1089-1122, 1982. URL: http://www.jstor. org/stable/1911865

[32] John Morgan. Financing public goods by means of lotteries. The Review of Economic Studies, 67(4):761-784, 2000. URL: http://dx.doi.org/10.1111/ 1467-937X.00153 doi:10.1111/1467-937X.00153

[33] John Morgan, Ken Steiglitz, and George Reis. The spite motive and equilibrium behavior in auctions. Contributions in Economic Analysis \& Policy, 2003. URL: https://www.degruyter.com/view/j/be jeap.2002.2. issue-1/be jeap.2003.2.1.1102/be jeap.2003.2.1.1102.xml, doi:10. 2202/1538-0645.1102,

[34] Roger B. Myerson. Optimal Auction Design. Discussion Papers 362, Northwestern University, Center for Mathematical Studies in Economics and Management Science, December 1978. URL: https://ideas .repec .org/p/nwu/cmsems/ 362.html 
[35] Roger B Myerson and Mark A Satterthwaite. Efficient mechanisms for bilateral trading. Journal of Economic Theory, 29(2):265 - 281, 1983. URL: http: //www.sciencedirect.com/science/article/pii/0022053183900480. doi:https://doi.org/10.1016/0022-0531(83)90048-0

[36] Naoko Nishimura, Timothy N. Cason, Tatsuyoshi Saijo, and Yoshikazu Ikeda. Spite and counter-spite in auctions. mimeo, Purdue University, 2005.

[37] Paul Pezanis-Christou and Abdolkarim Sadrieh. Elicited bid functions in (a)symmetric first-price auctions. Working Papers 85, Barcelona Graduate School of Economics, June 2003. URL: https : //ideas . repec . org/p/bge/wpaper/ 85.html.

[38] Michael Rothschild and Joseph E Stiglitz. Increasing risk: I. a definition. Journal of Economic Theory, 2(3):225 - 243, 1970. URL: http://www . sciencedirect.com/science/article/pii/0022053170900384 doi:10. 1016/0022-0531(70) 90038-4

[39] Nicolas Treich and Olivier Armantier. Subjective probabilities in games: an application to the overbidding puzzle. International Economic Review, 50(4):10791102, 112009.

[40] Hal Varian. Position auctions. International Journal of Industrial Organization, 25(6):1163-1178, 2007. URL: https://EconPapers .repec .org/RePEc: eee: indorg: $v: 25: y: 2007: i: 6: p: 1163-1178$.

[41] Hal R. Varian. Mikroökonómia középfokon, Egy modern megközelítés. Akadémiai Kiadó Rt., Budapest, 2008. 


\section{TÁRGYMUTATÓ}

allokáció függvény, 84

angol aukció, 11

befizetési függvény, 84

bevételekvivalencia-elv, 51 54, 56

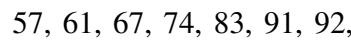

\begin{tabular}{l|l|l|l|l|l|}
\hline 94 & 96 & 102 & 105 \\
\hline
\end{tabular}

direkt-mechanizmus, 87

egy oldali derivált függvény, 127

egyénileg racionális, 101

egyensúlyi hasznosság, 92

egyensúlyi stratégia, 86

elsőáras aukció, 12, $14,15,25,27,29$

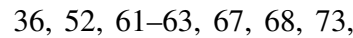

97106

ex ante várhatató befizetés, 22

ex post várható befizetés, 22

harmadáras aukció, 55, 57

hatékony

allokáció, 112

aukció, 67,109

mechanizmus, 109

holland aukció, 12

igazmondás stratégia, 86

jóléti függvény, 112

kivéreztetés aukció, 54

kockázat, 21, 61

kockázatelutasító,29 kockázati ráta, 4143

kockázatkedvelő,29

kockázatkerülő, 61 62

kockázatsemleges, 29,61

konvex függvény, 46,93 94 $94,125,128$

liciteloszlás, 68

másodáras aukció, 12, 15, 16, 19,21

25. 28, $29,33,35,41,43$

44, $47,52,55,61,73,74$

97, 106,119

mechanizmus, 84

megvalósítható mechanizmus, 102

mindenki fizet aukció,53

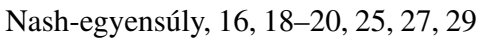

\begin{tabular}{lllllll}
36 & 37 & 51 & 67 & 68 & 74 & 78 \\
\hline
\end{tabular}

$7983 \quad 86 \quad 88$

Neumann-Morgenstern-hasznosság, 61

nyertes, 15

nyertes fizet, 18

nyertes fizet típusú aukció, 15

optimális megvalósítható mechanizmus, 102

ösztönző mechanizmus, 91

reguláris játékos, 45, 46,97

rezervációs ár, 11, 15 33, 36, $41,43$.

47 $84 \quad 106$

standard aukció, 15, $18,$\begin{tabular}{l|l|l|l|}
19 & 25 & 33 & 35 \\
\hline
\end{tabular}

51 
stratégia, 86

szignál halmaz, 84

sztochasztikus dominancia, 77

támaszfüggvény, 92,93 130 131

várható befizetés, 17, 18, 21, 22, 28.

37, $41,43,47,51,56,85$

VCG-befizetési szabály, 113

vesztesek fizetnek aukció, 54

virtuális értékelés, 45, 46, 83, 96, 97.

$101,104,106$ 


\section{Aukcióelmélet előadások}

A vevő és az eladó közti egyezség megteremtésére kézenfekvő ötlet valamilyen aukció szervezése. A gondolat messze nem új. Az ókori babilóniaiak, görögök, de a Római Birodalom polgárai is hatalmas tranzakciókat bonyolítottak aukciók segítségével. Manapság így értékesítenek mobil telefon frekvenciákat, olajmezőket, de Németországban az egyes kis szélerőmü tulajdonosok is aukció keretében adják el az általuk megtermelt megújuló energiát. Sokfajta aukció képzelhető el.

A nyertes fizetheti a legnagyobb licitet, a második (harmadik stb.) legnagyobb licitet, de még az is elképzelhető, hogy minden résztvevő fizet és csak a legnagyobb licitet adó nyer. Milyen aukció mechanizmus adja a lehető legnagyobb bevételt? Garantálható-e, hogy a nyertes az legyen, akinek számára az áru birtoklása a legnagyobb hatékonyságot jelenti? Mi van, ha rezervációs árat vezetünk be, vagy mit jelent a kockázatok preferálása?

Ezekre a kérdésekre kell legelőször választ keresnünk ahhoz, hogy megérthessük a modern aukcióelmélet rejtelmeit. 